\title{
NGNP Data Management and Analysis System Analysis and Web Delivery Capabilities
}

C. D. Gentillon

M. L. Abbott

L. C. Hull

N. J. Lybeck

B. T. Pham

September 2011
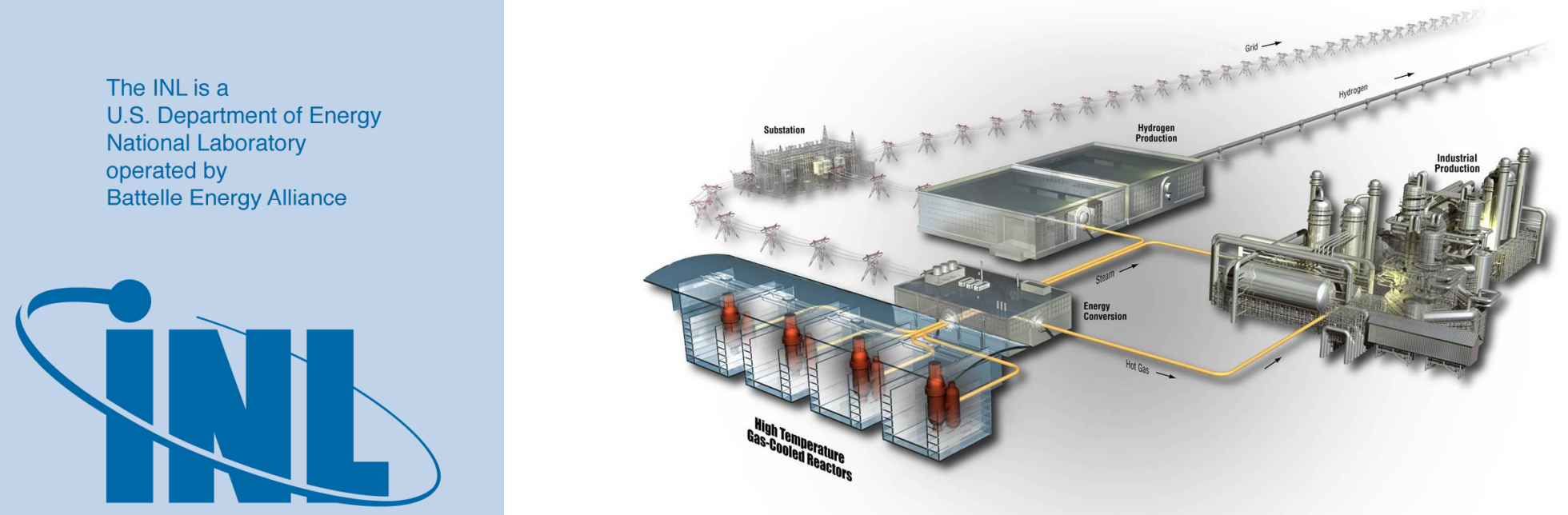

Idaho National Laboratory 


\section{DISCLAIMER}

This information was prepared as an account of work sponsored by an agency of the U.S. Government. Neither the U.S. Government nor any agency thereof, nor any of their employees, makes any warranty, expressed or implied, or assumes any legal liability or responsibility for the accuracy, completeness, or usefulness, of any information, apparatus, product, or process disclosed, or represents that its use would not infringe privately owned rights. References herein to any specific commercial product, process, or service by trade name, trade mark, manufacturer, or otherwise, does not necessarily constitute or imply its endorsement, recommendation, or favoring by the U.S. Government or any agency thereof. The views and opinions of authors expressed herein do not necessarily state or reflect those of the U.S. Government or any agency thereof. 
INL/EXT-09-16327

Revision 2

\title{
NGNP Data Management and Analysis System Analysis and Web Delivery Capabilities
}

\author{
C. D. Gentillon \\ M. L. Abbott \\ L. C. Hull \\ N. J. Lybeck \\ B. T. Pham
}

September 2011

Idaho National Laboratory

Next Generation Nuclear Plant Project

Idaho Falls, Idaho 83415

Prepared for the

U.S. Department of Energy

Office of Nuclear Energy

Under DOE Idaho Operations Office

Contract DE-AC07-05ID14517 

Next Generation Nuclear Plant Project

\section{NGNP Data Management and Analysis System Analysis and Web Delivery Capabilities}

INL/EXT-09-16327

Revision 2

September 2011

Approved by:


Cynthia D. Gentillon

NDMAS Modeling and Analysis Lead

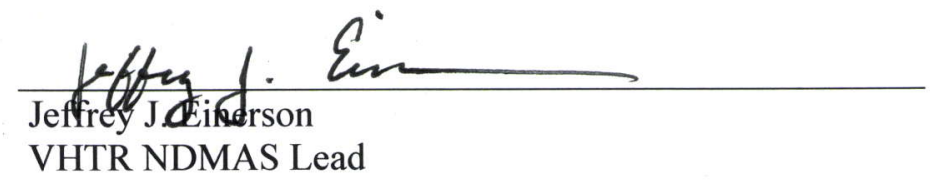

Tack Alninds Diane V.Croson

VHTR TDO Deputy Director

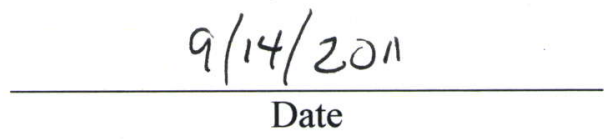

$\frac{9-14-11}{\text { Date }}$

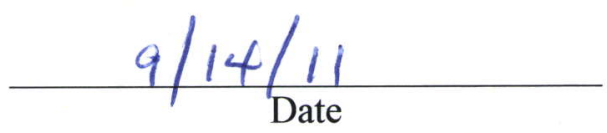





\begin{abstract}
Activities for the Very High Temperature Reactor (VHTR) Technology Development Office (TDO) provide data in support of Nuclear Regulatory Commission (NRC) licensing of the Next Generation Nuclear Plant (NGNP). Fuel and materials to be used in the NGNP reactor are tested and characterized to quantify performance in high-temperature and high-fluence environments. The NGNP Data Management and Analysis System (NDMAS) at the Idaho National Laboratory has been established to ensure that VHTR data are (1) qualified for use, (2) stored in a readily accessible electronic form, and (3) analyzed to extract useful results.

This document focuses on the third NDMAS objective. It describes capabilities for displaying the data in meaningful ways and for data analysis to identify useful relationships among the measured quantities. The capabilities are described from the perspective of NDMAS users, starting with those who just view experimental data and analytical results on the INL NDMAS web portal. Web display and delivery capabilities are described in detail. Also the current web pages that show Advanced Gas Reactor, Advanced Graphite Creep, and High Temperature Materials test results are itemized. Capabilities available to NDMAS developers are more extensive, and are described using a second series of examples. Much of the data analysis efforts focus on understanding how thermocouple measurements relate to calculated temperatures and other experimental parameters. Statistical control charts and correlation monitoring provide an ongoing assessment of instrument accuracy. Data analysis capabilities are virtually unlimited for those who use the NDMAS web data download capabilities and the analysis software of their choice.
\end{abstract}

Overall, the NDMAS provides convenient data analysis and web delivery capabilities for studying a very large and rapidly increasing database of welldocumented, pedigreed data. 


\section{SUMMARY}

Projects for the Very High Temperature Reactor Technology Development Office (VHTR-TDO) provide data in support of Nuclear Regulatory Commission licensing of the Next Generation Nuclear Plant (NGNP). Fuel and materials to be used in the reactor are tested and characterized to quantify performance in hightemperature and high-fluence environments. Thermal-hydraulic experiments are also conducted to validate codes used to assess reactor safety. The VHTR Program has established the NGNP Data Management and Analysis System (NDMAS) to ensure that VHTR data are (1) qualified for use, (2) stored in a readily accessible electronic form, and (3) analyzed to extract useful results.

This document focuses on the third NDMAS objective. It describes capabilities for displaying the data in meaningful ways and identifying relationships among the measured quantities that contribute to their understanding. The capabilities are described from the perspective of NDMAS users, starting with those who just view experimental data and analytical results on the Idaho National Laboratory (INL) NDMAS web portal. Table S-1 provides an overview of the web page display and analysis capabilities.

Table S-1. Data analysis, display, and delivery capabilities in NDMAS web pages.

\begin{tabular}{|c|c|c|c|c|c|c|c|}
\hline \multirow[b]{2}{*}{ Web Page ${ }^{a}$} & \multicolumn{7}{|c|}{ Capabilities } \\
\hline & 量 &  & $\frac{\bar{z}}{\tilde{\Xi}}$ & 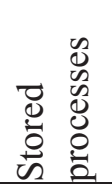 &  &  &  \\
\hline AGC-1 $\rightarrow$ CHR & $\mathrm{X}$ & - & $\mathrm{X}$ & - & $\mathrm{X}$ & $\mathrm{X}$ & $\mathrm{X}$ \\
\hline AGC-1 $\rightarrow$ IRR, AGC-2 $\rightarrow$ IRR & $\mathrm{X}$ & - & $\mathrm{X}$ & - & - & $\mathrm{X}$ & $\mathrm{X}$ \\
\hline AGR-1 $\rightarrow$ Home, AGR-2 $\rightarrow$ Home & $\mathrm{X}$ & $\mathrm{X}$ & - & - & - & - & - \\
\hline AGR-1 $\rightarrow$ FAB & $\mathrm{X}$ & - & - & - & - & - & - \\
\hline AGR-2 $\rightarrow$ FAB & $\mathrm{X}$ & - & $\mathrm{X}$ & - & - & - & $\mathrm{X}$ \\
\hline AGR-1 $\rightarrow$ FPM, AGR-2 $\rightarrow$ FPM & $\mathrm{X}$ & $\mathrm{X}$ & - & - & $\mathrm{X}$ & - & $\mathrm{X}$ \\
\hline AGR-1 $\rightarrow$ GG, AGR-2 $\rightarrow$ GG & $\mathrm{X}$ & - & - & $\mathrm{X}$ & - & - & - \\
\hline AGR-1 $\rightarrow$ IRR, AGR-2 $\rightarrow$ IRR & $\mathrm{X}$ & - & $\mathrm{X}$ & - & - & - & $\mathrm{X}$ \\
\hline AGR-1 $\rightarrow$ PHY & $\mathrm{X}$ & - & - & - & - & - & $\mathrm{X}$ \\
\hline $\begin{array}{l}\text { AGR- } 1 \rightarrow \text { Analysis, AGR-2 } \\
\rightarrow \text { Analysis } \rightarrow \text { Temperatures }\end{array}$ & $\mathrm{X}$ & $\mathrm{X}$ & - & - & $\mathrm{X}$ & - & - \\
\hline AGR-2 $\rightarrow$ Analysis $\rightarrow$ Gas Flows & $X$ & $\mathrm{X}$ & - & - & $\mathrm{X}$ & - & - \\
\hline HTM $\rightarrow$ Creep Tests & $\mathrm{X}$ & - & - & $X$ & - & - & $X$ \\
\hline HTM $\rightarrow$ Cyclic Tests & $\mathrm{X}$ & $\mathrm{X}$ & - & $\mathrm{X}$ & - & - & $\mathrm{X}$ \\
\hline HTM $\rightarrow$ Tensile Tests & $\mathrm{X}$ & $\mathrm{X}$ & - & $\mathrm{X}$ & - & - & $\mathrm{X}$ \\
\hline
\end{tabular}


Most of the capabilities identified in Table S-1 are self-explanatory. Lattice graphs are graphs with panels that show the data for different groupings, such as different Advanced Gas Reactor-1 (AGR-1) fuel irradiation experiment capsules. Tabular drill-downs allow the data to be expanded or contracted for different levels of detail in the data display, with all graphs and tables in that display linked to respond accordingly. Selecting different time spans for viewing the data is one example of a level of detail that can be changed. Stored processes perform calculations and access data on a real-time basis, so that the information is always current. Boxplots and histograms are forms of graphs that show the distributions of data. ActiveX graphs are dynamic, high-resolution, web figures that allow on-the-fly alteration, such as rescaling of axes, subsetting of data, and viewing data values associated with each point. Data downloads to easilyimported text files are available by clicking on an icon at the top of the tabular drilldown or by clicking on download links. Together, these capabilities allow the user to view the data and perform data analysis.

The report provides a detailed description of each item in the web pages listed in Table S-1, with references to the analysis and web display and delivery capabilities that they provide. New web pages continue to be developed; the current descriptions apply as of September 2011.

Capabilities available to NDMAS developers are more extensive because the full power of the SAS Institute, Inc. statistical and analysis software, which supports much of the system, is available. A series of examples further illustrate the current capabilities.

Much of the modeling effort focused on understanding the AGR-1 fuel irradiation experiment temperature measurements. The temperatures are driven by Advanced Test Reactor operating conditions such as control-cylinder and regulating-rod positions that modulate the neutron flux to the fuel compacts in the experiment test train. The AGR-1 control system adjusts the mixture and flow of neon and helium for each capsule in the experiment test train in order to maintain capsule temperatures in a predefined target range. The gas flow adjustments provide a temperature control function because helium conducts heat away from the fuel capsules at a much faster rate than neon.

The control gas system needs accurate temperature feedback in order to stabilize the temperatures at desired levels. However, nine of 18 thermocouples (TCs) installed in the AGR-1 fuel irradiation experiment are known to have failed during the experiment that began in late 2006. A process for ongoing assessments of TC performance has been added in the NDMAS data review (using statistical control charts and correlation monitoring) to help detect TC problems if they arise in the currently-running AGR-2 and Advanced Graphite Creep 2 (AGC-2) irradiation experiments.

For the AGR-2 experiment, two new issues have developed that are being addressed in part by the analysis of data in NDMAS. One is to estimate the HeNe mixture for the capsules in the test train that have lost all TC measurements, using current data from capsules with working TCs and relationships developed between the gas flows and temperatures before the other TCs were lost. The second issue deals with the effect of potential leakage of leadout gases into the capsules. Such leakage may change the effective neon fraction in those capsules. 
Although the AGR-1 experiment is completed, study of its results continues. Physics-based neutronic and thermal analysis codes have generated simulated estimates of most of the irradiation parameters. The simulated estimates include parameters such as fission power in the fuel and in the graphite that cannot be directly measured in the experiment. These simulated estimates are also stored in NDMAS. Comparisons of the measured and simulated data lead to additional data analyses. It is possible that some of the TCs that were not declared to be failed in the AGR-1 experiment experienced drift. Studies of differences and possible anomalies in the measured and simulated data are briefly described. There is much to be gained from considering how the many attributes interact in the complex and challenging environment of these experiments.

In addition to data analysis and web display capabilities for NDMAS developers, a third set of analysis capabilities applies to researchers who download data from NDMAS. The web delivery of data to users leads to virtually unlimited data analysis capabilities, since users can apply their own analysis tools or software.

The data analysis and web page creation by NDMAS developers is an ongoing effort. Ideas for extensions of existing analyses and displays are listed. As additional data sets enter NDMAS, still more opportunities for data analysis and web delivery arise. In summary, the NDMAS provides a wide array of capabilities through the INL-NDMAS web portal, interaction with the NDMAS staff, and direct use of downloaded data. 


\section{FOREWORD}

This document is the second annual update of the Next Generation Nuclear Plant (NGNP) Data Management and Analysis System (NDMAS) modeling capabilities report originally published in September 2009 and updated in September 2010. This report follows the same basic pattern as the previous reports. The update includes recent analysis and web display/delivery activities. These activities spring from the following changes that have occurred in the last year to the NDMAS:

- More data has accrued:

- Post-irradiation examination (PIE) data from AGR-1, such as the metrology data, have been input.

- A web page has been developed that shows some aspects of the life cycle of the AGR-1 compacts, from fabrication through irradiation and the sizing data from PIE. The display shows the changes based on the position of each compact in the test train.

- Advanced Gas Reactor (AGR) Test 2 (AGR-2) fabrication data have been added.

- AGC-1 data have been refreshed, and some AGC-2 data have been added although the AGC-2 characterization data are not yet available.

- Ongoing measured data from the AGR-2 and AGC-2 irradiation experiments continue to be input to NDMAS.

- Data from several High Temperature Materials (HTM) experiments have been added, along with web pages that show the results.

- The NDMAS website hierarchical layout has continued to evolve and support the experiments and data streams within the NGNP projects and major tests. The system now uses the SAS Information Delivery Portal 4.3, SAS Foundation 9.2, SAS Web Report Studio 9.2, SAS Enterprise Guide 4.3 and SAS JMP Version 8. The data structures are NDMAS Version 1.1.

In response to these enhancements to NDMAS, the application of analysis and web delivery capabilities has expanded to cover the additional data streams.

Like the previous document, this report is self-contained. The largest section is a description of web display capabilities and an appendix with descriptions of analyses currently featured on various web pages. Additional data analysis beyond the web page displays includes use of control charts to monitor thermocouple performance and use of calculated and measured data to study possible anomalies in the data. The capability in the SAS JMP software for observing the effects of modeling choices is illustrated. 


\section{ACKNOWLEDGEMENTS}

In addition to the authors of this report, many NDMAS team members contributed to the web pages that show many of the modeling capabilities discussed herein, including:

Jeffrey J. Einerson

Keith Daum

Gordon Bower

Review comments from Diane Croson and Jack Simonds have increased the clarity of this report. Jodi Vollmer's support is gratefully acknowledged. 


\section{CONTENTS}

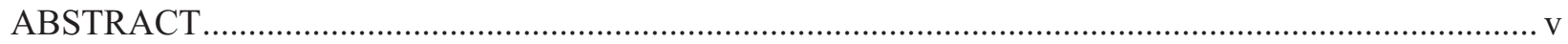

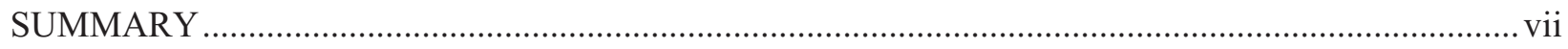

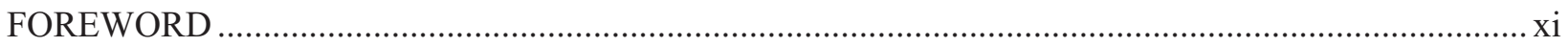

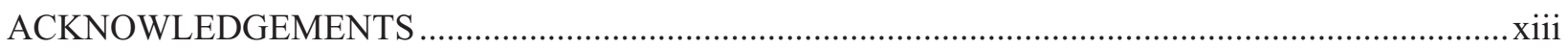

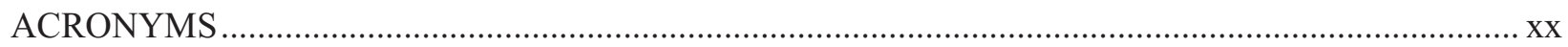

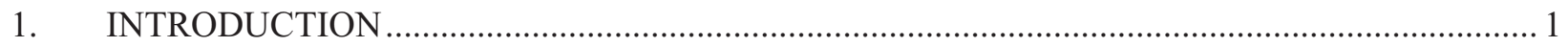

2. NDMAS DATA ANALYSIS AND WEB DELIVERY OVERVIEW ….................................... 3

2.1 Subjects of Analysis — Phenomena of Interest ............................................................... 3

2.2 Analysis Process for Various Groups of VHTR Researchers ............................................ 4

2.2.1 Data Analysis Capabilities via the NDMAS Web Portal ........................................... 4

2.2.2 Data Analysis and Web Delivery Capabilities for the NDMAS Team..................... 13

2.2.3 Data Analysis and Web Delivery Capabilities via Analysis Requests........................ 14

2.2.4 Data Analysis Capabilities via Downloads ................................................................ 14



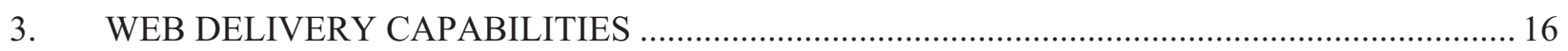

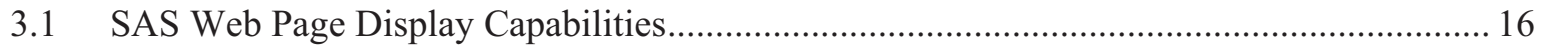

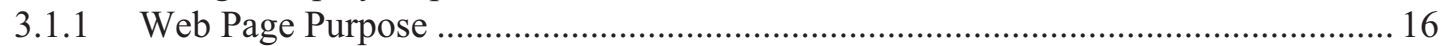

3.1.2 Three Types of Data and Two Types of Data Sources .............................................. 16

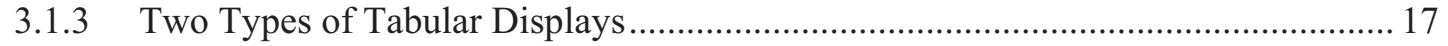

3.1.4 Methods for Grouping Data in SAS Reports ......................................................... 17

3.1.5 Graph Development and Layout Considerations ..................................................... 19

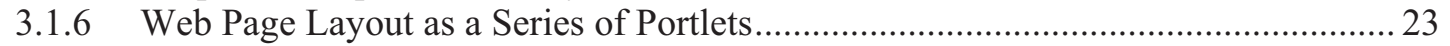

3.2 Application of Web Display Capabilities in NDMAS ..................................................... 29

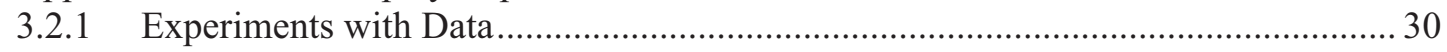

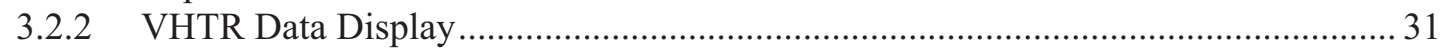

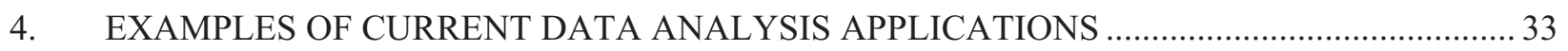

4.1 Suggested Neon Flow Rates for Capsules with No Working Thermocouples..................... 33

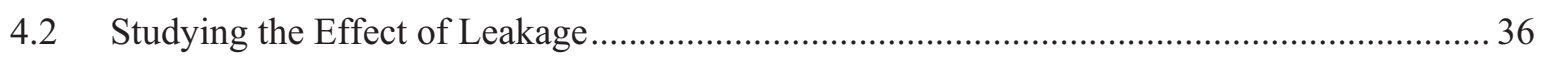



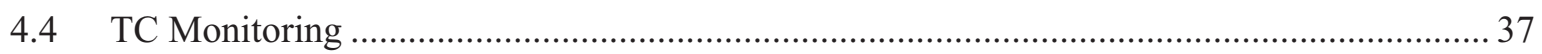

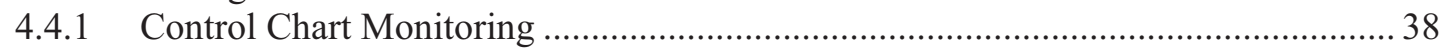

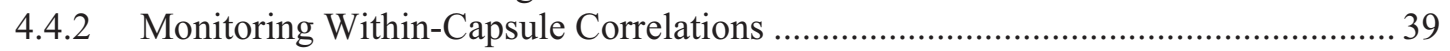

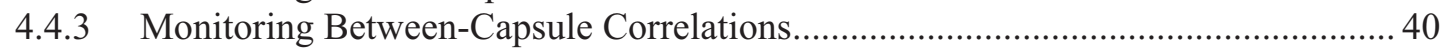

4.5 Use of the Data to Identify Possible Anomalies .................................................................... 40

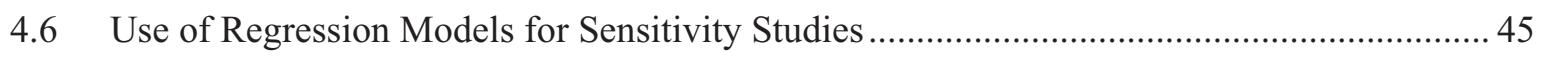

4.7 Potential Use of Regression Models for Experiment Control.............................................. 47 
5. ONGOING AND PROPOSED FUTURE DATA ANALYSES AND WEB DISPLAYS.

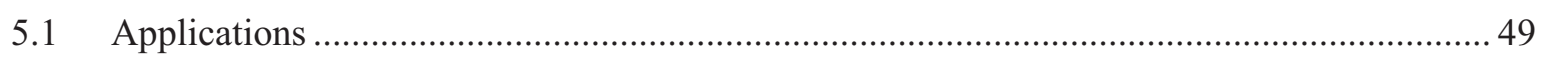



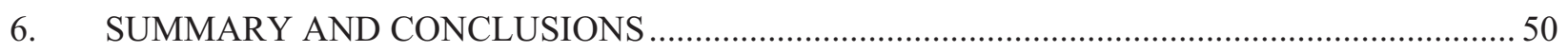

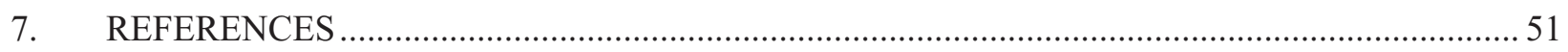

Appendix A VHTR Experiments and Associated Data Streams ....................................................... 53

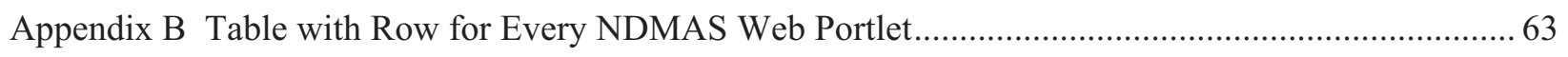

\section{FIGURES}

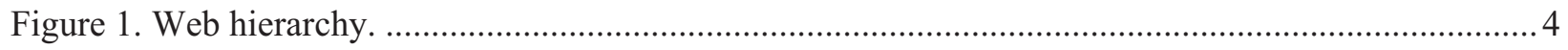

Figure 2. AGR-2 IRR web page showing three portlets. .................................................................. 5

Figure 3. Four major steps in NDMAS data processing. ..................................................................... 14

Figure 4. Ways to group data in reports (a, b: separate reports; c, group breaks; d, sections).................. 19

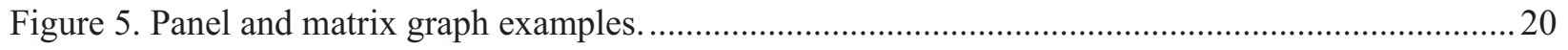



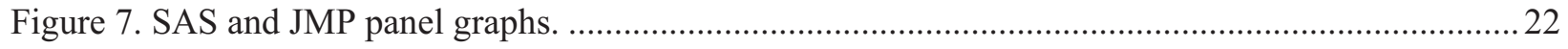



Figure 9. Menus after clicking "Month" headings in a report displaying a cube .....................................2

Figure 10. Cube plot Collapse/Drill Down options and table Expand/Drill Down icons........................227

Figure 11. AGR-2 Capsule 3 gas flow rates for July 14, 2010, expanded........................................... 28

Figure 12. Examples of use of HTML tags for special web displays. ....................................................22

Figure 13. AGR-2 capsule neon fractions (Capsules 1 and 4 are omitted due to Cooperative Research and Development Agreements [CRADA]) .......................................... 34

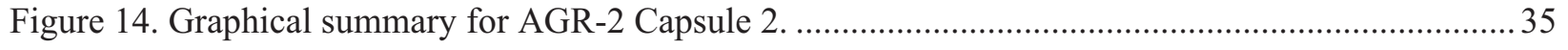

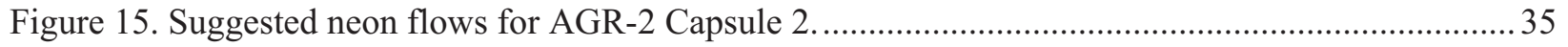

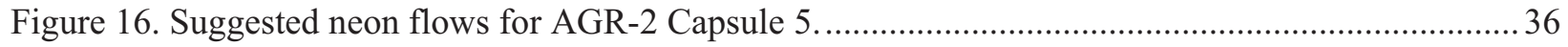

Figure 17. Integrated FAB, IRR, and PIE data for AGR-1 irradiated compacts. .................................. 37

Figure 18. Control chart for TC differences, with correlations and daily average TC readings

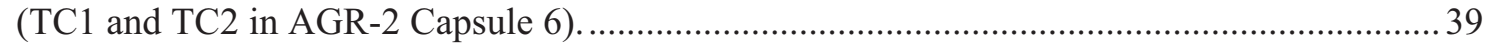

Figure 19. Monitoring between-capsule correlations for TCs in AGR-2 Capsule 6............................... 41

Figure 20. Measured and simulated AGR-1 TC temperatures................................................................42

Figure 21. Daily average data for AGR-1 Capsule 6 at full power.......................................................... 43

Figure 22. AGR-1 control chart for TC differences for TC1 and TC4 in Capsule 6............................... 44

Figure 23. Compendium of plots on possible drift of TC2 in Capsule 6 near end of AGR-1 irradiation. 
Figure 24. JMP prediction profiler for predicted fuel temperature in AGR-1 Capsule 6. 46

Figure 25. Regression model behind prediction profiler.

\section{TABLES}

Table S-1. Data analysis, display, and delivery capabilities in NDMAS web pages................................vii

Table 1. Advanced Graphite Creep experiment data analysis and display pages...................................... 5

Table 2. Advanced Gas Reactor Test 1 data analysis and display pages. ................................................ 7

Table 3. Advanced Gas Reactor Test 2 data analysis and display pages. ............................................... 10

Table 4. High temperature materials data analysis and display pages.................................................. 12

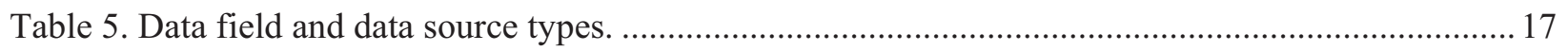

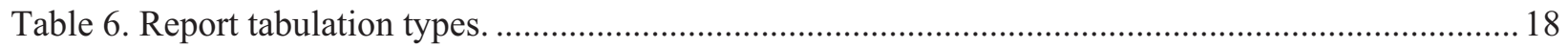

Table 7. Graph characteristics (other than graph form, font styles, colors, etc.). .................................... 23

Table 8. Common portlet types used in the NDMAS web pages........................................................... 24

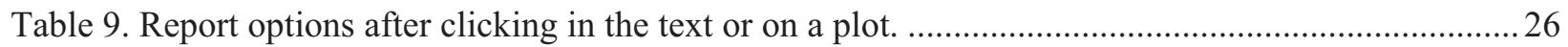

Table 10. Use of web display capabilities in the NDMAS web portal (excluding qualification

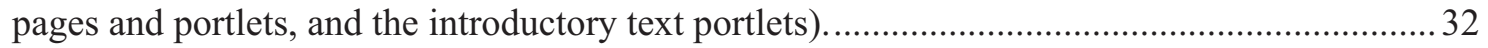

Table A-1. Fuel fabrication and compact data parameters. .................................................................. 56

Table A-2. Reactor irradiation data parameters and attributes for the AGR (fuel) experiments. ...............56

Table A-3. Fission product monitoring data parameters and attributes................................................5 56

Table A-4. ATR operating conditions data parameters and attributes...................................................56

Table A-5. NGNP neutronics and temperature analysis parameters and attributes.................................57

Table A-6. Fuel PIE data parameters and types (preliminary data) ......................................................5 57

Table A-7. Reactor irradiation monitoring parameters for the AGC (graphite) experiments.....................58

Table A-8. Parameters and classification for graphite specimens (characterization). ............................... 58

Table A-9. Planned HTM tests to characterize alloys for potential use in steam generators (SG)

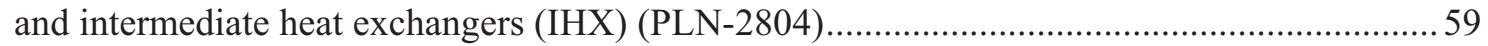

Table A-10. Planned HTM tests to characterize alloys for potential use in reactor pressure vessels

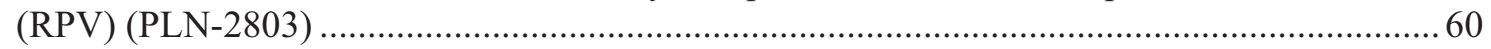

Table A-11. Parameters for HTM Characterization-Uniaxial Tension Tests (SG\&IHX Test A-1)..........61

Table A-12. Parameters for HTM Characterization-Cyclic Creep-Fatigue Tests

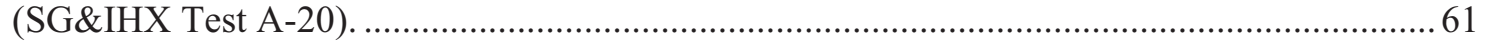

Table A-13. Parameters for typical HTM Characterization-Creep Tests............................................... 61

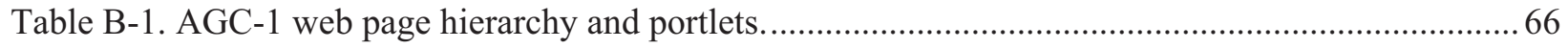

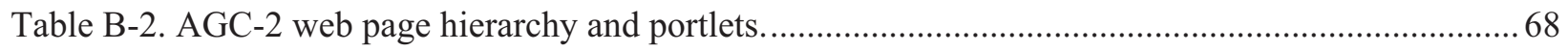

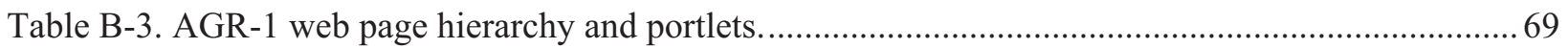


Table B-4. AGR-2 web page hierarchy and portlets.

Table B-5. HTM web hierarchy and portlets. 


\section{ACRONYMS}

AGC Advanced Graphite Creep

AGC-1 Advanced Graphite Creep Test 1

AGC-2 Advanced Graphite Creep Test 2

AGR Advanced Gas Reactor

AGR-1 Advanced Gas Reactor Test 1

AGR-2 Advanced Gas Reactor Test 2

ASME American Society of Mechanical Engineers

ATR Advanced Test Reactor

CDCS Capsule Distributed Control System

CHR characterization

CRADA cooperative research and development agreement

csv comma-separated value

CTE coefficient of thermal expansion

$\mathrm{CV} \quad$ coefficient of variation

DOE Department of Energy

EBI Enterprise Business Intelligence

EFPD effective full power days

EG enterprise guide

FAB fabrication

FPMS fission product monitoring system

Gen IV Generation IV

GG gross gamma

GTL graphics template language (SAS software)

HTE high temperature electrolysis

HTM high temperature materials

HTML hypertext markup language

IHX intermediate heat exchanger

INL Idaho National Laboratory

IRR irradiation

JMP JMP statistical discovery from SAS (software from SAS, Inc.)

LEU low-enriched uranium

MATLAB matrix laboratory software from The MathWorks, Inc.

$\mathrm{MPa} \quad$ megapascals 


$\begin{array}{ll}\text { MW } & \text { megawatts } \\ \text { NDMAS } & \text { NGNP Data Management and Analysis System } \\ \text { NGNP } & \text { Next Generation Nuclear Plant } \\ \text { OLAP } & \text { online analytical processing } \\ \text { PHY } & \text { physics } \\ \text { PIE } & \text { post-irradiation examination } \\ \text { Q } & \text { gas flow rate (more generally, a heat transfer quantity) } \\ \text { QA } & \text { quality assurance } \\ \text { QAPP } & \text { quality assurance program plan } \\ \text { R\&D } & \text { research and development } \\ \text { R/B } & \text { release-to-birth rate ratio } \\ \text { RDAS } & \text { Reactor Data Acquisition System } \\ \text { RPV } & \text { reactor pressure vessel } \\ \text { SAS } & \text { software from SAS Institute, Cary, NC } \\ \text { SAW } & \text { Submerged Arc Weld } \\ \text { SG } & \text { steam generator } \\ \text { SMT } & \text { Simplified Model Test } \\ \text { SQL } & \text { structured query language } \\ \text { TC } & \text { thermocouple } \\ \text { TDO } & \text { Technology Development Office } \\ \text { URL } & \text { Uniform Resource Locator } \\ \text { UTS } & \text { ultimate tensile strength } \\ \text { VHTR } & \text { very high temperature reactor } \\ & \end{array}$




\section{NGNP Data Management and Analysis System Analysis and Web Delivery Capabilities}

\section{INTRODUCTION}

Research and development (R\&D) activities are underway to support development of technology for the Generation IV (Gen IV) very high temperature reactor (VHTR). A particular focus of the research is on those activities required to design and license the first Next Generation Nuclear Plant (NGNP). The research is being conducted by an international team of research laboratories, universities, and private companies. The Technology Development Office (TDO) at Idaho National Laboratory (INL) oversees and coordinates this research. In FY 2008, TDO established the NGNP Data Management and Analysis System (NDMAS) to manage the large body of data being generated by the research. Through NDMAS, data generated from VHTR research can be stored in a controlled and secure electronic environment that ensures both its integrity and its availability for use by VHTR researchers. NDMAS provides a significant capability for allowing users to study the data and explore relationships among the attributes and responses being studied. This data analysis and display capability is the subject of this report.

NDMAS can be used to explore relationships in the VHTR research data at a number of levels. At the simplest level, researchers can view graphs of data and think about possible relationships that might exist between various physical quantities in the experiment.

Intuitive models that come from data visualization can be checked by empirical studies. One can estimate parameters, such as averages within groupings of data, and observe which groupings have better outcomes. Formal statistical tests can be performed to identify differences that are beyond the realm of normal variation. At a higher level, one can formulate mathematical relationships that might exist between various attributes or measured quantities, and fit these to the empirical data to see what relationships best represent the data.

More involved data analyses go beyond just empirical patterns and include known physical relationships between the quantities under study. Physical and empirical models can be combined to even better characterize relationships among the measured responses.

A final level of modeling involves simulation of dynamic conditions as they propagate in a complicated system over a period of time, such as thermal simulations of fuel temperatures. Such models are not part of the NDMAS modeling capabilities. NDMAS may support the development of such models, and certainly stores the outputs. Some of the experiments planned for the VHTR will produce data to calibrate and validate such models, and NDMAS analysis capabilities will facilitate the study of those data as well as other data generated by the VHTR R\&D program.

A major NDMAS capability that supports such analysis and display is the ability to store and display experimental and analytical results on the internet. NDMAS uses a SAS Enterprise Business Intelligence (EBI) web portal to make the experimental data and analytical results available to the VHTR research community.

Section 2 provides a further overview of the NDMAS analysis and web delivery capabilities, focused on system access by various groups of users. Section 3 presents details about the capabilities and how they are used for display on the web portal. Section 4 provides additional data analysis and display examples. Section 5 outlines ongoing applications and possible future studies that might provide further insights from the VHTR experiments. Section 6 provides conclusions and a summary. 
This Revision is an update of the report, NGNP Data Management and Analysis System Modeling Capabilities (INL/EXT-16327) originally published in September 2009 and previously updated in September 2010. All of the discussions focus on the status of the NDMAS as of September 2011. 


\section{NDMAS DATA ANALYSIS AND WEB DELIVERY OVERVIEW}

NDMAS data analysis is presented in this section from the standpoint of what the data models describe, how the analyses are performed by different groups of researchers, and how the results are or could be used to improve VHTR research.

\subsection{Subjects of Analysis-Phenomena of Interest}

Since the data analyses seek relationships between various experimental quantities, knowledge of the available data and associated processes is a prerequisite. The types of data currently stored in NDMAS are described briefly in this section and are itemized in Appendix A. A detailed description of the research data is beyond the scope of this document.

NDMAS has the capability of storing and documenting the qualification of all the data generated in the VHTR research. The data are processed as data packages for each data collection project or data stream. Currently, five projects have been identified:

- Fuel development and qualification

- Materials testing and qualification-graphite technology development

- Materials testing and qualification - high temperature materials

- Design methods and validation

- High Temperature Electrolysis (HTE) research and development.

Data have been input to NDMAS for the fuel development/qualification, graphite technology development, and high temperature materials projects.

A data stream is a set of parameters or measurements collected from one source that can be input into NDMAS together. A data stream may consist of a single set of data that is input just once, or it may be a set of data that is input repeatedly for different time frames (such as a time series) or for different experiments. The set of data submitted in each instance of input is called a data package. Appendix A describes NDMAS data streams and the associated inputs for the fuel and graphite projects, among others.

At the level of individual data points, each numeric or categorical value is associated with a component or experimental unit such as a fuel particle, fuel compact, capsule, or test train. Related records describe additional attributes for these entities. All data in NDMAS are stored in a Structured Query Language (SQL) database. This database has a table that shows the hierarchical relationship between the experimental entities.

NDMAS supports analyses of relationships between quantities in particular data packages. It also facilitates studies of data across data packages, such as from one reactor cycle to another. One can also combine data and study relationships among quantities from more than one data stream. Advanced Test Reactor (ATR) reactor operating conditions data, for example, are combined with VHTR irradiation experiment data for routine plotting and for analyses of controls on temperature. Data from different components, such as different fuel capsules, can also be visually compared using NDMAS. Particular modeling efforts can be geared to the objectives of each VHTR experiment, or to resolve particular questions posed by other VHTR researchers or stakeholders.

An important function that NDMAS provides for the modeling effort is to ensure that data used for the models are captured correctly, are accurate, and are suited for their intended use. These characteristics of the data are the focus of the data qualification section of NDMAS. After data are entered into the SQL database, they are checked to ensure that they are correctly captured (i.e., that they are identical to the raw data files supplied to NDMAS). As applicable, accuracy tests follow. An example of an accuracy test is the calculation of the coefficient of variation $(\mathrm{CV})$ for a set of data. If the $\mathrm{CV}$ is unusually large, the data 
set is flagged because possible outliers or transcription errors might exist. The overall suitability of the data is ensured by the fact that data marked as qualified were collected under the framework of ASME NQA-1-2008, 1a 2009, "Quality Assurance Requirements for Nuclear Facility Applications" or an equivalent QA program, as implemented through the VHTR Technology Development Office Quality Assurance Program Plan (INL 2011). NDMAS stores references to data reports that document the verification process that was applied for each set of qualified data.

\subsection{Analysis Process for Various Groups of VHTR Researchers}

NDMAS data analysis capabilities for particular researchers depend on the individual's level of access to the system. A number of user-specified options allow remote users who view NGNP data using the INL NDMAS web server to customize the displays they obtain for their own analysis needs. A broader range of modeling capabilities exists for members of the NDMAS Development Team, who create the web displays. A third analysis capability is for researchers to file requests for particular analyses to be performed by NDMAS team analysts. A fourth level of capability is completely unbounded; users can download data for their own analyses using whatever tools they prefer.

\subsubsection{Data Analysis Capabilities via the NDMAS Web Portal}

Several data analyses capabilities are part of the NDMAS web portal found at http://ndmas.inl.gov. (Note that one must contact the web services administrator to obtain a user ID and password in order to log in and access this web page). The web display capabilities include data visualization, data aggregation (summaries), and data expansion (drilling down to view more detail in the data). The capabilities vary according to the web page the user chooses to display. The modeling capabilities in the web pages showing current VHTR data are noted in subsections below.

The web content changes over time. The current discussion reflects the status of the web pages as of September 2011. The web pages are organized in an expandable hierarchy (Figure 1) with the top level containing links to web pages for the projects and major experiments that have supplied data thus far. For example, the Fuel Development and Qualification project currently has two major experiments with ATR irradiation data. Other toplevel entries describe other VHTR research projects.

Each page in the INL NDMAS web portal consists of one or more sections with teal-colored headers (for example, see Figure 2). The sections are called portlets. Tables 1 through 4 list all the portlets currently on the website (except those related to qualification and help). In web pages with lengthy portlets, two scroll bars appear on the right. The rightmost bar scrolls from one portlet to another, while the scroll bar just to the left of that one scrolls within a portlet.

To keep the navigation panel on the left side of the screen small, a set of abbreviations has been introduced (Figure 1) to describe the various pages. Tables 1-4 explain these acronyms and provide an overview of the pages that are presently available (other than qualification-related pages and helprelated pages). The analysis/web display capabilities of these pages are described further in Section 3.

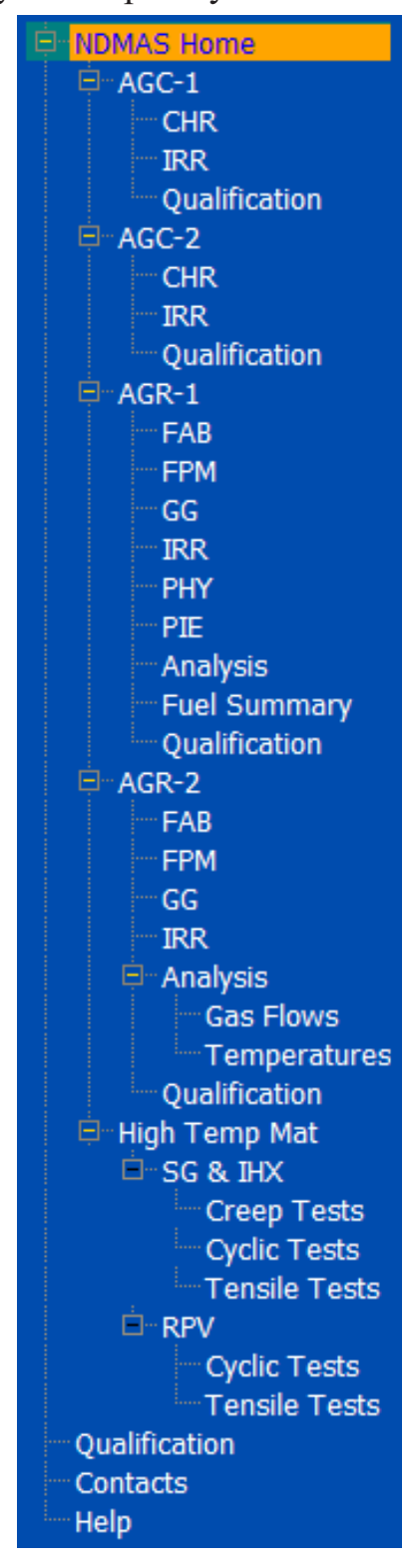

Figure 1. Web hierarchy. 


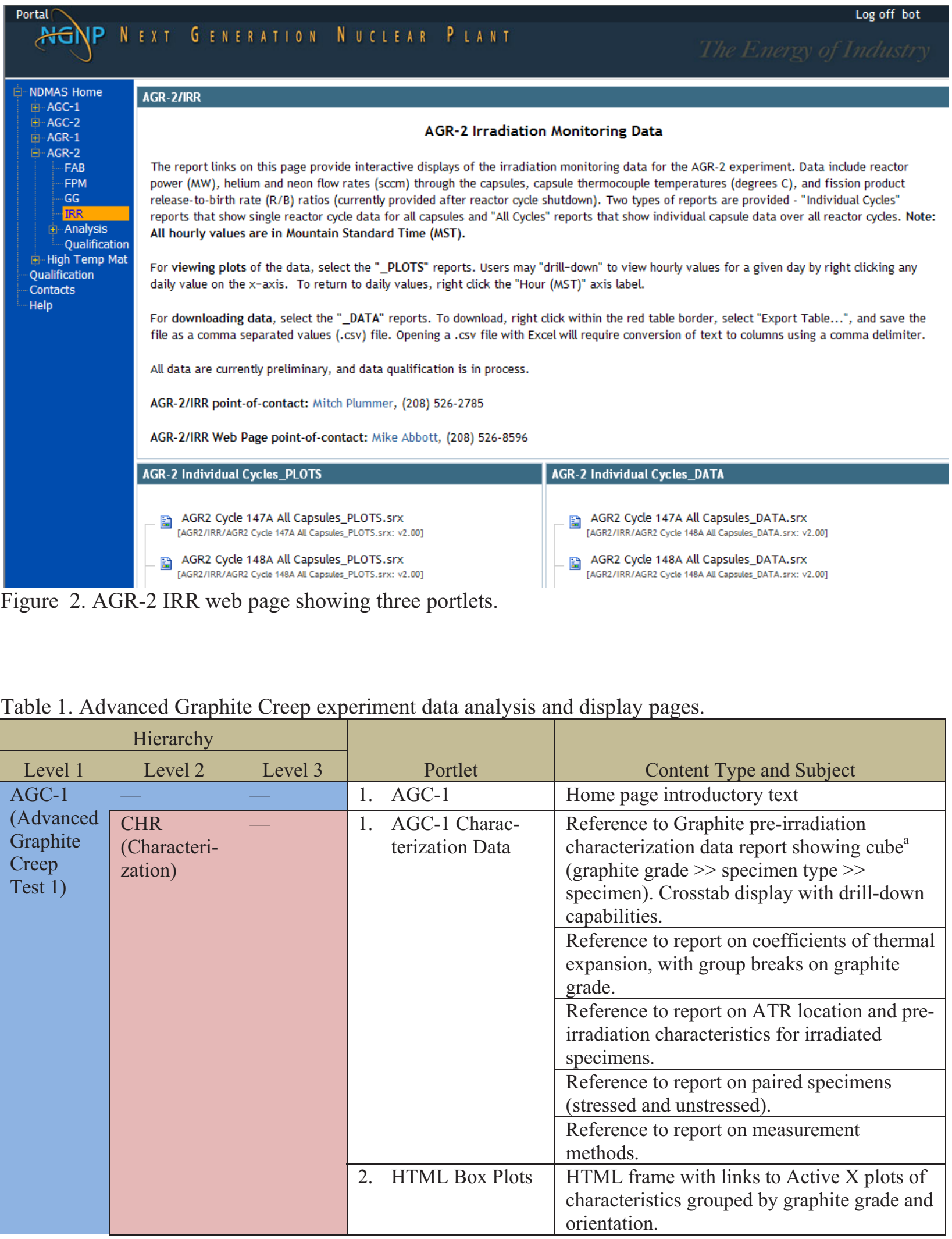


Table 1. (continued).

\begin{tabular}{|c|c|c|c|c|}
\hline \multicolumn{3}{|c|}{ Hierarchy } & \multirow[b]{2}{*}{ Portlet } & \multirow[b]{2}{*}{ Content Type and Subject } \\
\hline Level 1 & Level 2 & Level 3 & & \\
\hline \multirow{8}{*}{$\begin{array}{l}\text { AGC-1 } \\
\text { (Advanced } \\
\text { Graphite } \\
\text { Creep } \\
\text { Test 1) } \\
\text { (cont.) }\end{array}$} & \multirow{8}{*}{$\begin{array}{l}\text { IRR } \\
\text { (Irradia- } \\
\text { tion) }\end{array}$} & \multirow[t]{8}{*}{ - } & $\begin{array}{l}\text { 1. AGC-1 Irradiation } \\
\text { Monitoring }\end{array}$ & Introductory text \\
\hline & & & \multirow[t]{6}{*}{$\begin{array}{l}\text { 2. AGC-1 Irradiation } \\
\text { Monitoring Data }\end{array}$} & $\begin{array}{l}\text { Link to HTML graphs (static graphs } \\
\text { referenced in HTML files) showing } \\
\text { temperatures organized by distance from } \\
\text { thermocouple to the reactor centerline. }\end{array}$ \\
\hline & & & & $\begin{array}{l}\text { Link to HTML graphs showing ram pressure, } \\
\text { load cells, and stack positions. }\end{array}$ \\
\hline & & & & $\begin{array}{l}\text { Link to HTML graph showing AR/He gas } \\
\text { flow rates used for temperature control. }\end{array}$ \\
\hline & & & & $\begin{array}{l}\text { Link to HTML graphs of stack raising data } \\
\text { during outages. }\end{array}$ \\
\hline & & & & Reference to report with temperatures. \\
\hline & & & & $\begin{array}{l}\text { Reference to report with creep response data } \\
\text { (effective power, stack position, pneumatic } \\
\text { ram gas pressure, and compressive stress). }\end{array}$ \\
\hline & & & $\begin{array}{l}\text { 3. AGC-1 Graphical } \\
\text { Summary }\end{array}$ & $\begin{array}{l}\text { HTML panel graphs with effective power, } \\
\text { temperatures, stack positions and loads for } \\
\text { channels, and gas flows. }\end{array}$ \\
\hline \multirow{9}{*}{$\begin{array}{l}\text { AGC-2 } \\
\text { (Advanced } \\
\text { Graphite } \\
\text { Creep } \\
\text { Test 2) }\end{array}$} & - & - & $\begin{array}{l}\text { 1. AGC-2 Irradiation } \\
\text { Creep Experiment }\end{array}$ & Home page introductory text \\
\hline & $\begin{array}{l}\text { CHR } \\
\text { (Characteri- } \\
\text { zation) }\end{array}$ & - & $\begin{array}{l}\text { 1. AGC-2 Pre- } \\
\text { irradiation } \\
\text { Characterization }\end{array}$ & $\begin{array}{l}\text { Text stating that the data are not yet } \\
\text { available. }\end{array}$ \\
\hline & \multirow{7}{*}{$\begin{array}{l}\text { IRR } \\
\text { (Irradia- } \\
\text { tion) }\end{array}$} & \multirow[t]{7}{*}{-} & $\begin{array}{l}\text { 1. AGC-2 Irradiation } \\
\text { Monitoring }\end{array}$ & Introductory text \\
\hline & & & \multirow[t]{4}{*}{$\begin{array}{l}\text { 2. AGC-2 Irradiation } \\
\text { Monitoring Data }\end{array}$} & $\begin{array}{l}\text { Reference to report with data in time. Three } \\
\text { sections, based on displayed variables (stack } \\
\text { position, pneumatic ram gas pressure, and } \\
\text { compressive stress). Group breaks on ATR } \\
\text { cycle. }\end{array}$ \\
\hline & & & & $\begin{array}{l}\text { Reference to report with temperature time } \\
\text { series with group breaks on ATR cycle. }\end{array}$ \\
\hline & & & & $\begin{array}{l}\text { Same as above, except data describe gas } \\
\text { flows. }\end{array}$ \\
\hline & & & & $\begin{array}{l}\text { Link to HTML graphs of stack raising data } \\
\text { during outages. }\end{array}$ \\
\hline & & & $\begin{array}{l}\text { 3. Recent } \\
\text { Temperature } \\
\text { Profile }\end{array}$ & $\begin{array}{l}\text { HTML graph with temperature averages as a } \\
\text { function of distance of TC to ATR reactor } \\
\text { centerline. }\end{array}$ \\
\hline & & & $\begin{array}{l}\text { 4. AGC-2 Irradiation } \\
\text { Monitoring } \\
\text { Graphs }\end{array}$ & $\begin{array}{l}\text { HTML graphs of irradiation history } \\
\text { (effective power, temperatures, creep } \\
\text { response \& gas flows). }\end{array}$ \\
\hline & & & egating data in hierarch & $\begin{array}{l}\text { s. The hierarchy, listed in parentheses, shows the } \\
\text { ata structure is built to support displaying summary } \\
\text { hy. }\end{array}$ \\
\hline
\end{tabular}


Table 2. Advanced Gas Reactor Test 1 data analysis and display pages.

\begin{tabular}{|c|c|c|c|c|}
\hline \multicolumn{3}{|c|}{ Hierarchy } & \multirow[b]{2}{*}{ Portlet } & \multirow[b]{2}{*}{ Content Type and Subject } \\
\hline Level 1 & Level 2 & Level 3 & & \\
\hline \multirow{16}{*}{$\begin{array}{l}\text { AGR-1 } \\
\text { (Advanced } \\
\text { Gas } \\
\text { Reactor } \\
\text { Test 1) }\end{array}$} & \multirow[t]{5}{*}{-} & \multirow[t]{5}{*}{-} & $\begin{array}{l}\text { 1. NGNP AGR-1 } \\
\text { Data Summary }\end{array}$ & Home page introductory text \\
\hline & & & $\begin{array}{l}\text { 2. ATR Operating } \\
\text { Condition } \\
\text { Graphical } \\
\text { Summary } \\
\end{array}$ & $\begin{array}{l}\text { HTML panel graph showing ATR operating } \\
\text { conditions with ATR cycle background. }\end{array}$ \\
\hline & & & $\begin{array}{l}\text { 3. AGR-1 Graphical } \\
\text { Summary }\end{array}$ & $\begin{array}{l}\text { HTML panel graphs showing temperatures, gas } \\
\text { flow rates, etc. for each capsule. ATR cycle } \\
\text { background. }\end{array}$ \\
\hline & & & $\begin{array}{l}\text { 4. Fission Product } \\
\text { Release by } \\
\text { Capsule and } \\
\text { Cycle }\end{array}$ & $\begin{array}{l}\text { HTML panel graphs of release and R/B } \\
\text { (release to birth) ratios. }\end{array}$ \\
\hline & & & $\begin{array}{l}\text { 5. AGR-1 Cycle } \\
\text { Statistics } \\
\text { Summary }\end{array}$ & $\begin{array}{l}\text { HTML graphs showing cycle averages for } \\
\text { effective power, temperatures, gas flows, and } \\
\text { R/B ratios. }\end{array}$ \\
\hline & \multirow{4}{*}{$\begin{array}{l}\text { FAB } \\
\text { (Fabri- } \\
\text { cation) }\end{array}$} & \multirow[t]{4}{*}{ - } & $\begin{array}{l}\text { 1. AGR-1 Fuel } \\
\text { Fabrication Data }\end{array}$ & Introductory text \\
\hline & & & \multirow[t]{3}{*}{$\begin{array}{l}\text { 2. Fuel Fabrication } \\
\text { Data Reports }\end{array}$} & $\begin{array}{l}\text { Reference to static report with } 11 \text { tables } \\
\text { ("Report object") describing fuel kernels, } \\
\text { layers, particles, compacts, compact } \\
\text { dimensions, etc. }\end{array}$ \\
\hline & & & & $\begin{array}{l}\text { Reference to static report with } 11 \text { tables } \\
\text { grouped by "Type" ("Report object"), with } \\
\text { similar content to the previous report except } \\
\text { that means, sample sizes and standard } \\
\text { deviations are given. }\end{array}$ \\
\hline & & & & $\begin{array}{l}\text { Reference to static report with } 5 \text { tables } \\
\text { ("Report object") about the measurement } \\
\text { methods. }\end{array}$ \\
\hline & \multirow[t]{7}{*}{$\begin{array}{l}\text { FPM } \\
\text { (Fission } \\
\text { product } \\
\text { monitoring) }\end{array}$} & \multirow[t]{7}{*}{ - } & $\begin{array}{l}\text { 1. AGR-1 Fission } \\
\text { Product Moni- } \\
\text { toring System } \\
\text { (FPMS) Data }\end{array}$ & Introductory text \\
\hline & & & $\begin{array}{l}\text { 2. FPMS Release } \\
\text { Data }\end{array}$ & $\begin{array}{l}\text { Reference to reports of isotope release history } \\
\text { for the capsules for each ATR cycle. }\end{array}$ \\
\hline & & & 3. FPMS R/B Data & $\begin{array}{l}\text { Reference to reports of R/B history for the } \\
\text { capsules for each ATR cycle. }\end{array}$ \\
\hline & & & \multirow[t]{4}{*}{$\begin{array}{l}\text { 4. Release Rate } \\
\text { Plots and } \\
\text { Distributions }\end{array}$} & $\begin{array}{l}\text { Link to HTML panel graph of release rates, } \\
\text { with release rate history panels for each } \\
\text { capsule. }\end{array}$ \\
\hline & & & & $\begin{array}{l}\text { Link to HTML graph showing release rate box } \\
\text { plots plotted against the ATR cycle numbers, } \\
\text { with a panel for each capsule. }\end{array}$ \\
\hline & & & & $\begin{array}{l}\text { Link to HTML graph with box plots of Kr85m } \\
\text { data by capsule and cycle plotted in one panel. }\end{array}$ \\
\hline & & & & $\begin{array}{l}\text { Link to JMP histograms, quantiles, and } \\
\text { moments by ATR cycle for log release rates } \\
\text { ( } 3 \text { isotopes). }\end{array}$ \\
\hline
\end{tabular}


Table 2. (continued).

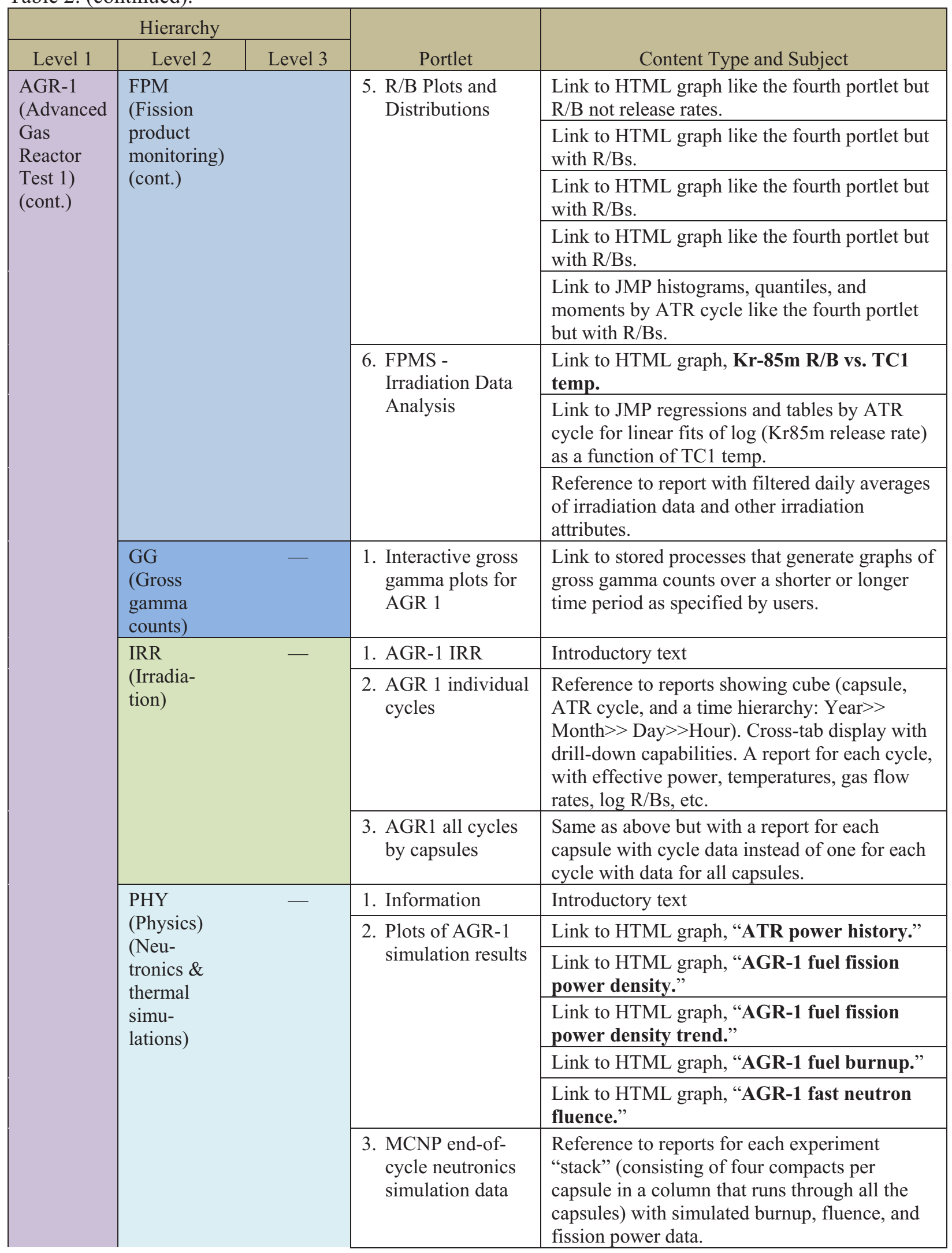


Table 2. (continued).

\begin{tabular}{|c|c|c|c|c|}
\hline \multicolumn{3}{|c|}{ Hierarchy } & \multirow[b]{2}{*}{ Portlet } & \multirow[b]{2}{*}{ Content Type and Subject } \\
\hline Level 1 & Level 2 & Level 3 & & \\
\hline \multirow{14}{*}{$\begin{array}{l}\text { AGR-1 } \\
\text { (Advanced } \\
\text { Gas } \\
\text { Reactor } \\
\text { Test 1) } \\
\text { (cont.) }\end{array}$} & \multirow{2}{*}{\multicolumn{2}{|c|}{$\begin{array}{l}\text { PHY } \\
\text { (Physics) } \\
\text { (Neutronics } \\
\& \text { thermal } \\
\text { simulations) } \\
\text { (cont.) }\end{array}$}} & $\begin{array}{l}\text { 4. JMOCUP daily } \\
\text { neutronics } \\
\text { simulation data }\end{array}$ & $\begin{array}{l}\text { Reference to reports with physics parameters } \\
\text { for the stacks and other components and } \\
\text { estimates daily capsule fission power densities. }\end{array}$ \\
\hline & & & $\begin{array}{l}\text { 5. ABAQUS daily } \\
\text { thermal } \\
\text { simulation }\end{array}$ & $\begin{array}{l}\text { Reference to reports with simulated daily } \\
\text { average fuel and TC temperatures. }\end{array}$ \\
\hline & \multirow{3}{*}{$\begin{array}{l}\text { PIE } \\
\text { (Post- } \\
\text { irradiation } \\
\text { examination) }\end{array}$} & \multirow{3}{*}{-} & 1. AGR-1/PIE & Introductory text \\
\hline & & & $\begin{array}{l}\text { 2. Metrology data } \\
\text { mart }\end{array}$ & $\begin{array}{l}\text { Reference to reports on sizes of compacts after } \\
\text { irradiation. }\end{array}$ \\
\hline & & & $\begin{array}{l}\text { 3. Metrology native } \\
\text { Excel files }\end{array}$ & Links to Excel files with source data. \\
\hline & \multirow{5}{*}{$\begin{array}{l}\text { Analysis } \\
\text { (TC } \\
\text { reliability) }\end{array}$} & \multirow[t]{5}{*}{-} & $\begin{array}{l}\text { 1. AGR-1 analysis } \\
\text { introduction }\end{array}$ & Introductory text \\
\hline & & & $\begin{array}{l}\text { 2. AGR-1 pair TC } \\
\text { temperatures and } \\
\text { within-capsule } \\
\text { correlation }\end{array}$ & $\begin{array}{l}\text { HTML graphs comparing pairs of TCs in the } \\
\text { same capsule to see if their readings are } \\
\text { similar. Includes control charts for the } \\
\text { differences. }\end{array}$ \\
\hline & & & $\begin{array}{l}\text { 3. AGR-1 junction } \\
\text { detection by } \\
\text { correlation } \\
\text { analysis }\end{array}$ & $\begin{array}{l}\text { HTML graphs showing, for each TC, the } \\
\text { capsule with the TC whose daily readings are } \\
\text { most highly correlated with the subject TC's } \\
\text { daily readings. The correlated TC readings are } \\
\text { expected to be in the same capsule. }\end{array}$ \\
\hline & & & $\begin{array}{l}\text { 4. AGR-1 } \\
\text { correlation cycle } \\
\text { statistics }\end{array}$ & $\begin{array}{l}\text { HTML graphs with box plots of between- } \\
\text { capsule daily TC correlations and within- } \\
\text { capsule correlations. The within-capsule ones } \\
\text { are expected to be closer to } 1 \text { and have less } \\
\text { variation than the between-capsule box plots. }\end{array}$ \\
\hline & & & $\begin{array}{l}\text { 5. Daily averaged } \\
\text { TC readings and } \\
\text { cycle statistics }\end{array}$ & $\begin{array}{l}\text { HTML graphs with daily averages for each } \\
\text { ATR cycle and shading showing the estimated } \\
\text { standard deviation of the averages. }\end{array}$ \\
\hline & \multirow[t]{4}{*}{$\begin{array}{l}\text { Fuel } \\
\text { Summary }\end{array}$} & \multirow[t]{4}{*}{-} & $\begin{array}{l}\text { 1. Fuel compact } \\
\text { summary }\end{array}$ & Introductory text \\
\hline & & & 2. Data table & $\begin{array}{l}\text { Reference to report with merged data from } \\
\text { fabrication, fission product monitoring, physics } \\
\text { simulations, and post-irradiation examination. }\end{array}$ \\
\hline & & & $\begin{array}{l}\text { 3. Fuel compact } \\
\text { irradiation data }\end{array}$ & $\begin{array}{l}\text { HTML graph showing average simulated } \\
\text { compact attributes such as instantaneous, } \\
\text { time-average peak and time-average volume } \\
\text { average temperatures. Each measure is in a } \\
\text { panel with plots for each of three fuel stacks. } \\
\text { Data are arranged left to right from the top to } \\
\text { the bottom of the test train. }\end{array}$ \\
\hline & & & $\begin{array}{l}\text { 4. Fuel compact } \\
\text { dimensions }\end{array}$ & $\begin{array}{l}\text { HTML graphs showing (1) compact shrinkage } \\
{[100 * \text { (PIE size - FAB size)/FAB size] with a }} \\
\text { panel for diameters and one for lengths; } \\
\text { (2) diameters, and (3) lengths. Data are } \\
\text { arranged, as above, by compact position. }\end{array}$ \\
\hline
\end{tabular}


Table 2. (continued).

\begin{tabular}{|c|c|c|c|c|}
\hline \multicolumn{3}{|c|}{ Hierarchy } & \multirow[b]{2}{*}{ Portlet } & \multirow[b]{2}{*}{ Content Type and Subject } \\
\hline Level 1 & Level 2 & Level 3 & & \\
\hline \multirow[t]{2}{*}{$\begin{array}{l}\text { AGR-1 } \\
\text { (Advanced } \\
\text { Gas } \\
\text { Reactor } \\
\text { Test 1) } \\
\text { (cont.) }\end{array}$} & \multirow{2}{*}{\multicolumn{2}{|c|}{$\begin{array}{l}\text { Fuel } \\
\text { Summary } \\
\text { (cont.) }\end{array}$}} & $\begin{array}{l}\text { 5. Fuel compact } \\
\text { fabrication data }\end{array}$ & $\begin{array}{l}\text { HTML graph with individual compact mass } \\
\text { and molding pressures in successive panels. } \\
\text { Variant-average OPyC anistropy, U loading, } \\
\text { and masses of various impurities in the IPyC, } \\
\text { OPyC, SiC and Buffer layers are in the bottom } \\
\text { panels. }\end{array}$ \\
\hline & & & $\begin{array}{l}\text { 6. Fuel particle } \\
\text { fabrication data }\end{array}$ & $\begin{array}{l}\text { HTML graph with panels with variant-level } \\
\text { average particle aspect ratios; thicknesses of } \\
\text { the IPyC, OPyC, and SiC layers; sink-float } \\
\text { based density measures, and other fabrication } \\
\text { data. The variant data are plotted as horizontal } \\
\text { lines on the same axes as the compact data } \\
\text { (each capsule's compacts are from the same } \\
\text { fuel variant). }\end{array}$ \\
\hline
\end{tabular}

Table 3. Advanced Gas Reactor Test 2 data analysis and display pages.

\begin{tabular}{|c|c|c|c|c|}
\hline \multicolumn{3}{|c|}{ Hierarchy } & \multirow[b]{2}{*}{ Portlet } & \multirow[b]{2}{*}{ Content Type and Subject } \\
\hline Level 1 & Level 2 & Level 3 & & \\
\hline \multirow{10}{*}{$\begin{array}{l}\text { AGR-2 } \\
\text { (Advanced } \\
\text { Gas } \\
\text { Reactor } \\
\text { Test 2) }\end{array}$} & \multirow[t]{5}{*}{-} & \multirow[t]{5}{*}{-} & $\begin{array}{l}\text { 1. AGR-2 data } \\
\text { summary }\end{array}$ & Home page introductory text \\
\hline & & & $\begin{array}{l}\text { 2. ATR operating } \\
\text { parameters and Ne } \\
\text { fractions - daily } \\
\text { averages }\end{array}$ & Reference to report with averages. \\
\hline & & & $\begin{array}{l}\text { 3. ATR operating } \\
\text { conditions } \\
\text { graphical } \\
\text { summary }\end{array}$ & $\begin{array}{l}\text { HTML graph showing ATR operating } \\
\text { conditions with ATR cycle background. }\end{array}$ \\
\hline & & & $\begin{array}{l}\text { 4. AGR-2 graphical } \\
\text { summary }\end{array}$ & $\begin{array}{l}\text { HTML panel graphs showing temperatures, } \\
\text { gas flow rates, etc. for each capsule. ATR } \\
\text { cycle background. }\end{array}$ \\
\hline & & & $\begin{array}{l}\text { 5. AGR-2 graphical } \\
\text { summary for } \\
\text { current cycle }\end{array}$ & $\begin{array}{l}\text { HTML panel graphs showing temperatures, } \\
\text { gas flow rates, etc. for each capsule for one } \\
\text { cycle (so the abscissa is expanded compared } \\
\text { with Portlet 4). }\end{array}$ \\
\hline & \multirow{5}{*}{$\begin{array}{l}\text { FAB } \\
\text { (Fabri- } \\
\text { cation) }\end{array}$} & & 1. Introduction & Introductory text \\
\hline & & & 2. Anisotropy & $\begin{array}{l}\text { Displayed report with two "cube" data tables. } \\
\text { Cross-tab display with averaged data. Drill } \\
\text { down to observe individual measurements on } \\
\text { inner and outer pyrolitic carbon layers. }\end{array}$ \\
\hline & & & 3. Aspect ratio & $\begin{array}{l}\text { Displayed report with graph showing two } \\
\text { histograms. The plotted data are } \\
\text { downloadable. }\end{array}$ \\
\hline & & & $\begin{array}{l}\text { 4. Particle } \\
\text { contaminants }\end{array}$ & $\begin{array}{l}\text { Displayed report with defect fractions for } \\
\text { layers and U contamination fractions for } \mathrm{U} \\
\text { sources. }\end{array}$ \\
\hline & & & $\begin{array}{l}\text { 5. Compact } \\
\text { impurities }\end{array}$ & $\begin{array}{l}\text { Displayed report with cross-tab table with } \\
\text { means for U loadings and impurity masses for } \\
\text { compacts. }\end{array}$ \\
\hline
\end{tabular}


Table 3. (continued).

\begin{tabular}{|c|c|c|c|c|}
\hline \multicolumn{3}{|c|}{ Hierarchy } & \multirow[b]{2}{*}{ Portlet } & \multirow[b]{2}{*}{ Content Type and Subject } \\
\hline Level 1 & Level 2 & Level 3 & & \\
\hline \multirow{18}{*}{$\begin{array}{l}\text { AGR-2 } \\
\text { (Advanced } \\
\text { Gas } \\
\text { Reactor } \\
\text { Test 2) } \\
\text { (cont.) }\end{array}$} & \multirow{3}{*}{\multicolumn{2}{|c|}{$\begin{array}{l}\text { FAB } \\
\text { (Fabri- } \\
\text { cation) } \\
\text { (cont.) }\end{array}$}} & 6. Matrix impurities & Displayed report with impurity fractions, etc. \\
\hline & & & 7. Summary data & $\begin{array}{l}\text { Displayed report with cross-tab table showing } \\
\text { sizes and other parameters. }\end{array}$ \\
\hline & & & 8. Compact data & $\begin{array}{l}\text { Reference to report w/8 sections of fabrication } \\
\text { data (see Appendix B for more details). }\end{array}$ \\
\hline & \multirow{5}{*}{$\begin{array}{l}\text { FPM } \\
\text { (Fission } \\
\text { product } \\
\text { moni- } \\
\text { toring) }\end{array}$} & \multirow[t]{5}{*}{ - } & $\begin{array}{l}\text { 1. AGR2- FPMS } \\
\text { release and R/B } \\
\text { data page } \\
\text { summary }\end{array}$ & Introductory text \\
\hline & & & $\begin{array}{l}\text { 2. FPMS processing } \\
\text { data }\end{array}$ & $\begin{array}{l}\text { Reference to report with detailed capsule } \\
\text { outlet gas flow rate data. }\end{array}$ \\
\hline & & & $\begin{array}{l}\text { 3. FPMS data mart - } \\
\text { release rates }\end{array}$ & $\begin{array}{l}\text { Reference to reports, with release rates for } \\
\text { each ATR cycle. Also has a link to a HTML } \\
\text { graph summarizing the release rate history } \\
\text { with panels for the compacts. }\end{array}$ \\
\hline & & & $\begin{array}{l}\text { 4. FPMS data mart - } \\
\mathrm{R} / \mathrm{B} \text { ratios }\end{array}$ & $\begin{array}{l}\text { Reference to reports and a link to a HTML } \\
\text { graph, like the third portlet but with R/B data } \\
\text { rather than release data. }\end{array}$ \\
\hline & & & $\begin{array}{l}\text { 5. R/B plot - all } \\
\text { cycles }\end{array}$ & $\begin{array}{l}\text { HTML graph with a panel for each capsule, } \\
\text { showing the R/B data history with ATR cycle } \\
\text { shading in the background. }\end{array}$ \\
\hline & \multirow{5}{*}{$\begin{array}{l}\text { GG } \\
\text { (Gross } \\
\text { gamma } \\
\text { counts) }\end{array}$} & \multirow[t]{5}{*}{-} & $\begin{array}{l}\text { 1. AGR-2 gross } \\
\text { gamma plots }\end{array}$ & Introductory text \\
\hline & & & $\begin{array}{l}\text { 2. Gross gamma for } \\
\text { the last } 24 \text { hours }\end{array}$ & $\begin{array}{l}\text { Links to HTML graphs showing the most } \\
\text { recent day's counts. There is a link for each } \\
\text { detector. }\end{array}$ \\
\hline & & & $\begin{array}{l}\text { 3. Gross gamma for } \\
\text { the last } 7 \text { days }\end{array}$ & $\begin{array}{l}\text { Links to HTML graphs showing the most } \\
\text { recent } 7 \text { days' counts. A link for each detector. }\end{array}$ \\
\hline & & & $\begin{array}{l}\text { 4. Daily statistics for } \\
\text { gross gamma by } \\
\text { capsule }\end{array}$ & $\begin{array}{l}\text { HTML graph showing daily average and } \\
\text { maximum counts in panels for each detector } \\
\text { with background ATR cycle shading. }\end{array}$ \\
\hline & & & $\begin{array}{l}\text { 5. AGR-2 interactive } \\
\text { gross gamma plots }\end{array}$ & $\begin{array}{l}\text { Link to stored processes that generate graphs } \\
\text { as specified by users. }\end{array}$ \\
\hline & \multirow{5}{*}{$\begin{array}{l}\text { IRR } \\
\text { (Irradia- } \\
\text { tion) }\end{array}$} & \multirow{5}{*}{-} & 1. AGR-2/IRR & Introductory text \\
\hline & & & $\begin{array}{l}\text { 2. AGR-2 individual } \\
\text { cycles_PLOTS }\end{array}$ & $\begin{array}{l}\text { Reference to reports showing cube (capsule, } \\
\text { ATR cycle, and a time hierarchy: Year }>> \\
\text { Month }>>\text { Day }>>\text { Hour). Cross-tab display } \\
\text { with drill-down capabilities. One report for } \\
\text { each cycle, with cycle statistics such as } \\
\text { effective power, gas flows, TC temperatures, } \\
\text { and } \log \text { R/B ratios. }\end{array}$ \\
\hline & & & $\begin{array}{l}\text { 3. AGR-2 individual } \\
\text { cycles_DATA }\end{array}$ & $\begin{array}{l}\text { References to reports as above but without the } \\
\text { plots. }\end{array}$ \\
\hline & & & $\begin{array}{l}\text { 4. AGR-2 all cycles } \\
\text { by capsule_ } \\
\text { PLOTS }\end{array}$ & $\begin{array}{l}\text { References to reports like second portlet } \\
\text { above but by capsule instead of by ATR cycle. }\end{array}$ \\
\hline & & & $\begin{array}{l}\text { 5. AGR-2 all cycles } \\
\text { by capsule_DATA }\end{array}$ & Same as above but without the plots \\
\hline
\end{tabular}


Table 3. (continued).

\begin{tabular}{|c|c|c|c|c|}
\hline \multicolumn{3}{|c|}{ Hierarchy } & \multirow[b]{2}{*}{ Portlet } & \multirow[b]{2}{*}{ Content Type and Subject } \\
\hline Level 1 & Level 2 & Level 3 & & \\
\hline \multirow{13}{*}{$\begin{array}{l}\text { AGR-2 } \\
\text { (Advanced } \\
\text { Gas } \\
\text { Reactor } \\
\text { Test 2) } \\
\text { (cont.) }\end{array}$} & \multirow[t]{13}{*}{ Analysis } & - & $\begin{array}{l}\text { 1. AGR-2 analysis } \\
\text { home }\end{array}$ & Introductory text \\
\hline & & \multirow[t]{6}{*}{ Gas Flows } & $\begin{array}{l}\text { 1. AGR-2 gas flows } \\
\text { — introduction }\end{array}$ & Introductory text \\
\hline & & & $\begin{array}{l}\text { 2. Ne flow for } \\
\text { capsules with no } \\
\text { operating TCs }\end{array}$ & $\begin{array}{l}\text { HTML graphs showing Ne flows for Capsules } \\
2 \text { and } 5 \text {, including suggested flows based on } \\
\text { regression models. }\end{array}$ \\
\hline & & & 3. Neon fraction & $\begin{array}{l}\text { HTML panel graph with } \mathrm{Ne} \text { fractions for each } \\
\text { capsule. }\end{array}$ \\
\hline & & & 4. Gas flows & HTML graph with gas flows for each capsule. \\
\hline & & & 5. TC temperatures & $\begin{array}{l}\text { HTML graph with TC readings for each } \\
\text { capsule. }\end{array}$ \\
\hline & & & $\begin{array}{l}\text { 6. Gas flows data - } \\
\text { daily averages }\end{array}$ & $\begin{array}{l}\text { Reference to report with downloadable gas } \\
\text { flow data. }\end{array}$ \\
\hline & & \multirow[t]{6}{*}{$\begin{array}{l}\text { Tempera- } \\
\text { tures }\end{array}$} & $\begin{array}{l}\text { 1. Temperature data } \\
\text { analysis }\end{array}$ & Introductory text \\
\hline & & & 2. TC temperatures & $\begin{array}{l}\text { HTML graph with TC readings for each } \\
\text { capsule. }\end{array}$ \\
\hline & & & $\begin{array}{l}\text { 3. TC drift detection } \\
\text { from within- } \\
\text { capsule } \\
\text { comparisons }\end{array}$ & $\begin{array}{l}\text { HTML graphs with control charts, like the } \\
\text { second portlet in the AGR-1/Analysis web } \\
\text { page. }\end{array}$ \\
\hline & & & $\begin{array}{l}\text { 4. TC junction } \\
\text { detection using } \\
\text { daily correlations }\end{array}$ & $\begin{array}{l}\text { HTML graphs like the third portlet in the } \\
\text { AGR-1/Analysis web page. }\end{array}$ \\
\hline & & & $\begin{array}{l}\text { 5. TC junction } \\
\text { detection using } \\
\text { correlations } \\
\text { between control } \\
\text { TCs }\end{array}$ & $\begin{array}{l}\text { HTML graphs like the fourth portlet in the } \\
\text { AGR-1/Analysis web page. }\end{array}$ \\
\hline & & & $\begin{array}{l}\text { 6. Daily average TC } \\
\text { temperatures with } \\
\text { cycle statistics }\end{array}$ & $\begin{array}{l}\text { HTML graphs similar to those in the fifth } \\
\text { portlet in the AGR-1/Analysis web page. }\end{array}$ \\
\hline
\end{tabular}

Table 4. High temperature materials data analysis and display pages.

\begin{tabular}{|c|c|c|c|c|}
\hline \multicolumn{3}{|c|}{ Hierarchy } & \multirow[b]{2}{*}{ Portlet } & \multirow[b]{2}{*}{ Content Type and Subject } \\
\hline Level 1 & Level 2 & Level 3 & & \\
\hline \multirow{4}{*}{$\begin{array}{l}\text { HTM } \\
\text { (High } \\
\text { tem- } \\
\text { perature } \\
\text { materials) }\end{array}$} & - & - & $\begin{array}{l}\text { 1. High temperature } \\
\text { materials testing }\end{array}$ & Home page introductory text \\
\hline & \multirow{3}{*}{$\begin{array}{l}\text { SG \& IHX } \\
\text { (Steam } \\
\text { generator } \\
\text { \& interme- } \\
\text { diate heat } \\
\text { exchanger) }\end{array}$} & - & $\begin{array}{l}\text { 1. Steam generator } \\
\text { and intermediate } \\
\text { heat exchanger }\end{array}$ & Introductory text \\
\hline & & \multirow{2}{*}{$\begin{array}{l}\text { Creep } \\
\text { tests }\end{array}$} & 1. Creep testing & Introductory text \\
\hline & & & $\begin{array}{l}\text { 2. Creep tests for } \\
\text { Alloy } 617\end{array}$ & $\begin{array}{l}\text { HTML tabs with links to embedded graphs, } \\
\text { data tables, and stored processes that support } \\
\text { user-specified graphics and data downloads. }\end{array}$ \\
\hline
\end{tabular}


Table 4. (continued).

\begin{tabular}{|c|c|c|c|c|}
\hline \multicolumn{3}{|c|}{ Hierarchy } & \multirow[b]{2}{*}{ Portlet } & \multirow[b]{2}{*}{ Content Type and Subject } \\
\hline Level 1 & Level 2 & Level 3 & & \\
\hline \multirow{10}{*}{$\begin{array}{l}\text { HTM } \\
\text { (High } \\
\text { tem- } \\
\text { perature } \\
\text { materials) } \\
\text { (cont.) }\end{array}$} & \multirow{5}{*}{$\begin{array}{l}\text { SG \& IHX } \\
\text { (Steam } \\
\text { generator } \\
\text { \& interme- } \\
\text { diate heat } \\
\text { exchanger) } \\
\text { (cont.) }\end{array}$} & \multirow{3}{*}{$\begin{array}{l}\text { Cyclic } \\
\text { tests }\end{array}$} & 1. Cyclic testing & Introductory text \\
\hline & & & $\begin{array}{l}\text { 2. Baseline creep- } \\
\text { fatigue tests on } \\
\text { Alloy } 617\end{array}$ & $\begin{array}{l}\text { HTML tabs with links to embedded graphs, } \\
\text { data tables, and stored processes that support } \\
\text { data downloads. }\end{array}$ \\
\hline & & & $\begin{array}{l}\text { 3. Creep-fatigue } \\
\text { tests on welded } \\
\text { Alloy } 617 \\
\end{array}$ & Same as above \\
\hline & & \multirow{2}{*}{$\begin{array}{l}\text { Tensile } \\
\text { tests }\end{array}$} & 1. Tensile testing & Introductory text \\
\hline & & & 2. Strength tests & $\begin{array}{l}\text { HTML tabs with links to embedded graphs, } \\
\text { data tables, and stored processes that support } \\
\text { data downloads. }\end{array}$ \\
\hline & \multirow{5}{*}{$\begin{array}{l}\text { RPV } \\
\text { (Reactor } \\
\text { pressure } \\
\text { vessel) }\end{array}$} & - & $\begin{array}{l}\text { 1. Reactor pressure } \\
\text { vessel }\end{array}$ & Introductory text \\
\hline & & \multirow[t]{2}{*}{$\begin{array}{l}\text { Cyclic } \\
\text { tests }\end{array}$} & $\begin{array}{l}\text { 1. Introduction to } \\
\text { cyclic testing }\end{array}$ & Introductory text \\
\hline & & & $\begin{array}{l}\text { 2. Cyclic stress- } \\
\text { strain curves }\end{array}$ & $\begin{array}{l}\text { HTML tabs with links to embedded graphs, } \\
\text { data tables, and stored processes that support } \\
\text { data downloads. }\end{array}$ \\
\hline & & \multirow[t]{2}{*}{$\begin{array}{l}\text { Tensile } \\
\text { tests }\end{array}$} & $\begin{array}{l}\text { 1. Introduction to } \\
\text { tensile testing }\end{array}$ & Introductory text \\
\hline & & & $\begin{array}{l}\text { 2. Baseline strength } \\
\text { tests }\end{array}$ & $\begin{array}{l}\text { HTML tabs with links to embedded graphs, } \\
\text { data tables, and stored processes that support } \\
\text { user-specified graphics and data downloads. }\end{array}$ \\
\hline
\end{tabular}

These tables show that the content in most of the portlets is text, graphs, links to graphs, or icons that are links to reports. The reports generally provide tabulated data that is available for users to download. The graphs facilitate comparisons and evaluations of the data. The different types of portlets and their capabilities for displaying data are discussed from two perspectives in Section 3. First, they are presented from a general level. Then they are discussed specifically as the capabilities are used in the NDMAS portlets. Tables in Appendix B provide more detail about the contents of the portlets.

\subsubsection{Data Analysis and Web Delivery Capabilities for the NDMAS Team}

The NDMAS team has direct access to the data in the SQL database, called the "Vault." Data sets judged most useful are shown in the INL NDMAS web portal, but all the data in the system are accessible to the NDMAS development team.

The data are stored in NDMAS as described in Figure 3. The vast majority of the data enter the system from electronic records such as text files or Excel spread sheets. In Figure 3, these are schematically shown as "Raw data files." Enterprise Guide (EG) is a tool provided by SAS for data manipulation and analysis. Transforming includes such processes as introducing standard date-times and units. "Projects" have been created in EG to process each data stream and load it into the SQL Vault. The Vault provides for data security and change control. 


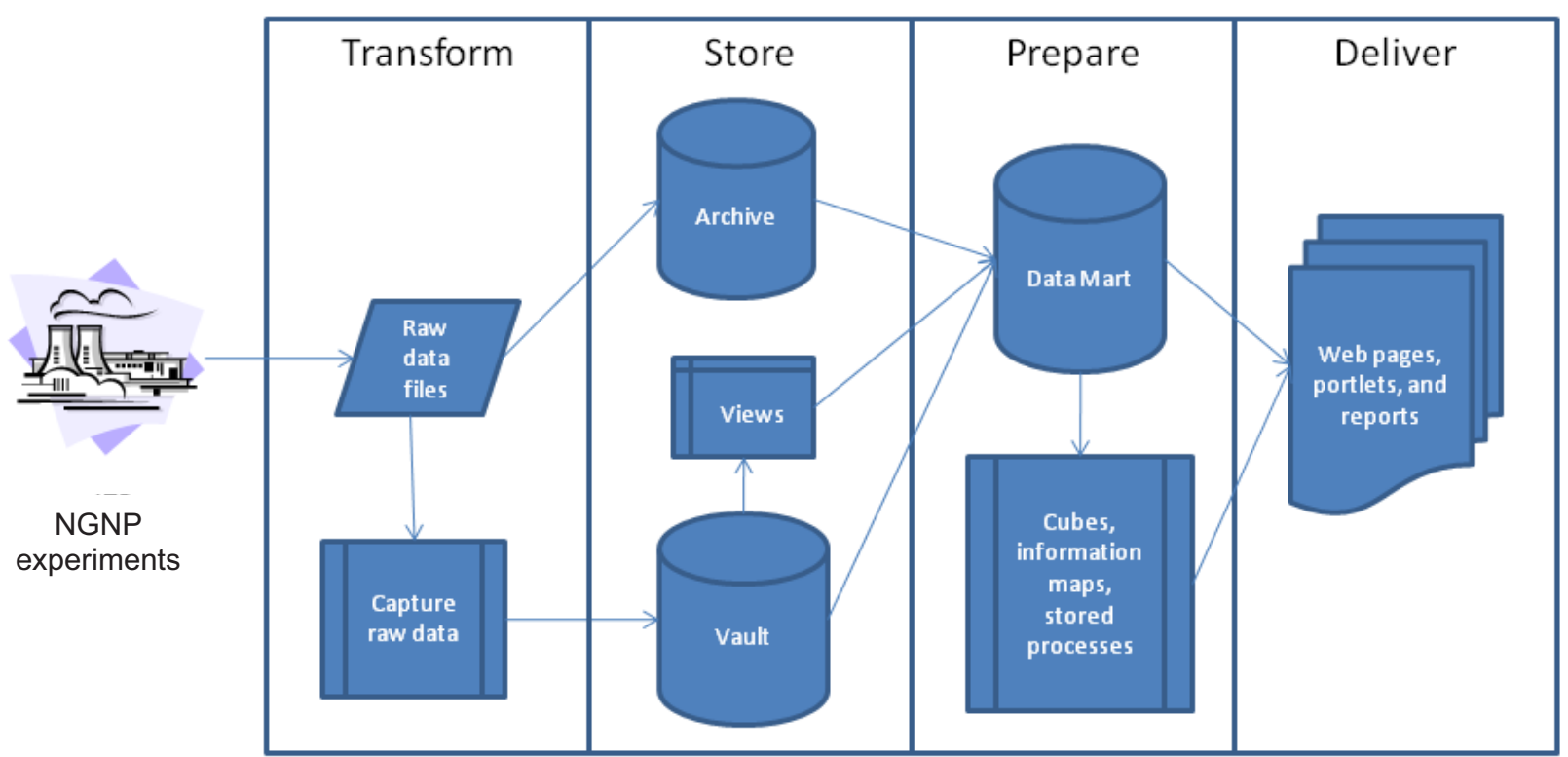

Figure 3. Four major steps in NDMAS data processing.

NDMAS developers extract the data from the Vault as tables, generally with multiple measurements in each record such as experiment parameters (e.g., temperatures and gas flows) in a particular capsule or sample at a specific point in time.

\subsubsection{Data Analysis and Web Delivery Capabilities via Analysis Requests}

The ready-to-download data tables and analysis results in the web pages are structured based on the best knowledge of NDMAS staff. The most detailed levels of data for some of the VHTR projects contain millions of records. Web display of detailed data (such as individual 5-minute temperature readings) is not practical because the time required for such displays to render would be prohibitive. However, users who need particular studies to be performed using the VHTR data can request these analyses from the NDMAS staff.

In addition to making new or different calculations with the most detailed data, the requests may involve combining different types of data from different data streams. The data streams from various sources are organized in NDMAS in a linkable manner based on specific component, variable, and data package identifiers. An example of this linking is the joining of AGR-1 fuel fabrication data with the physics simulated data describing conditions at the end of the experiment. The average fuel temperatures, burnup, and fluence data for each compact were associated with the compact's fabrication identifier. The traceability of attributes from the PIE data to the fabrication data is also preserved.

Results can be displayed on the INL NDMAS web portal and/or in reports, as desired by the person making the request. For the reports displayed in the portal, user group security options may be employed to restrict access if needed. Data analysis reports can thus be distributed to particular users on the Internet based on assigned groupings.

\subsubsection{Data Analysis Capabilities via Downloads}

The INL NDMAS web portal provides several options for downloads of the data (see Section 3). Users can also request particular data sets and the NDMAS team will deliver them (pending appropriate release approvals). The results can be in Excel spreadsheets or many other formats, as desired by the user. 
Such data can be combined by the user with other data and used for data analysis to further the state of VHTR research in whatever way the user has in mind.

\subsection{Uses of the Applications}

NDMAS data analysis and web display capabilities have many potential uses, including the following:

- To increase scientific understanding (a fundamental reason for any attempt to identify relationships between variables).

- To visualize data, especially in web page outputs. Data visualization helps researchers grasp the patterns in the observed data. In the web pages, these patterns are distilled from sometimes thousands of records.

- To provide accuracy tests for input data streams. Accuracy tests are a current use for many of the analyses. Some of the tests are based on simple calculations, such as the idea that the coefficient of variation (the standard deviation divided by the mean) should remain within certain bounds. Others are based on functional relationships established by a regression analysis. Once a pattern has been established, significant deviations from the pattern give rise to alerts for increased data review. Such deviations either indicate errors in the data collection process, or significant changes in experimental conditions.

- To provide alerts or early warnings of possible anomalies or instrument failure based on departure from prior patterns. Such alerts can be useful during the experiments. In some cases, experimental conditions can be adjusted or corrected as a result of the accuracy tests. The timeliness of data processing in NDMAS also facilitates this potential use of the analyses and web monitoring displays.

- To provide information to assist in experiment control after instrument failure.

- To develop and evaluate hypothesis tests using the experimental results. The tests can help identify the features of the experimental design that make a difference, or the features that lead to the best performance. Random variation is always present. The statistical analyses can help distinguish whether the measurement results of one process are really likely to be an improvement over the measurements from a different process, even in the presence of this variation.

- To help identify operating limits for safe operation.

- To characterize reliability, given particular operating limits.

- To develop response surfaces that allow users to estimate future phenomena based on operating conditions that have been studied in prior ATR reactor cycles or VHTR experiments.

- $\quad$ To support VHTR licensing. 


\section{WEB DELIVERY CAPABILITIES}

In the first section below, selected SAS Enterprise Business Intelligence (EBI) features related to web page capabilities are described. The following section shows how these capabilities are used in the current NDMAS web site.

\subsection{SAS Web Page Display Capabilities}

NDMAS uses the SAS EBI platform to deliver experimental results from VHTR data generators to the community of interested stakeholders over the Internet. The results are delivered in two primary forms: downloadable data tables, and graphs. However, many details and subtleties are considered in the process of developing web page content. Considerations include the nature of the data being displayed, the types of tabular data that would be useful, the grouping of the data so that vast amounts of data can be shown in an organized presentation, and the types of graphs or other displays that would facilitate display and understanding of the data. Finally, after individual pieces of content are developed, the overall layout in the web page must be specified. These topics are discussed below.

\subsubsection{Web Page Purpose}

Prior to development of a web page, data from a VHTR experiment must be received and entered into the NDMAS data base. This process requires an understanding of the nature of the experiment being performed and the measurements being taken. Attribute data are gathered to describe the experimental units or samples being studied. Some experiments are conducted and all the resulting data are submitted at once, while other experiments are conducted over a long period of time and have ongoing data with time stamps. Some experiments are part of a series (e.g., AGR-1, AGR-2...). In this case, the NDMAS data stream manager considers how many experiments will be performed and the defining attributes that characterize each experiment. Relationships between experiments are considered in developing a data structure that spans all the results and puts them in an understandable context.

From this understanding of the experiments, the designer picks a focus for each web page. Each web page has a purpose or requirement that governs its development. In NDMAS, the first step in creating the web pages is developing requirements for presenting experimental results in a complete context that facilitates their understanding.

\subsubsection{Three Types of Data and Two Types of Data Sources}

In the SAS EBI framework, like any other data system, data may be either numeric or text. The numeric data are "measures" and the text variables are "categories." However, SAS has a third type of variable, namely, "hierarchy" variables. Hierarchy variables are variables that form the basis for defining subsets of data and possibly subsets of data nested within those subsets. Examples of hierarchies include projects with tasks, sampling groups with samples, or averages with detailed individual measurements. Time hierarchies can go from year to month to day to hour, and so forth.

A variable becomes a hierarchy variable when it is used as a dimension in a special data set called a multidimensional data set or "cube." Ordinary data sources are just tables, with rows and columns of related information. In the unique SAS EBI framework, such tables are called "relational" tables. A cube or multidimensional data source, on the other hand, has one or more hierarchy variables that define its dimensions. When the cube is constructed, SAS considers all nested or crossed combinations of the hierarchy variables and constructs aggregations that allow the data to be consolidated as desired by a user from the web page without repeating the calculations. It then displays the aggregated data at the top of the pyramid. The user can "drill down" as desired to see the more detailed layers of the data. The cube 
designer specifies, for each numeric (measure) variable, how the data are to be aggregated or combined when it is grouped according to the hierarchy variables. It could be an average, or a sum or count, or one of several other summary functions.

The definitions of the three types of data (categories, measures, and hierarchy variables) and the two types of data sources (relational and multidimensional) are summarized in Table 5.

Table 5. Data field and data source types.

\begin{tabular}{lcl}
\hline $\begin{array}{c}\text { Standard Data } \\
\text { Field Types }\end{array}$ & Icon & \multicolumn{1}{c}{ Definition } \\
\hline Measure & & $\begin{array}{l}\text { Numeric; ordinal (may be discrete, or may be continuous, "interval" } \\
\text { data). Includes binary data. }\end{array}$ \\
Category & $\begin{array}{l}\text { Classification variable. Text. May have a natural ordering (nominal). } \\
\text { Includes time variables. }\end{array}$ \\
$\begin{array}{l}\text { Hierarchy (cube } \\
\text { dimension) }\end{array}$ & Classification variable or time entity (days, hours) nested within a \\
Data Source Types & Icon & \multicolumn{1}{c}{ Definition } \\
\hline Relational & (None) & $\begin{array}{l}\text { A table, or a data set constructed from an information map that looks } \\
\text { like a table. There are no hierarchy fields. }\end{array}$ \\
$\begin{array}{l}\text { Multidimensional } \\
\text { (Cube) }\end{array}$ & $\begin{array}{l}\text { A cube is a data set containing a set of nested categorical fields. The } \\
\text { nesting forms a defined hierarchy. Each numeric field in the data set } \\
\text { is assigned a default aggregation method. The data set includes } \\
\text { summary data for various aggregations that could be formed using } \\
\text { the hierarchy variables. A cube always contains at least one hierarchy } \\
\text { data field. }\end{array}$ \\
\hline
\end{tabular}

\subsubsection{Two Types of Tabular Displays}

Tabular data displays are used on the NDMAS web portal primarily to support data downloading by users. The two types of tabular displays are lists and cross-tabulations (cross-tabs). Relational data sources can generally be displayed either way, but cubes are always cross-tabs.

Lists display detailed data at the level of data table records. For cross-tabs, on the other hand, the data are grouped and summarized. Cross-tabs are like Pivot Tables in Microsoft's Excel application. Table 6 provides examples and further definitions of these terms.

\subsubsection{Methods for Grouping Data in SAS Reports}

SAS reports are one of the primary methods used on the NDMAS web portal to display and deliver data. These reports use SAS data sets and Information Maps to create professional data displays that include automatic updates, security, and user tools to manipulate the data on-line (e.g., filtering, sorting, plotting). A portion of a SAS report showing a data source with irradiation fission product release data is shown in Figure 4 (a). The Table of Contents and Section Data panels on the left can influence the data content the right. In the current example, which provides data for ATR cycle 148A, the Table of Contents is not used. Clicking on the Options in the Section Data sections allows the viewer to select the columns in the display. The icons next to the variables show their type.

In Figure 4 (a), the data are split by ATR cycle but the selection of the cycle of interest is in the portlet launching the report [Figure 4 (b)]. A second choice is to create "group breaks" in the report. 
Table 6. Report tabulation types.

Report

Tabulation

Types

Definition

Appearance of headings

\begin{tabular}{|c|c|c|c|c|}
\hline \multirow[t]{4}{*}{ List } & \multirow{4}{*}{$\begin{array}{l}\text { Shows details. } \\
\text { Generally not } \\
\text { applicable for } \\
\text { cubes. Table has } \\
\text { column headings or } \\
\text { row headings, but } \\
\text { not both }\end{array}$} & $\begin{array}{l}\text { Atr } \\
\text { Cycle }\end{array}$ & 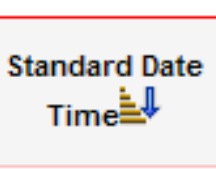 & Capsule $\overline{\overline{=}} \rrbracket$ \\
\hline & & $148 \mathrm{~A}$ & 19AUG10:09:47 & Capsule 6 \\
\hline & & $148 \mathrm{~A}$ & 25AUG10:13:07 & Capsule 6 \\
\hline & & $148 \mathrm{~A}$ & 25AUG10:21:08 & Capsule 6 \\
\hline
\end{tabular}

\begin{tabular}{|c|c|c|c|c|c|c|c|}
\hline \multirow{13}{*}{$\begin{array}{l}\text { Cross- } \\
\text { tabulation } \\
\text { ("Crosstab") }\end{array}$} & \multirow{13}{*}{$\begin{array}{l}\text { Data are } \\
\text { summarized based } \\
\text { on one or more } \\
\text { categorical fields } \\
\text { (for relational data) } \\
\text { or one or more } \\
\text { hierarchy levels } \\
\text { (for cubes). In the } \\
\text { table, "measure" } \\
\text { fields can be in the }\end{array}$} & \multirow[b]{2}{*}{ LEU } & \multirow[b]{2}{*}{ Measurand } & & \multirow{2}{*}{ Mean Value } & \multirow{2}{*}{ Number } & \multirow{2}{*}{ Standard Deviation } \\
\hline & & & & & & & \\
\hline & & \multirow{10}{*}{08} & Aluminum content & $\mu \mathrm{g} /$ compact & 37.98 & 16 & 14.16 \\
\hline & & & Calcium content & $\mu \mathrm{g} /$ compact & 41.28 & 16 & 15.51 \\
\hline & & & Chromium content & $\mu \mathrm{g} /$ compact & 0.49 & 16 & 0.08 \\
\hline & & & Cobalt content & $\mu \mathrm{g} /$ compact & 0.116 & 16 & 0.003 \\
\hline & & & $\mathrm{Cr}+\mathrm{Mn}+\mathrm{Co}+\mathrm{Ni}$ content & $\mu \mathrm{g} /$ compact & 1.36 & 16 & 0.09 \\
\hline & & & Iron content & $\mu \mathrm{g} /$ compact & 3.07 & 16 & 0.4 \\
\hline & & & Manganese content & $\mu \mathrm{g} /$ compact & 0.12 & 16 & 0.02 \\
\hline & & & Nickel content & $\mu \mathrm{g} /$ compact & 0.64 & 16 & 0.03 \\
\hline & & & $\mathrm{Ti}+\mathrm{V}$ content & $\mu \mathrm{g} /$ compact & 19.89 & 16 & 1.82 \\
\hline & & & Uranium loading & g/compact & 0.982 & 6 & 0.003 \\
\hline & & & Aluminum nantant & Harlanmmant & 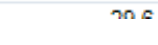 & 18 & 244 \\
\hline
\end{tabular}

column titles, but not both. Category fields may be in both the row and column variable lists. The table cells contain the aggregated summary values of selected measures at the intersection of the row and/or column categories

From a relational table (AGR-2 FAB, "Compact Impurities") The first three columns are shaded and define the rows.

\begin{tabular}{|c|c|c|}
\hline & $\begin{array}{c}\text { IPyC Mean } \\
\text { Diattenuation } \\
\text { precompacted }\end{array}$ & $\begin{array}{l}\text { IPyC St Dev } \\
\text { Diattenuation } \\
\text { precompacted }\end{array}$ \\
\hline 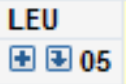 & & \\
\hline$\boxplus$ 甲 08 & $\underline{0.01756}$ & $\underline{0.00351}$ \\
\hline$\oplus \square 09$ & $\underline{0.01164}$ & $\underline{0.00194}$ \\
\hline$\boxplus$ 国 11 & $\underline{0.01114}$ & $\underline{0.00244}$ \\
\hline
\end{tabular}

From a cube (AGR-2/FAB/Anisotropy)

An option allows these to be placed on separate pages. The Table of Contents area then allows the user to select particular values of the grouping variable [see Figure 4 (c)]. Still another way to separate the data when designing a report is to create new sections. Sections are accessed using the drop-down arrow by the small window under Table of Contents, or by clicking on the box on the far right side of the report menu bar. Sections can differ by showing different groups, can show a different set of variables from a wide data set, or can display completely different tables. Figure 4 (d) is an example of section use. Group breaks and sections can be used together. 


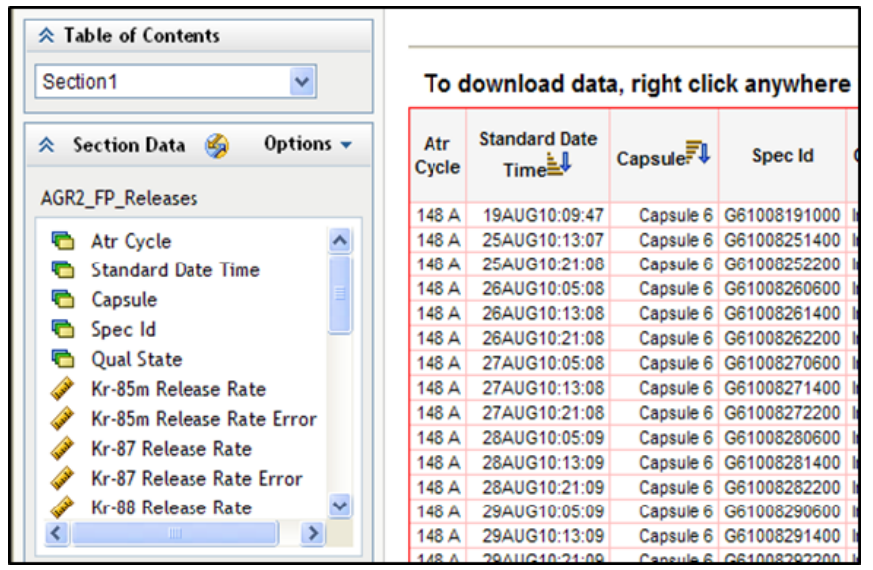

(a) No use of group breaks or sections

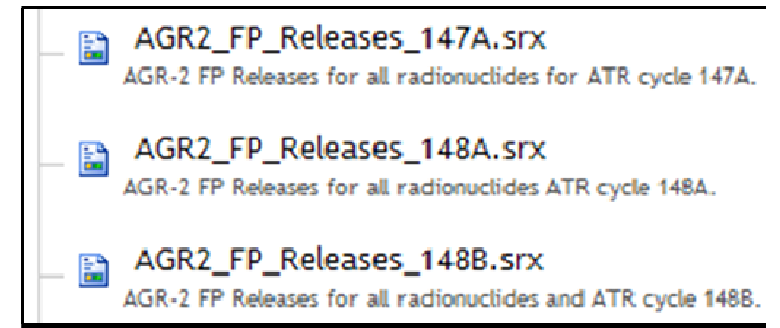

(b) Grouping via separate reports with links in collection portlet

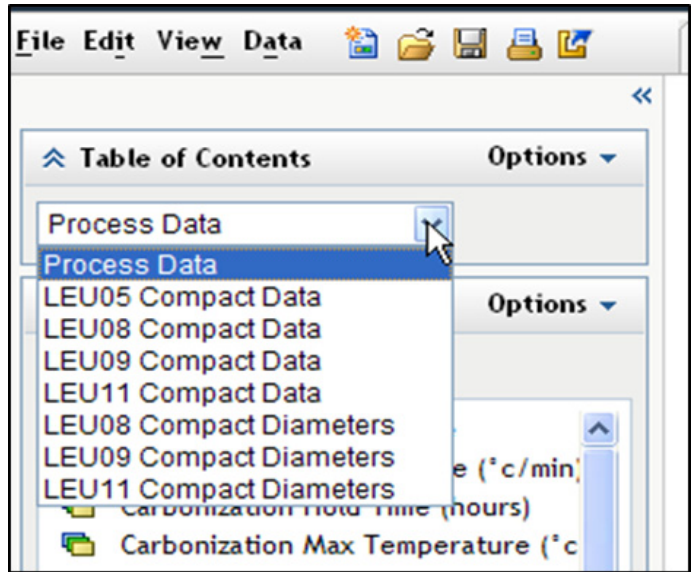

(d) Use of report sections.

(c) Use of group breaks with new page for each

Sunday, August 28, 2011 12:36:46 AM MDT ATR Cycle : $145 \mathrm{~A}$

\begin{tabular}{|l|c|c|r|r|}
\hline $\begin{array}{l}\text { Project } \\
\text { Name }\end{array}$ & $\begin{array}{c}\text { ATR } \\
\text { Mode }\end{array}$ & $\begin{array}{c}\text { Standard Date } \\
\text { Time }\end{array}$ & $\begin{array}{c}\text { Effective } \\
\text { Power }\end{array}$ & $\begin{array}{c}\text { Chan1 } \\
\text { Comp } \\
\text { Stress }\end{array}$ \\
\hline AGC-1 & Out & 04SEP09:00:00:00 & 0.0 & -12.6 \\
\hline AGC-1 & Out & 04SEP09:12:00:00 & 0.0 & -12.4 \\
\hline AGC-1 & Out & 05SEP09:00:00:00 & 9.9 & -1.0 \\
\hline AGC-1 & Full & 05SEP09:12:00:00 & 22.1 & 0.7 \\
\hline AGC-1 & Full & 06SEP09:00:00:00 & 22.5 & 255.8 \\
\hline AGC-1 & Full & 06SEP09:12:00:00 & 22.4 & 367.7 \\
\hline
\end{tabular}

Figure 4. Ways to group data in reports (a, b: separate reports; c, group breaks; d, sections).

\subsubsection{Graph Development and Layout Considerations}

The web page designer identifies a set of data to display and makes grouping selections and possibly averages the data or in some other way summarizes it. The next capability to exploit is developing visualizations of data, which generally take the form of graphs. Consideration must be given to what plot traces to overlay together and whether the plot will be a scatter plot, a plot with connected lines, or some other type of plot such as a bar chart, histogram, or box plot. Many other possibilities exist. So the first priority is to select the content and form of the graphs. Beyond these basic considerations, several other capabilities influence the web page graphs, as discussed in sections below.

\subsubsection{Panel and Matrix Graphs}

A graph with several related graphs displayed in separate panels is called a panel graph. The panels may be spread either vertically as rows in the containing graph or horizontally as columns. A graph can contain embedded graphs that spread out in both directions, leading to a matrix with rows and columns of little graphs. SAS tools such as the Graph Template Language (GTL) in Version 9.2 facilitate the development of such displays. The panels form a convenient way to display grouped data. Such data include common attributes across different components (e.g., capsules) and different sets of attributes for a single component. Figure 5 shows examples of these graphs. 


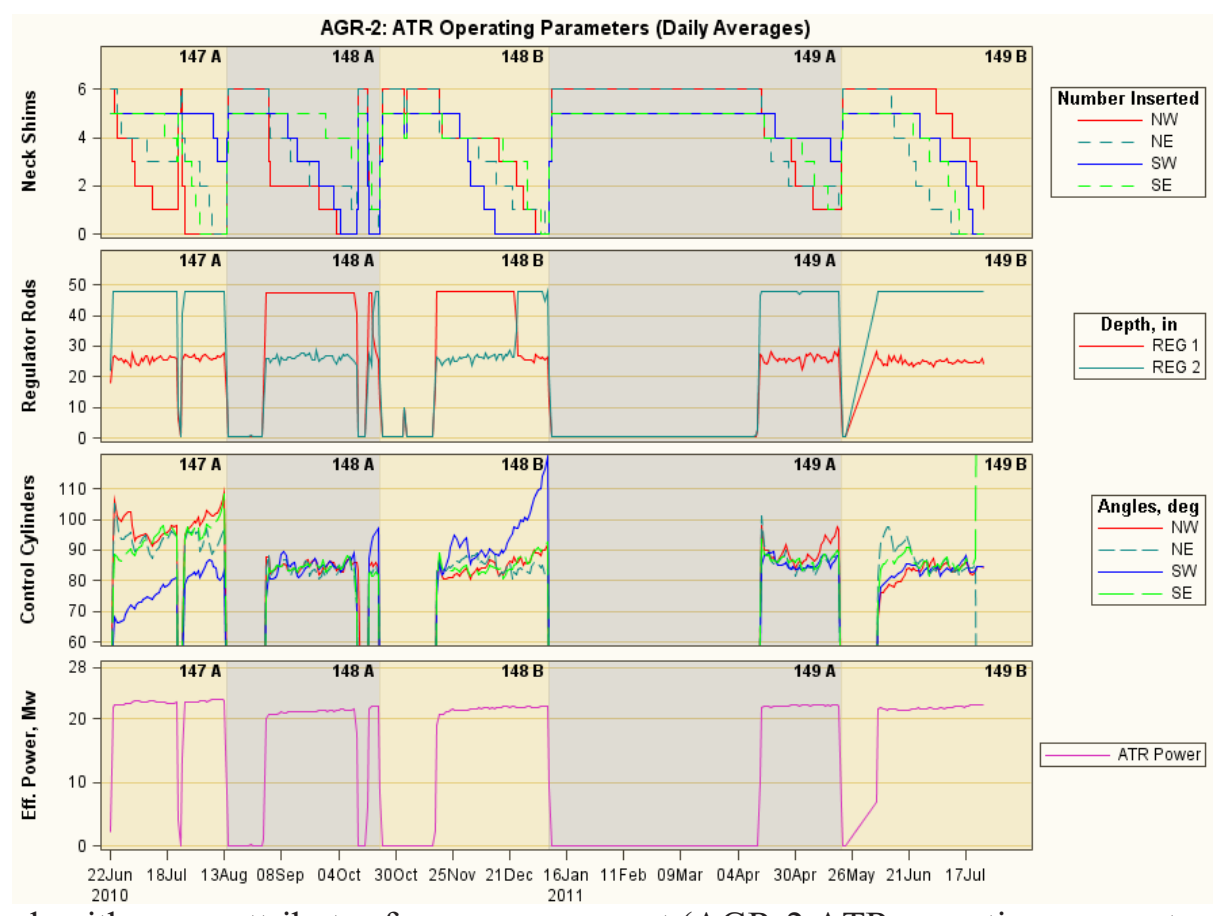

(a) Panel graph with many attributes for one component (AGR-2 ATR operating parameters summary).

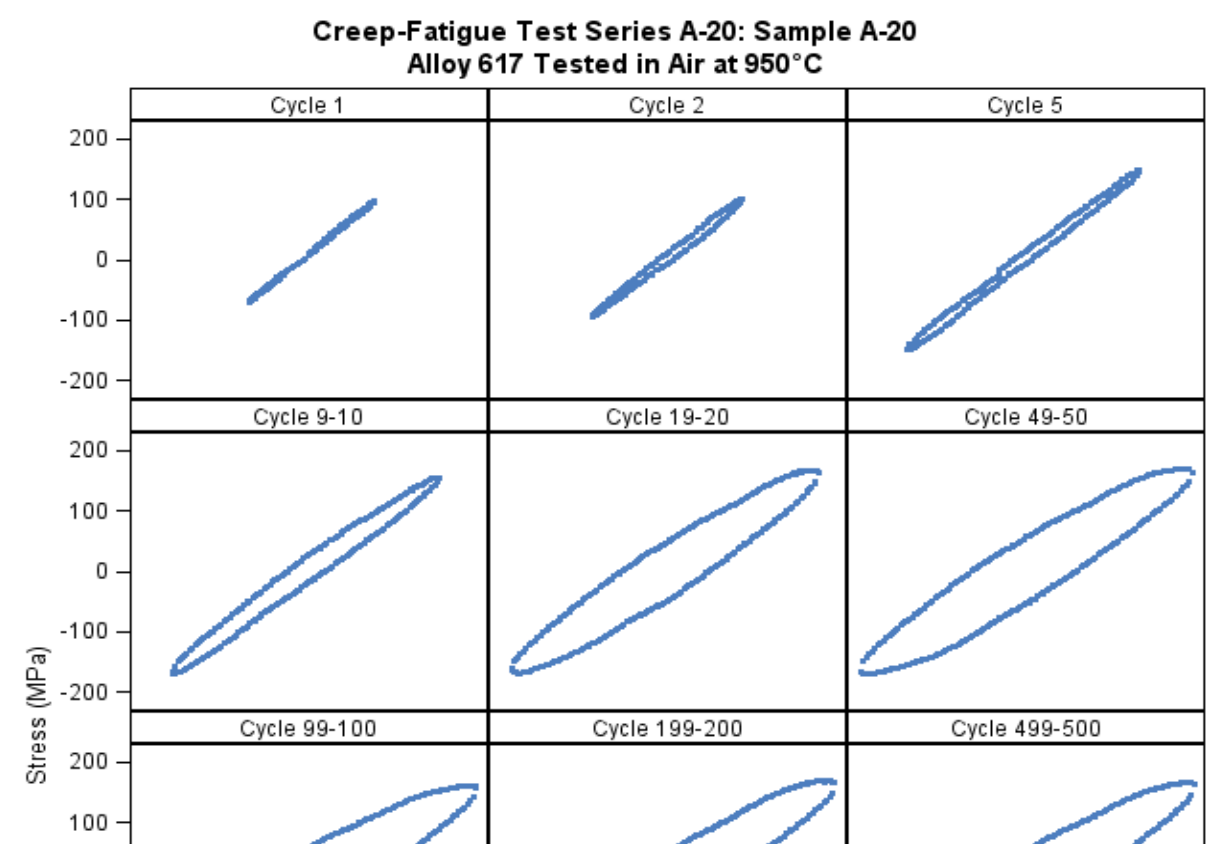

(b) Matrix graph example (high temperature materials cyclic test) [abscissa describes strain $(\mathrm{mm} / \mathrm{mm})$ ].

Figure 5. Panel and matrix graph examples.

\subsubsection{Use of a Background Block Plot}

Another GTL feature that is used in several of the NDMAS web pages is a background block plot. For graphs that show irradiation histories, the abscissa is a measure of time such as an irradiation experiment date or the cumulative number of effective full power days (EFPD) since the start of the experiment. The cycles in ATR also span particular periods of time. Between irradiation periods, adjustments may be made to the experiment or instrumentation. Considering the data on a cyclic basis is 
relevant. The cycle end dates form cut dates for background block displays in many of the irradiation experiment graphs. Figure 5 (a) shows the ATR cycle-based block graph in each panel.

\subsubsection{Timeliness of a Graph}

Many of the graphs on the NDMAS web portal are prepared as ".jpg" files or ".png" files. The HTML file associated with the portlet contains a link to the graph or the graph displays directly as the user scrolls down to its location. These graphs display quickly on the web page, but they are static. If they contain data that needs to be updated, they must be regenerated. A future feature of the NDMAS system will be the use of tools that automate the regeneration when new data are received.

Graphs available in SAS reports are automatically updated when the underlying SAS data set is updated with new or revised data. Another way to have current data displayed in a graph is to create the graph from a SAS stored process. Such graphs are created on the fly using the latest SAS dataset. Although they may take longer to render on the screen, they are current and can be based on specific user requests.

\subsubsection{Whether a Graph Has Active X Controls and/or Tool Tips}

Many of the graphs on the NDMAS web portal have ActiveX controls and "Tool tips." With ActiveX, a user can right click on a plot to bring up a toolbar [Figure 6 (a)] which can then be used to rotate, expand, or subset (zoom in on) a graph. This is a highly useful feature for graphs with large amounts of data. Tool tips bring up useful information on graph data points when the mouse is moved over specific areas of the graph [Figure 6 (b)]. Graphs do not need to have dynamic, updated data to use these features. Both of these features allow a user to quickly interact with or modify a graph thereby greatly expanding the amount of information available.

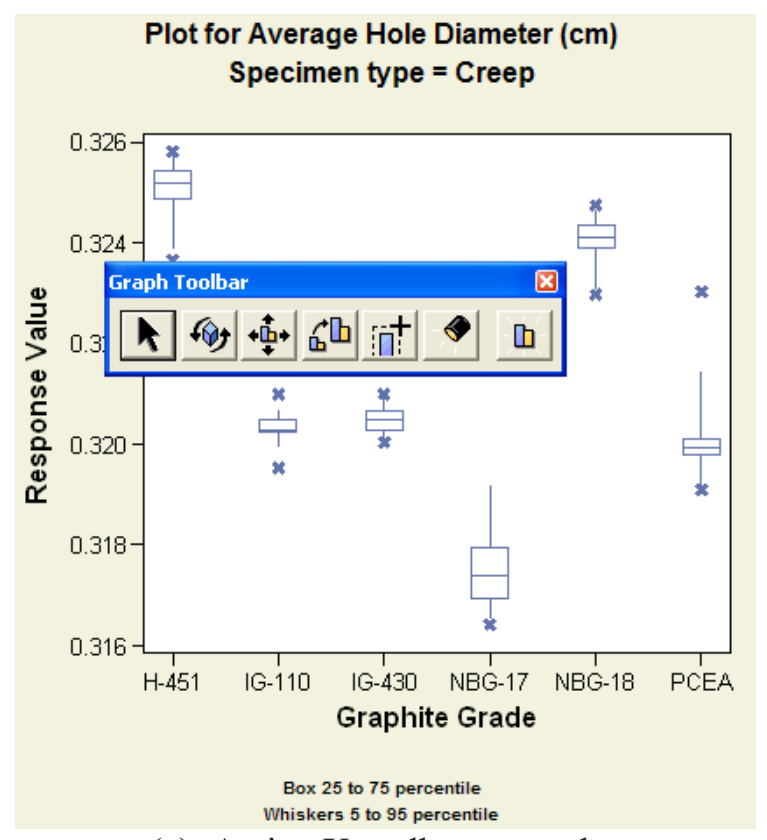

(a). Active $X$ toolbar example.

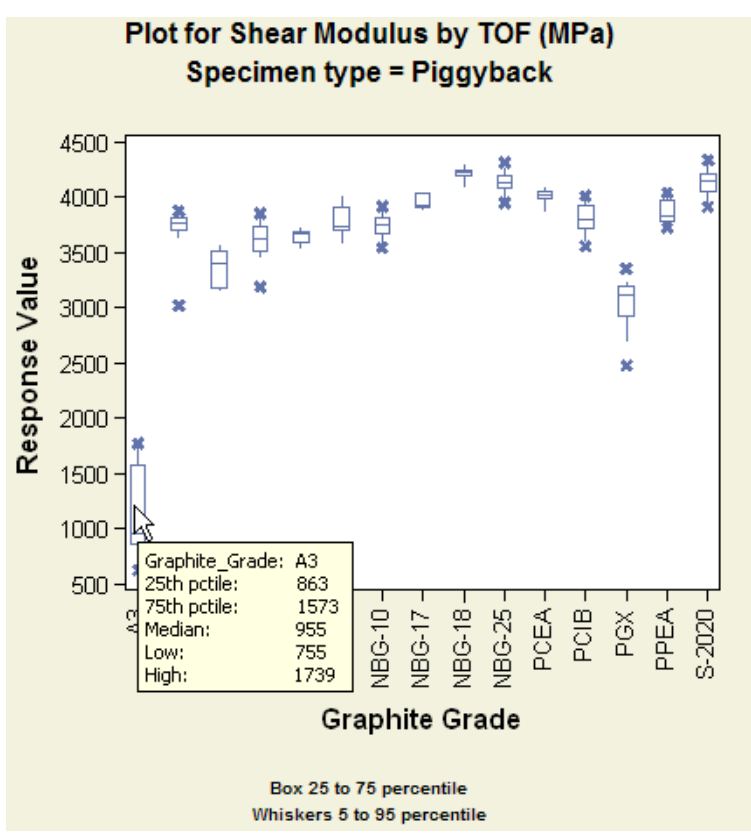

(b) Tool tips example.

Figure 6. Use of Active X toolbar and tool tips. 


\subsubsection{Style Choices Based on Graph Origin}

Most of the graphs are created using SAS's Enterprise Guide interface with the graphic template language. "JMP" is another SAS product that also is capable of making such graphs. The JMP interface is more interactive and the designer can vary the features and select options using a graphical user interface rather than a programming language. The SAS interactive graphic tool is not currently part of the PC workstation NDMAS tools. In any case, there is a slightly different look to the SAS GTL graphs and the JMP graphs (see Figure 7).

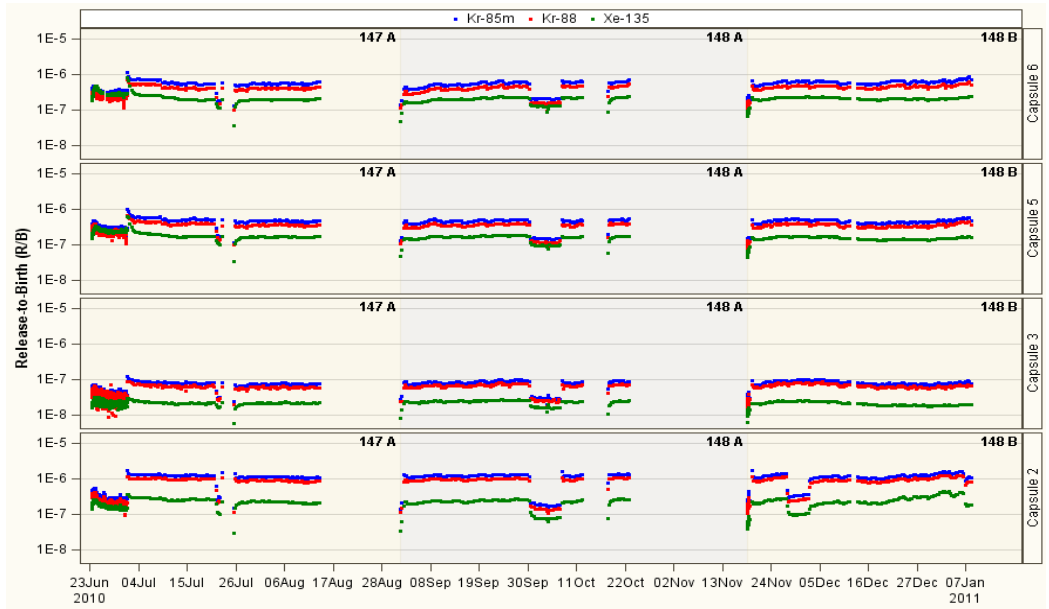

(a). SAS panel graph from AGR-2 fission product monitoring system.

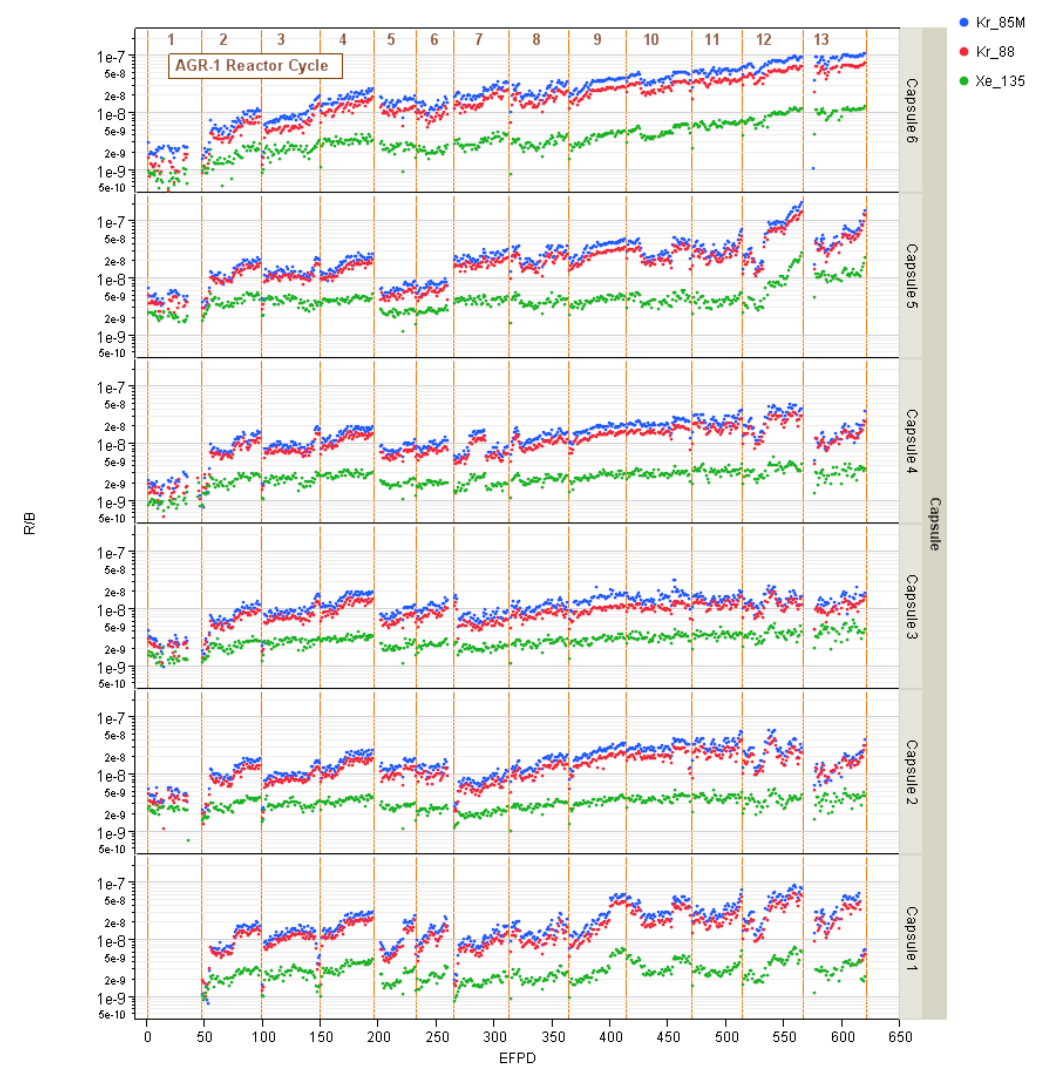

(b). JMP panel graph from AGR-1 fission product monitoring system.

Figure 7. SAS and JMP panel graphs. 


\subsubsection{Summary of Graph Development Considerations}

There are several options in developing a graph, beyond just selecting the data, the form of the graph (scatter plot, bar chart, etc), and style features such as colors and fonts. They are summarized in Error! Reference source not found.

Table 7. Graph characteristics (other than graph form, font styles, colors, etc.).

\begin{tabular}{ll}
\hline \multicolumn{1}{c}{ Characteristic } & \multicolumn{1}{c}{ Possible States } \\
\hline Panels (frames inside frames) & Matrix; panel rows, panel columns, or none \\
Use of background block plot & Yes / no \\
Dynamic data access & "Live," updated, static \\
Active X toolbar & Yes / no \\
Tool tips & Yes / no \\
Plot development origin & SAS EG, JMP, others \\
\hline
\end{tabular}

\subsubsection{Web Page Layout as a Series of Portlets}

After developing web content using detailed or summarized data tables and creating graphs to visualize the results, the actual construction of the webpage occurs. Note that the term "webpage" in this report refers to either the NDMAS information delivery portal, which is specified by a URL (www.ndmas.inl.gov), or to one of the pages that opens when a link from the hierarchy on the left is clicked. The contents of such pages may scroll down several screens. Also, links in those pages may lead to other pages or may open up new windows with additional content, including links to other web sites. In this report, the actions that occur as a user interacts with a web page from the NDMAS portal are considered part of the scope of that "page."

Each web page starts with a portlet that contains introductory text. This portlet may also include figures or HTML tables. Then the web page designer may add one or more portlets with more content related to the theme or purpose of the web page. A consideration in defining the portlets is whether to set them up so that the results show as the user scrolls down the page, or to keep the portlets small and fill them with links to the actual content. Table 8 summarizes some of the capabilities with regard to the portlets. Most of these capabilities are self-explanatory. The linked report, stored process, and HTML file options deserve further comment because they offer additional web display capabilities.

\subsubsection{SAS Report Details}

Options when viewing SAS ordinary reports include menus with user options and the ability for users to edit or customize a report. Also, for cubes, the option to expand or drill down in the report exists. To access these features, the user must click on a SAS report link or click the link above a displayed report table. Note that there also can be static SAS reports that are exported to the web page but not "published" to the part of the SAS EBI system that tracks reports and keeps them linked to actual SAS data sources.

\section{Menus}

The ordinary SAS reports may display the data directly as plots, or display the data in tabulations. When a cube or multidimensional tabulation is displayed, right-clicking in the table reveals the menu of possibilities in Figure 8 (a). In a plot of those data, the menu (b) appears. Part (c) of the figure shows a menu from a list tabulation. All of these menu options are also available from the menu bar above the Table of Contents area on the left side of the report. 
Table 8. Common portlet types used in the NDMAS web pages.

\begin{tabular}{|c|c|c|c|}
\hline $\begin{array}{l}\text { Portlet } \\
\text { Type } \\
\text { and Icon }\end{array}$ & $\begin{array}{l}\text { Portlet } \\
\text { Content }\end{array}$ & $\begin{array}{l}\text { Observed behavior after scrolling } \\
\text { (immediate display) }\end{array}$ & $\begin{array}{l}\text { Observed behavior after clicking } \\
\text { (e.g., follow link in Collection Portlet) }\end{array}$ \\
\hline $\begin{array}{l}\text { Web } \\
\text { page } \\
\text { start }\end{array}$ & Text & $\begin{array}{l}\text { Observe text and possibly figures or } \\
\text { tables as defined in the associated } \\
\text { HTML file }\end{array}$ & Not applicable. \\
\hline URL & $\begin{array}{l}\text { HTML } \\
\text { file } \\
\text { (including } \\
\text { graphs) }\end{array}$ & $\begin{array}{l}\text { Virtually any HTML file can appear } \\
\text { in the portlet, including files } \\
\text { referencing graphs or just more text. } \\
\text { The file can display items in tables, } \\
\text { frames, or tabs. It can display tables } \\
\text { of contents containing links to } \\
\text { additional content. It can launch } \\
\text { stored processes. } \\
\text { When the SAS URL portlet option } \\
\text { "Show full HTML content in inline } \\
\text { frame" is checked, the content } \\
\text { shows immediately as the web page } \\
\text { is scrolled down to the portlet }\end{array}$ & $\begin{array}{l}\text { Clicking the link opens the HTML file } \\
\text { referencing the graph, text, or other } \\
\text { content, in a new window. }\end{array}$ \\
\hline $\begin{array}{l}\text { SAS } \\
\text { report. } \\
\text { 㗐 }\end{array}$ & $\begin{array}{l}\text { SAS } \\
\text { report } \\
\text { (table or } \\
\text { graph) }\end{array}$ & $\begin{array}{l}\text { Displayed report, shows the data } \\
\text { content without clicking on anything } \\
\text { in the web page-just scroll to the } \\
\text { desired content. A link appears } \\
\text { above the displayed table: } \\
\text { c) } 1 \text {. } \\
\text { Clicking on the link leads to the } \\
\text { "after clicking" view, described in } \\
\text { the next column, which has more } \\
\text { options for users. }\end{array}$ & $\begin{array}{l}\text { The link is to a "SAS Report," with a } \\
\text { ".srx" extension. Clicking in the portlet } \\
\text { launches the SAS report process that } \\
\text { accesses the data and opens the report. } \\
\text { SAS reports generally contain } \\
\text { downloadable data. The data may be a } \\
\text { SAS data set or a view of a SAS data set } \\
\text { created as a SAS "Information Map." } \\
\text { Depending on how the report is set up, } \\
\text { the data may appear as a table, or } \\
\text { graph(s) may appear. Elements such as } \\
\text { tables, graphs, or text can be arranged in } \\
\text { rows and/or columns in the report using } \\
\text { the tool that defines it. }\end{array}$ \\
\hline $\begin{array}{l}\text { SAS } \\
\text { stored } \\
\text { process }\end{array}$ & $\begin{array}{l}\text { Stored } \\
\text { process }\end{array}$ & $\begin{array}{l}\text { The menu screen prompting the user } \\
\text { for inputs defining the desired } \\
\text { product appears (if applicable). A } \\
\text { "run" button appears; clicking } \\
\text { invokes the process which creates } \\
\text { output based on the current state of } \\
\text { the underlying data. }\end{array}$ & $\begin{array}{l}\text { Clicking the stored process icon } \\
\text { launches the SAS stored process. }\end{array}$ \\
\hline $\begin{array}{l}\text { Collec- } \\
\text { tion }\end{array}$ & $\begin{array}{l}\text { Any of } \\
\text { above }\end{array}$ & $\begin{array}{l}\text { References to reports, links to } \\
\text { HTML files, references to SAS } \\
\text { stored processes or other web pages } \\
\text { appear in a list. The collection } \\
\text { portlet forms a convenient way to } \\
\text { group related items. The user must } \\
\text { click on the hotspots to bring up the } \\
\text { associated displays. }\end{array}$ & $\begin{array}{l}\text { Shows the content associated with the } \\
\text { selected item. }\end{array}$ \\
\hline
\end{tabular}




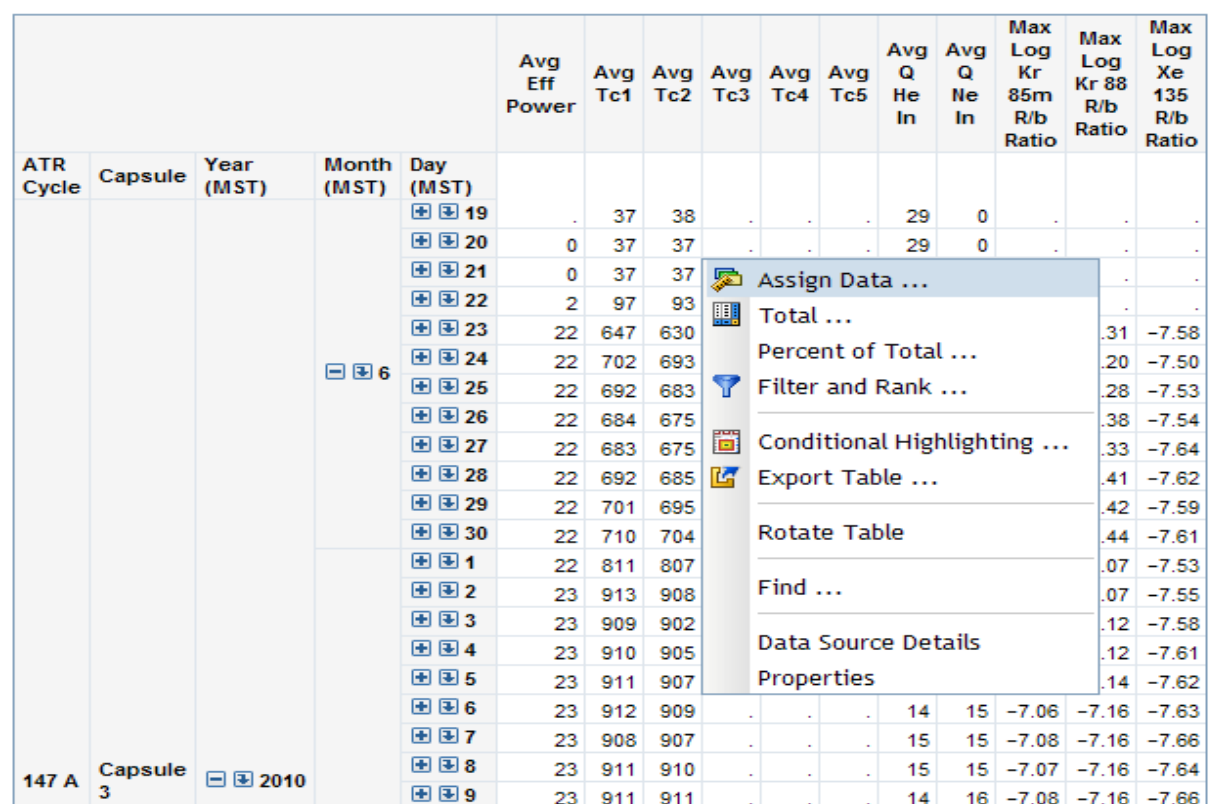

(a) Menu from multidimensional table or "cube" (gas flows in Capsule 3 from AGR-2/IRR page).

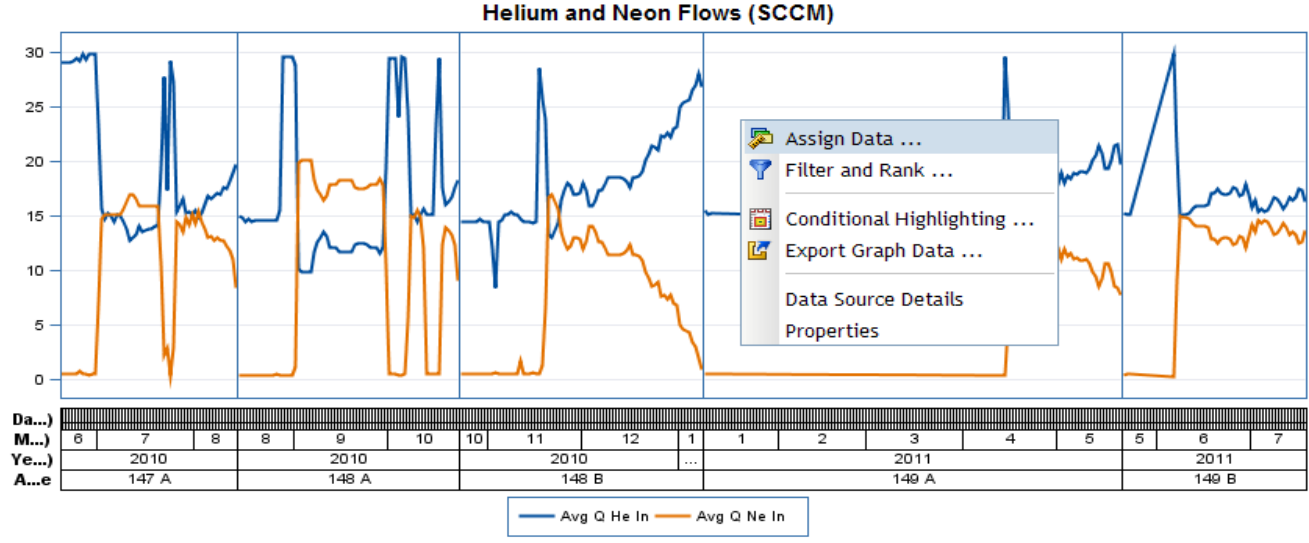

(b) Menu from report graph showing multidimensional data (gas flows in Capsule 3 from AGR-2/IRR).

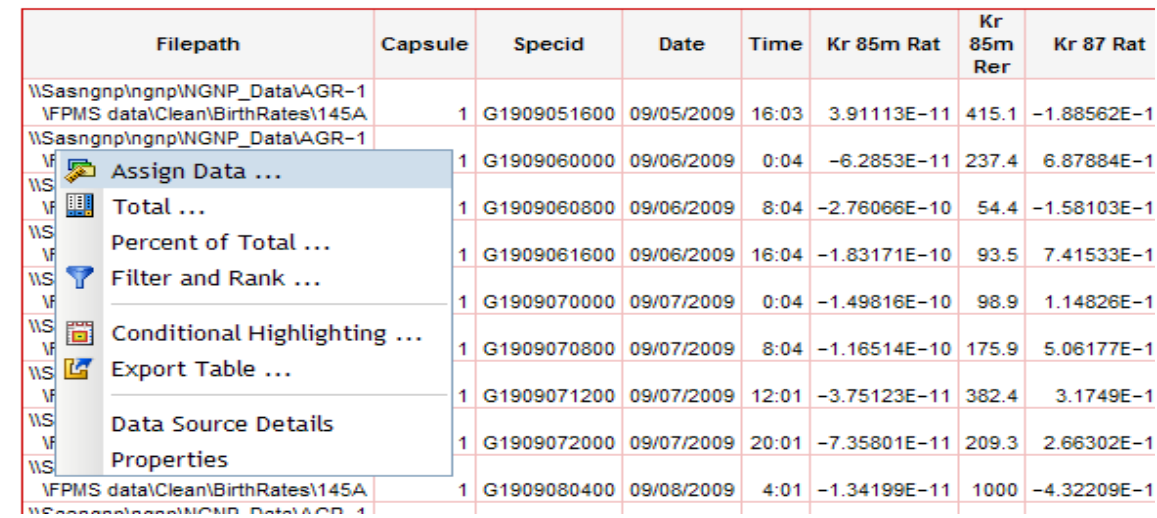

(c) Menu from relational table (AGR-1 R/B ratios from the AGR-1/FPM page. ATR cycle 145A).

Figure 8. SAS report menu options. 
The displays in Figure 8 show that the multidimensional cross-tab has the greatest number of options. Options in the next two frames of the figure are subsets of the options in Part (a). Cross-tabs formed from relational tables have the same options as Part (a) except for the "Find..." option. Table 9 discusses the ten options.

Table 9. Report options after clicking in the text or on a plot.

\begin{tabular}{|c|c|}
\hline Option & Description (option permits or provides...) \\
\hline Assign Data... & $\begin{array}{l}\text { Allows user to move data fields around from row to column, or hide a } \\
\text { data field. Note that the quantities being summarized must be numeric } \\
\text { ("measures") and the fields used to group the data must NOT be } \\
\text { numeric. }\end{array}$ \\
\hline $\begin{array}{l}\text { Total... } \\
\text { Percent of Total... }\end{array}$ & $\begin{array}{l}\text { Add row(s) or column(s) as applicable with subtotals, totals, or } \\
\text { percentages of totals. }\end{array}$ \\
\hline Filter and Rank... & $\begin{array}{l}\text { Filter or order the data based on a categorical variable such as capsule or } \\
\text { ATR cycle. }\end{array}$ \\
\hline Conditional Highlighting... & $\begin{array}{l}\text { Make values larger and bold (or other formats) if they follow specified } \\
\text { rules based on a comparison of a field with a value or with another field. }\end{array}$ \\
\hline Export Table... & $\begin{array}{l}\text { Select a group of rows or all rows or a group of columns or all columns } \\
\text { and export as a tab- or comma-separated value file. Options also exist } \\
\text { for export directly to Microsoft Word or Excel. }\end{array}$ \\
\hline Rotate Table & For cross-tabs, transpose the table with regard to the hierarchy variables. \\
\hline Find... & $\begin{array}{l}\text { For cubes, initiate a search to find an item that may not initially be } \\
\text { visible because it is at a lower level of the hierarchy. }\end{array}$ \\
\hline Data Source Details & $\begin{array}{l}\text { View information such as whether underlying table is relational or } \\
\text { multidimensional. A panel provides information about the variables }\end{array}$ \\
\hline Properties & $\begin{array}{l}\text { View information such as whether the tabulation is a list or cross-tab. } \\
\text { Also allows user to change fonts, colors, and other visual aspects of the } \\
\text { display. }\end{array}$ \\
\hline
\end{tabular}

Additional menus show when the user clicks on the headings at the bottom of the cube graphs on the left, and when the user clicks in the headings for the dimensional variables of the cube tables (see Figure 9). In the plot, the two bottom groups of options relate to the particular variables being plotted. The first group of options in both parts of Figure 9 is very similar and self-explanatory. Many of the other options are listed in Table 9. The user can thus rearrange the table to suit his or her purposes.

\section{Cube Manipulations}

Clicking on a particular item at the bottom of a cube graph or on the icons in a row of the cube table brings up options for viewing more detailed data (see Figure 10). In the graph, drilling down expands the item clicked. For example, the Month 10 drill down shows data for the 31 days of October. After drilling down, clicking on the "Day" heading on the lower left side shows a new menu option (not shown in Figure 9). Clicking on that option, namely, "Up to Month (MST)," brings the display back to its previous more aggregated view. 


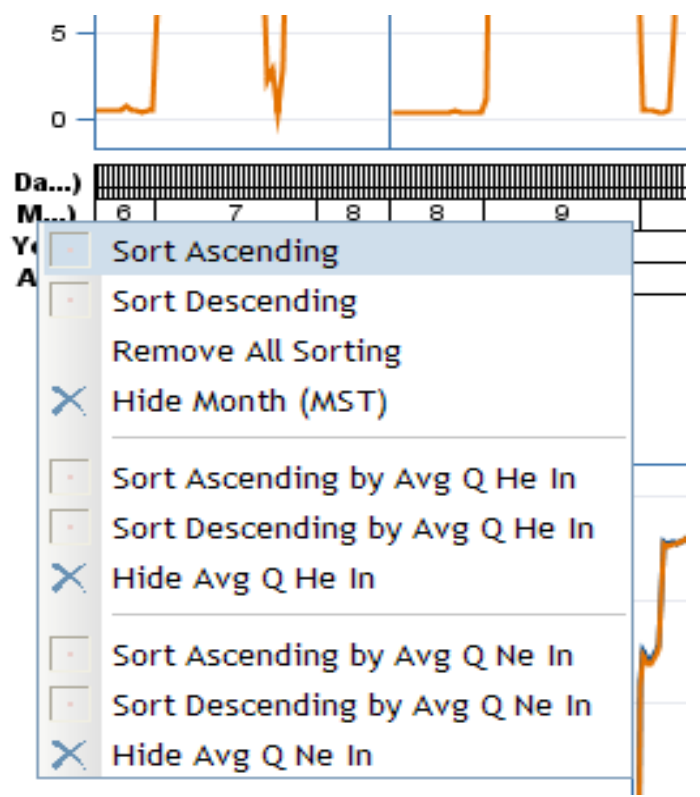

(a) Menu from cube plot heading (bold $\mathrm{x}$-axis heading on left side).

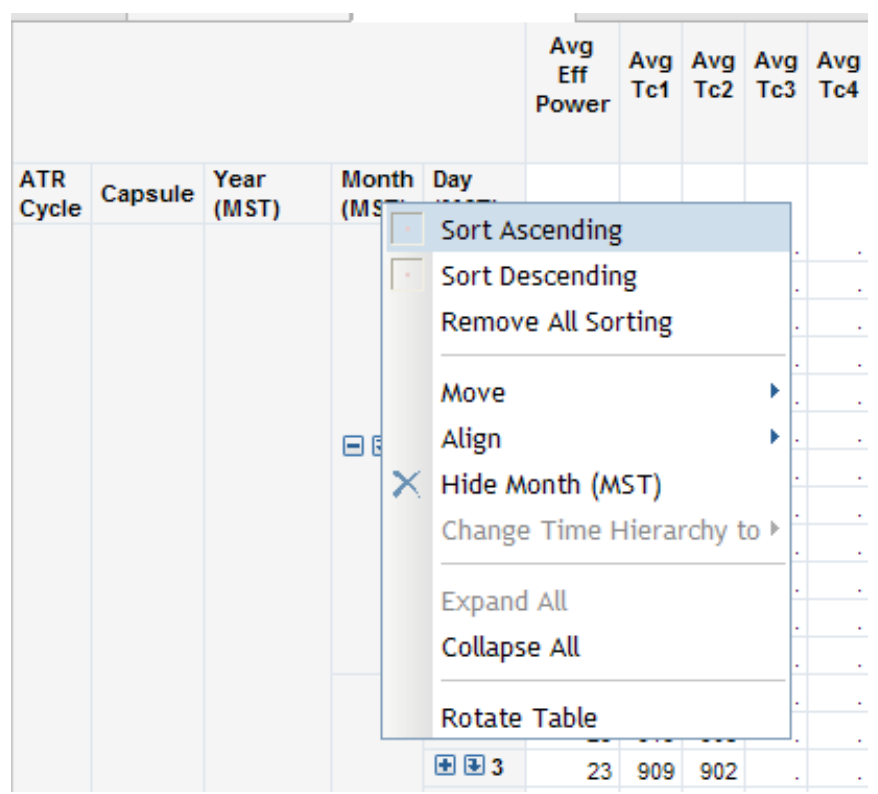

(b) Menu from cube table heading.

Figure 9. Menus after clicking "Month" headings in a report displaying a cube.

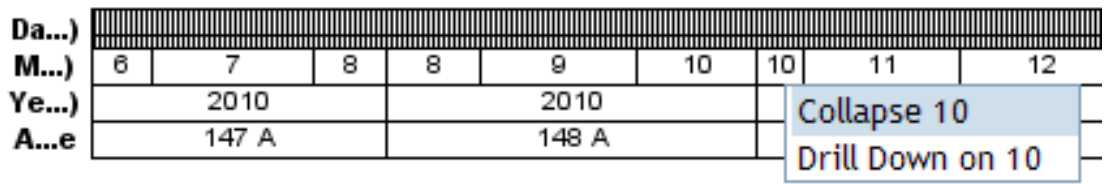

(a) Plot drill-down for month 10

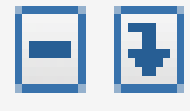

(b) Table selections

Figure 10. Cube plot Collapse/Drill Down options and table Expand/Drill Down icons.

For the table view, the "-" icon causes a collapse and the " $K$ " icon causes the drill down action. Also drill down occurs for the table and the graph both; because they are synchronized. In the table the variable that was drilled no longer appears. However, a hierarchy at the top of the report, such as

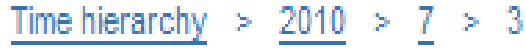

shows the hierarchy path as expanded, with the specific filtered month or day values being viewed. One way to return to more aggregated levels is to click there. Alternately, the collapse option returns the display to higher aggregations in the cube hierarchy.

Another option that occurs in tables is symbolized with a "+" icon. This corresponds to the "Expand" action. The difference between expanding and drilling down is that Expand option does not suppress viewing the rest of the table. Figure 11 shows an expanded view of AGR-2 gas flows in Capsule 3 after expanding July 14, 2010 to show its hourly data. 


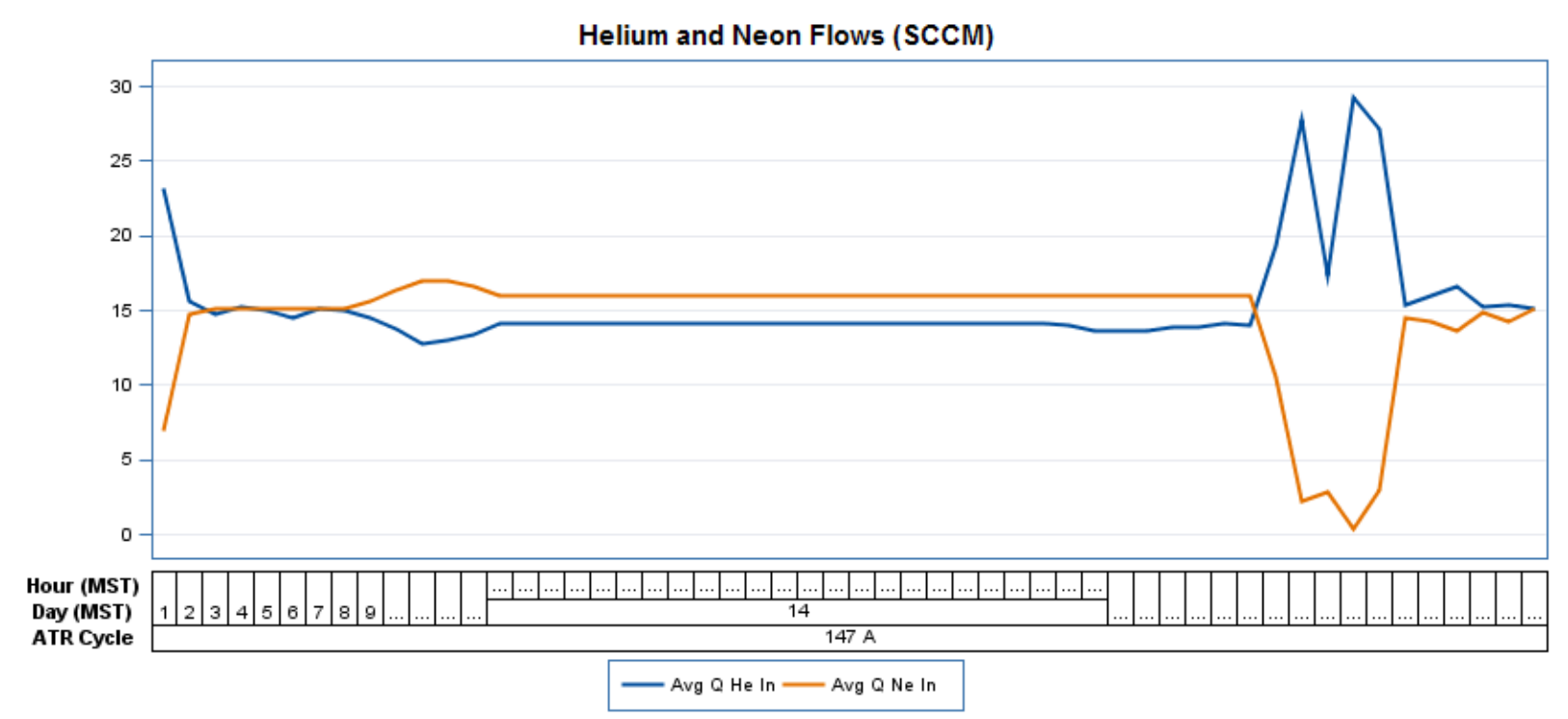

Figure 11. AGR-2 Capsule 3 gas flow rates for July 14, 2010, expanded.

\section{Customized Reports}

The Section Data area on the left side of a SAS report allows users to rearrange the displayed fields and sort and filter the records.

An additional customization possibility is associated with the "Edit" tab that exists next to the open "View" tab at the top of the SAS report window.

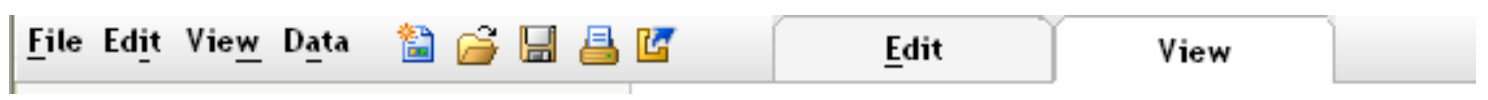

Clicking the Edit tab leads to the "SAS Web Report Studio" environment in which most of the reports are originally built. The user can use the selected data set (named in the "Section Data" part of the viewed report) to construct tables and graphs as desired. The interface allows one to define custom fields. The details of this process are beyond the scope of the current report. The results can be viewed but they cannot currently be saved.

\subsubsection{Stored Processes}

As discussed above, SAS stored processes are useful for producing graphs that show the most current data. However, SAS stored processes can execute virtually any SAS code, including codes for regression analysis or other statistical procedures. In the NDMAS High Temperature Materials web pages, stored processes are used for data downloads and for displaying tabular results. The display and analysis capabilities associated with the SAS stored processes are vast. SAS stored procedures can be invoked from several different places, including a stored process portlet, an SAS report, and via a hyperlink in an HTML file.

\subsubsection{HTML Details}

HTML tags can be used in the web pages to create a variety of data displays. Three examples currently present in the NDMAS web pages are to select box plots for viewing, to select between a series of "tabs" with various data displays, and to select sets of data for downloads. These are illustrated in Figure 12. HTML tags can be used in many other contexts. 

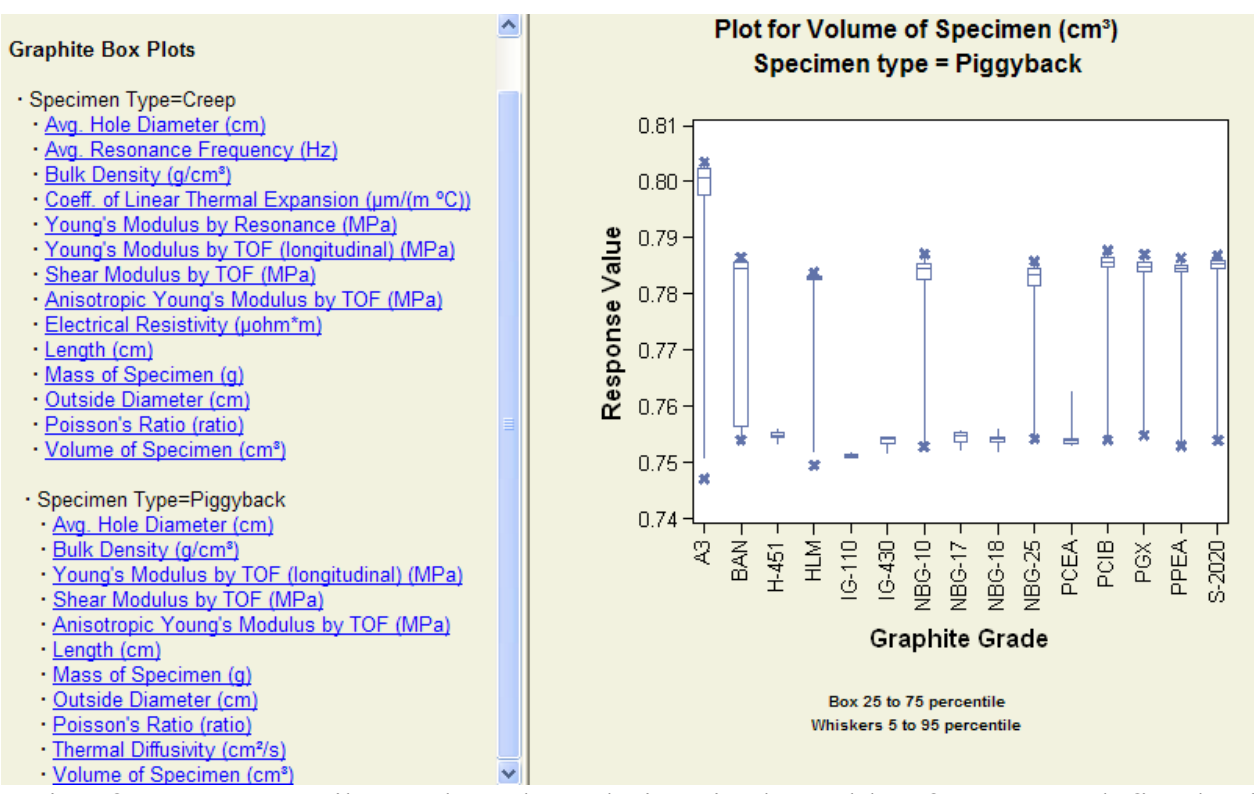

(a) Plot selection for AGC-1 attributes, based on choices in the Table of Contents defined using HTML. Baseline Creep-Fatigue Tests on Alloy 617

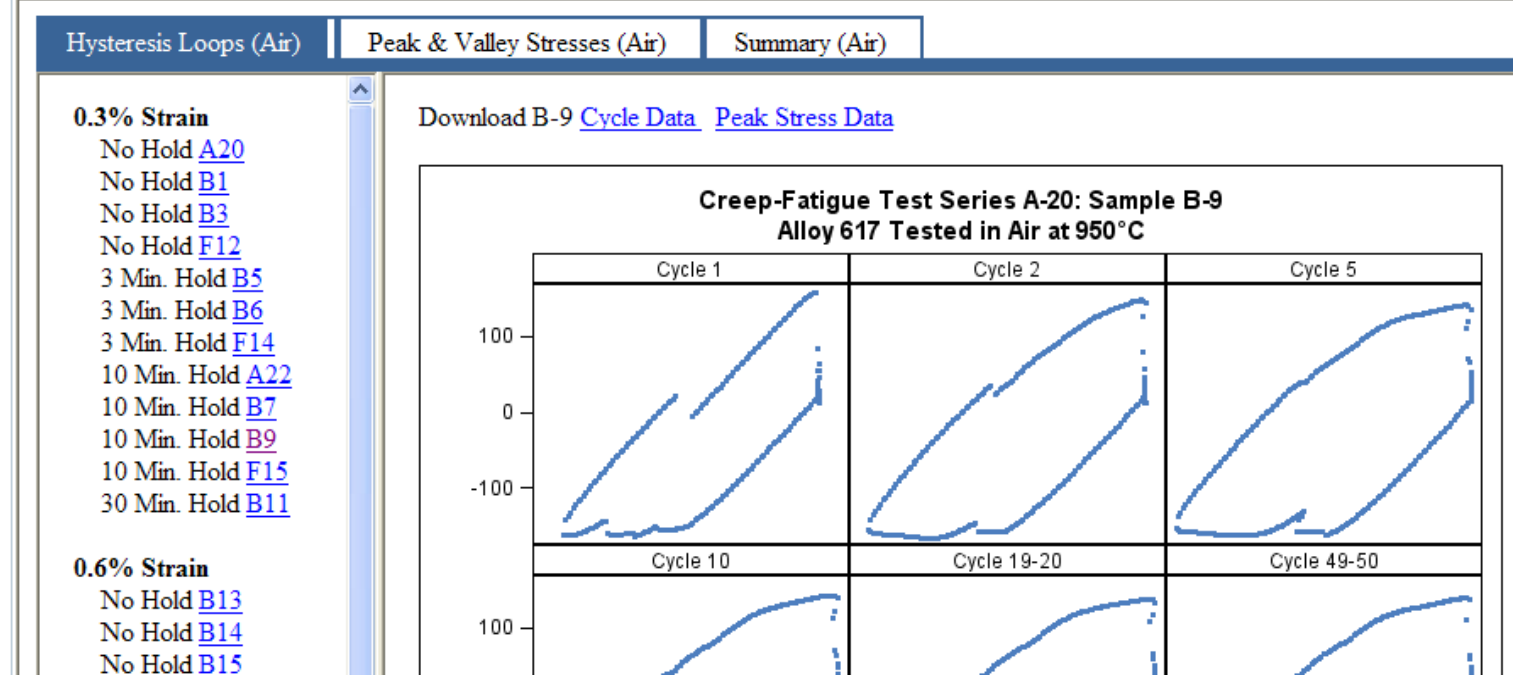

(b) HTML tags used to establish tabs, links to stored processes, and Table of Contents.

\begin{tabular}{|c|c|}
\hline \multicolumn{2}{|c|}{ All A-1 Data } \\
\hline Alloy 617 & Alloy $800 \mathrm{H}$ \\
\hline $\begin{array}{lll}\mathrm{D}-4 & \mathrm{D}-5 & \mathrm{D}-6\end{array}$ & $\mathrm{H}-1 \quad \mathrm{H}-2 \quad \mathrm{H}-3 \quad \mathrm{H}-4$ \\
\hline$\overline{\mathrm{D}-7} \quad \overline{\mathrm{D}-8} \quad \overline{\mathrm{D}-9}$ & $\underline{\mathrm{H}-5} \underline{\mathrm{H}-6} \underline{\mathrm{H}-7} \quad \overline{\mathrm{H}-8}$ \\
\hline$\underline{\mathrm{D}-10}$ D-11 D- & $\underline{\mathrm{H}-9} \quad \underline{\mathrm{H}-10} \quad \underline{\mathrm{H}-11} \quad \underline{\mathrm{H}}-12$ \\
\hline
\end{tabular}

(c) HTML used to select parameter input to the stored process to decide what data to download.

Figure 12. Examples of use of HTML tags for special web displays.

\subsection{Application of Web Display Capabilities in NDMAS}

The experiments currently generating data for the NDMAS portal are briefly described below, along with the types of displays used for each. 


\subsubsection{Experiments with Data}

The display capabilities are currently used in the NDMAS web portal to describe series of tests from three major VHTR research projects.

\subsubsection{AGC Tests}

The Advanced Graphite Creep (AGC) series of experiments is intended to qualify graphite for use in the supporting structures in the core of the proposed VHTR. Various graphite formulations have been characterized. Some will be irradiated in ATR and examined to study performance in a high-temperature, high-neutron-flux environment. Characterization is performed prior to any irradiation, and includes measuring the size of the samples and various properties such as bulk density, elastic modulus, and Poisson's Ratio.

The first experiment (AGC-1) has been completed, and the web pages describe both the characterization data and the irradiation history. Characterization attributes under study for over 400 specimens can be viewed individually or in groups according to graphite project, graphite grade, specimen type (piggyback or creep), and orientation (with or against grain). The data are in a cube structure, which facilitates rapid analysis because the data are hierarchically arranged with pre-calculated summary data at each hierarchy level.

The second AGC experiment (AGC-2) is currently underway. The irradiation history is accumulating, and the AGC-2_IRR web pages are being updated as additional data accrue. The associated characterization data set has not yet been received.

\subsubsection{AGR Tests}

The majority of the data currently stored in NDMAS is associated with the Advanced Gas Reactor (AGR) test series, which is designed to provide data to qualify fuel for the proposed VHTR. The first test was irradiated in the ATR for nearly three years. The irradiation data include fission product monitoring in the capsule offgas. There are also data streams generated before and after the main irradiation experiment. Various properties of the fuel are measured as it is fabricated, and PIE also occurs. A third set of data associated with an AGR test is reactor physics data (Sterbentz, 2010) and heat transfer studies (Hawkes, 2010) that use physics models to predict fuel temperature during irradiation and to predict neutronics characteristics such as fission power and fuel burn-up.

The AGR-2 experiment is currently in ATR. The physics data are not yet displayed because analysis is in progress. Physics analyses are also used to determine isotope birth rates in order to calculate R/B ratios. Of course no PIE data is yet present. As these data streams develop, they will be added to the current NDMAS web portal.

\subsubsection{HTM Tests}

Many stress/strain and related tests are planned to characterize certain stainless steel alloys for use in the reactor pressure vessel and in components such as the steam generator and intermediate heat exchanger. Numerous test series are planned in support of the reactor pressure vessel and the steam generator and intermediate heat exchanger applications. A framework has been developed to store and display these data in NDMAS. Currently, data from seven tests are available on the NDMAS external web site. 


\subsubsection{VHTR Data Display}

The data are presented in the web portal in the same order as the three test series described above. Within a series, topics such as fabrication or characterization precede irradiation topics, and output following an experiment such as the physics modeling and PIE come afterwards. The hierarchical arrangement of the pages facilitates their use. Table 10 provides a cross-linking between the pages in the hierarchy and the web display capabilities described in Section 3.1. It lists display methods and which parts of the hierarchy use them. Tables B-1 through B-4 in Appendix B go through the web hierarchy in the same way as Tables 1-4 above but give a detailed description of each portlet and each reference. 
Table 10. Use of web display capabilities in the NDMAS web portal (excluding qualification pages and portlets, and the introductory text portlets).

\begin{tabular}{|c|c|c|}
\hline Content Type & $\begin{array}{l}\text { Table } \\
\text { type }^{\text {a }}\end{array}$ & NDMAS Use \\
\hline Displayed report & $\mathrm{T}$ & AGR-2/FAB \\
\hline Displayed report with graph rather than table. However, the plotted data are downloadable. & $\mathrm{T}$ & AGR-2/FAB \\
\hline Displayed report with crosstab table & $\mathrm{C}-\mathrm{T}$ & AGR-2/FAB \\
\hline $\begin{array}{l}\text { Displayed report with two "cube" data tables. Crosstab display with averaged data; drill-down to } \\
\text { observe individual measurements. }\end{array}$ & $\mathrm{CCT}$ & AGR-2/FAB \\
\hline HTML frame with links to Active X plots & - & AGC-1/CHR \\
\hline Links to Excel files & - & AGR-1/PIE \\
\hline HTML tabs with links to embedded graphs, data tables, and stored processes for data downloads & T & HTM \\
\hline $\begin{array}{l}\text { HTML tabs with links to embedded graphs, data tables, and stored processes that support user-specified } \\
\text { graphics and data downloads }\end{array}$ & ${ }_{-}^{\mathrm{T}}$ & HTM \\
\hline Displayed panel graph(s) & - & $\begin{array}{l}\text { Home, Analysis, AGR- } \\
2 / \mathrm{GG}\end{array}$ \\
\hline Link: JMP histograms and quantiles and moments by ATR cycle & - & AGR-1/FPM \\
\hline Link: JMP regressions and tables by ATR cycle & - & AGR-1/FPM \\
\hline $\operatorname{Link}(\mathrm{s})$ to graph(s) & - & All IRR, AGR/FTM \\
\hline Reference to report(s) & T & (Many) \\
\hline $\begin{array}{l}\text { Reference to report showing cube (graphite grade }>>\text { specimen type }>>\text { specimen). Cross-tab display } \\
\text { with drill-down capabilities. }\end{array}$ & $\mathrm{CCT}$ & AGC-1/CHR \\
\hline $\begin{array}{l}\text { Reference to report(s) showing cube (capsule, ATR cycle, \& a time hierarchy: Year }>>\text { Month }>> \\
\text { Day }>>\text { Hour). Cross-tab display with drill-downs. }\end{array}$ & $\mathrm{CCT}$ & AGR/IRR \\
\hline Displayed report with crosstab table having 8 sections. & $\mathrm{C}-\mathrm{T}$ & AGR-2/FAB \\
\hline Reference to report, and a link to a HTML graph & $\mathrm{T}$ & AGR-2/FPM \\
\hline Reference to report with group breaks on graphite grade & $\mathrm{T}$ & AGC-1/CHR \\
\hline Reference to report with group breaks on ATR cycle & $\mathrm{T}$ & AGC-2/IRR \\
\hline Reference to report with 3 sections, based on displayed variables. Group breaks on ATR cycle. & $\mathrm{T}$ & AGC-1/IRR \\
\hline Reference to static report with several tables & $\mathrm{T}$ & AGR-1/FAB \\
\hline Link to stored processes that generate graphs as specified by users & $\mathrm{T}$ & All GG \\
\hline
\end{tabular}




\section{EXAMPLES OF CURRENT DATA ANALYSIS APPLICATIONS}

This section contains examples of data analysis applications (rather than web delivery). The development of these applications is an ongoing process. NDMAS will be expanded and sections will be added to future versions of this report as more data streams enter the database and more analyses are performed.

For this version of the report, the following applications are discussed in Section 4: suggested $\mathrm{Ne}$ flow rates for capsules with no working TCs, ability to study impact of gas leakage on Ne fractions, integrating experimental data, TC monitoring, use of the data to identify possible anomalies, use of regression models for sensitivity studies, and potential use of regression models for experiment control.

\subsection{Suggested Neon Flow Rates for Capsules with No Working Thermocouples}

A method has been developed to estimate the neon flow rate for Capsules 2 and 5 in the AGR-2 experiment. The estimate is useful because, since the middle of ATR Cycle 148B (11/27/2010), Capsule 2 has had no operating TCs for experiment control. Capsule 5 has had none since the end of ATR Cycle 149A (5/21/2011). Currently the AGR-2 test has only four capsules with operating TCs.

As ATR fuel depletion occurs toward the end of each ATR cycle, the outer shim control cylinders are rotated to reflect more neutrons. To compensate and maintain stable temperatures in the AGR-2 capsules in spite of the resulting higher fission power densities, the Ne fractions decrease near the end of each ATR cycle (see the pink plot curves in Figure 13). This decrease did not occur at end of Cycle 148B for Capsule 2, and elevated temperatures are likely (see the elevated gross gamma counts for Capsule 2 at the end of Cycle 148B in Figure 14).

The variation in AGR-2 fission powers caused by shim cylinder movements and fuel and boron depletion affects all six capsules largely in the same manner (notice the similar patterns in the inlet $\mathrm{Ne}$ fraction in all capsules in Figure 13). Therefore, an estimated flow rate for Capsule 2 (before TC failures in Capsule 5) was computed using capsule gas flow data from the other five capsules. The data for the period prior to the TC failure were used in a regression analysis which produced the following linear relationship (Equation 1):

$N e f_{2}=0.066 N e f_{1}-0.465 N e f_{3}+1.0598 N e f_{4}+0.314 N e f_{5}+0.298 N e f_{6}$

In Equation (1), $N e f_{\mathrm{i}}$ is Ne flow for Capsule "i." For the regression analysis, the daily average Ne data were filtered to exclude transition power-up and power-down times, outage periods, and periods of time when the test was run on pure helium at the beginning of the experiment. Note that the regression function (Equation 1) does not have an intercept because it is desirable that, if all other capsules are run on pure $\mathrm{He}\left(\mathrm{Nef}_{i}=0\right)$, then Capsule 2 should also run on pure He.

The regression analysis leading to Equation (1) was redone in May of 2011 after Capsule 5 lost its working TCs. The new analysis produced regression equations for both Capsules 2 and 5 using data from the other four capsules.

At any point in time, the actual Ne flow estimates are based on the most recent pattern of Ne flows in the other capsules. For Capsules 2 and 5, the regression equations are used with the daily average flow rates in the other capsules to compute predicted flow rates for the most recent day, and for the previous day. The estimated flow rate for a capsule suggested for the next (future) day is the minimum of the previous day's predicted rate, and the rate $\left[2 N e f_{\text {(recent day) }}-N e f_{\text {(previous day) }}\right]$ obtained by projecting the two 


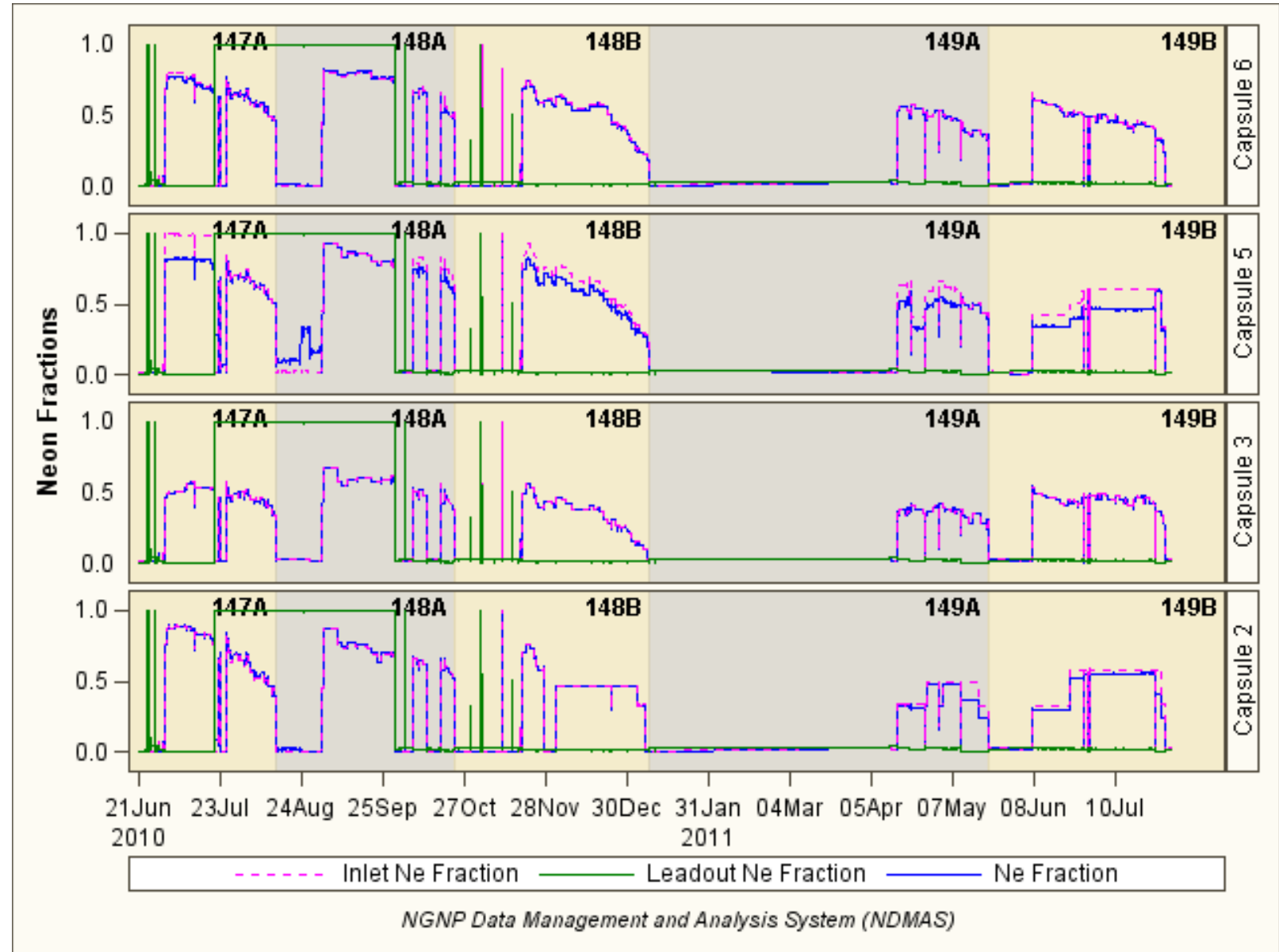

Figure 13. AGR-2 capsule neon fractions (Capsules 1 and 4 are omitted due to Cooperative Research and Development Agreements [CRADA]).

predicted flow rates forward one day. A minimum is used to avoid the possibility of over-estimating the needed flow rate, which would not be conservative.

Figure 15 and Figure 16 show recent daily Capsule 2 and 5 Ne flow estimates. In the graphs, the projected flow rates are in lavender circles. The last circle on each graph extends beyond the period of actual data and is always empty. It is the predicted value. As more data accrue, blue dots are plotted at the values predicted day by day from the regression equation. Comparing the lavender circles with the blue points shows how the projected (suggested) values compare with the actual daily regression equationbased predictions using the Ne flows in the other capsules.

Currently, the estimates are provided to NGNP experiment management personnel after weekly data updates. The Reactor Data Acquisition System (RDAS) has provided ATR data to NDMAS on an automatic basis, but this feature is not currently operational. The Capsule Distributed Control System (CDCS) is planned to collect experiment-specific data such as temperatures and gas flow rates, but it also is not yet operational. When these two systems are fully functioning, AGR experiment data will be added to NDMAS on at least a daily basis and the estimate will be supplied daily.

The thermal simulation model can be used to confirm that the estimated Ne flow rates provide the desired temperature and possibly to update the regression coefficients as needed. 


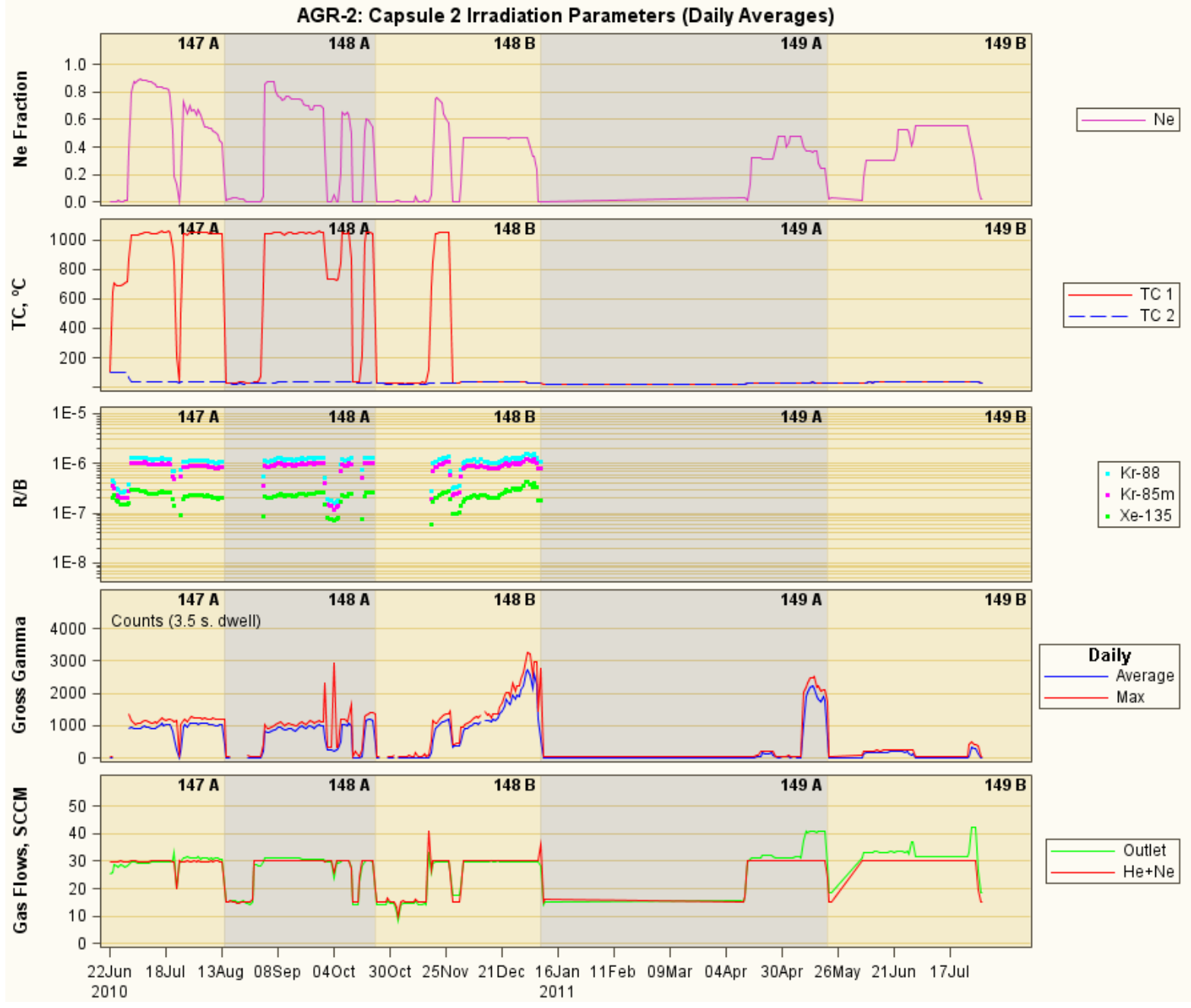

Figure 14. Graphical summary for AGR-2 Capsule 2.

Capsule 2: Neon Flow (Daily Averages) for Current Cycle -- 149 B

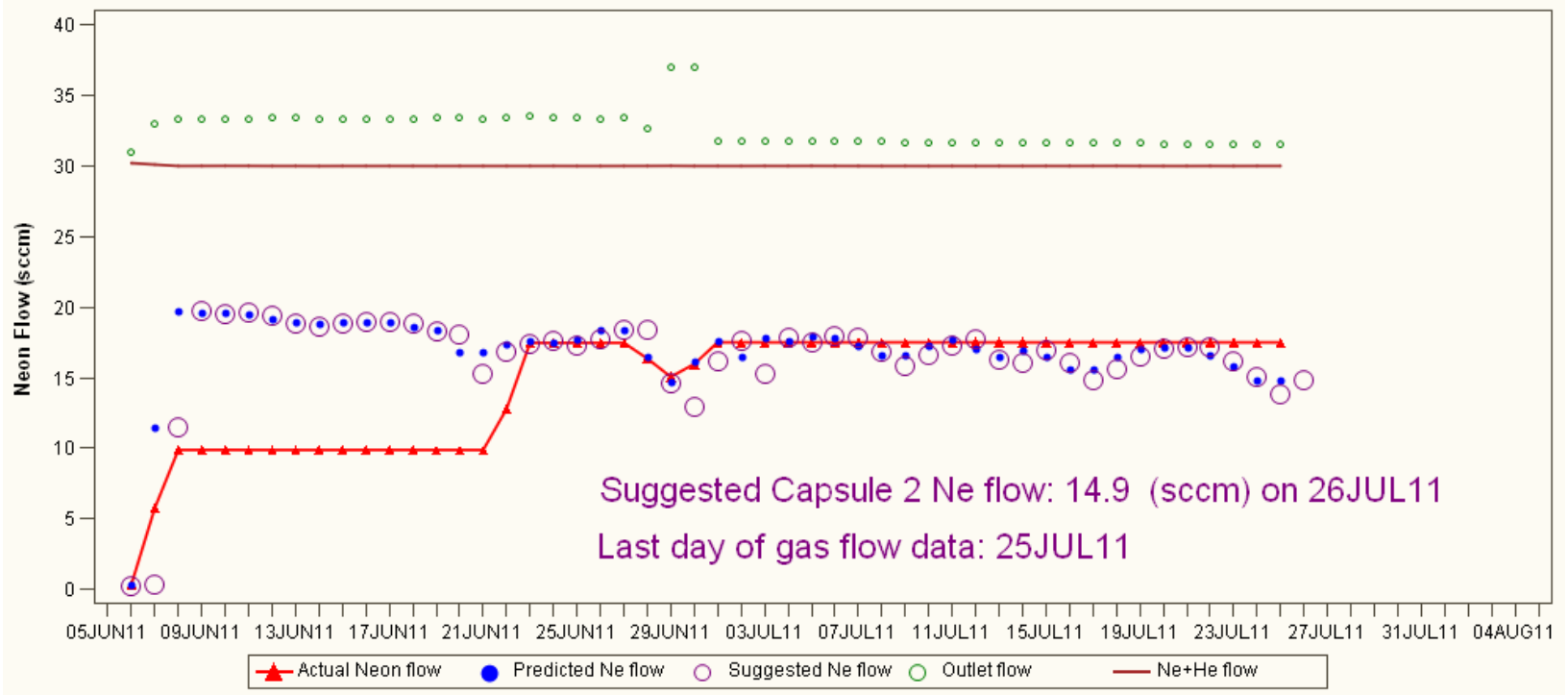

Figure 15. Suggested neon flows for AGR-2 Capsule 2. 


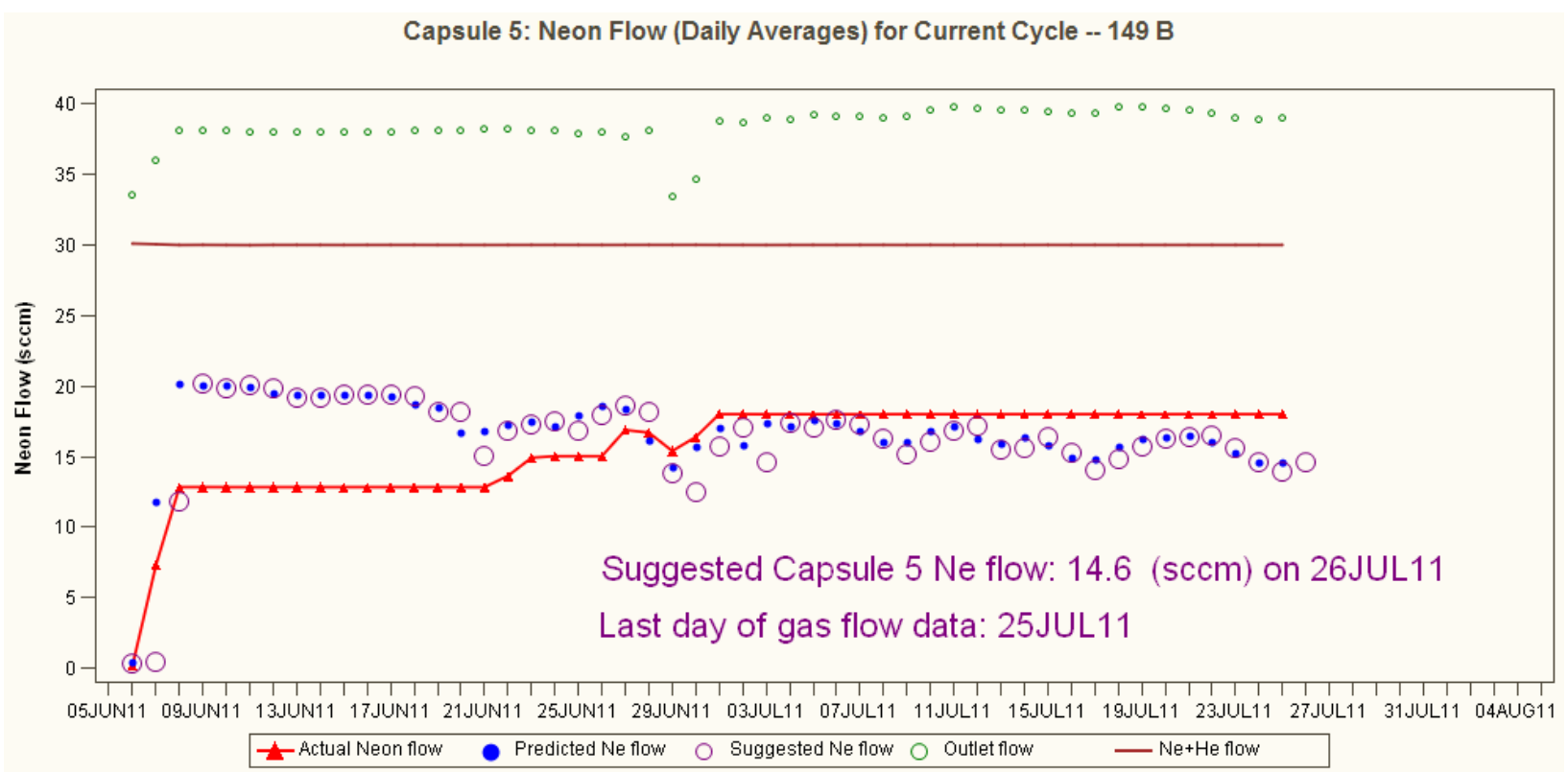

Figure 16. Suggested neon flows for AGR-2 Capsule 5.

\subsection{Studying the Effect of Leakage}

The process just described for estimating Ne flows when TC outputs are lacking does not consider the possibility of leakage in the control gas flow for each AGR-2 capsule. With no leakage, the fraction of $\mathrm{Ne}$ in the capsule gas is simply the $\mathrm{Ne}$ flow rate divided by the sum of the inlet $\mathrm{Ne}$ and He flow rates. However, measurement of the outlet gas flow rate for several of the capsules shows that the outlet gas flow rate does not always equal the sum of the two inlet flow rates. This situation can be seen in Figure 15 and Figure 16 for Cycle 149B by comparing the upper two plotted lines. The situation can also be seen in Figure 13 when the pink plots differ from the blue plot lines. Since the start of the experiment, leakage has been an issue for Capsule 5. The plot also shows total flow differences in the more recent data for Capsule 2.

When a capsule's outlet flow rate exceeds the sum of its inlet flow rates, leadout gas (which flows in a tube that runs down the length of the test train and both contains and protects the capsule instrumentation) might be leaking into the capsule. Conversely, when a capsule's outlet flow rate is less than the sum of its inlet flow rates, gas from the capsule may have leaked into the leadout gas in a manner that bypassed the capsule outlet. The AGR-2 test train is designed to minimize this second type of leak, since the leadout tube is pressurized to about 1 psig above capsule pressure.

The amount of heat removed as the gas flows through a capsule depends on the actual Ne fraction in a capsule. The situation where leadout gas leaks into a capsule is of interest because Ne leadout gas makes the actual Ne fraction (blue line in Figure 13) higher than the (pink line) estimate based on the capsule's inlet gasses. The opposite is true when the leadout gas is primarily He. Figure 13 shows that the leadout gas has been He for most of the AGR-2 experiment (where the green line, which is the same for all capsules, is near zero). NDMAS provides a tool for visualizing and studying such leakage effects.

\subsection{Integrating Experimental Data}

NDMAS provides an environment for linking related data that comes from different investigations in the course of an experiment. For example, the AGR-1 test has fuel fabrication data (FAB), fuel irradiation data (IRR), and post-irradiation examination data (PIE). These data were collected at different places and 
different times. However, they are measurements that spring from activities on the same experimental units or components, namely, the irradiated compacts. In NDMAS, these data can be linked and studied together. Figure 17, from the AGR-1/Fuel Summary web page, is an example of data linking.

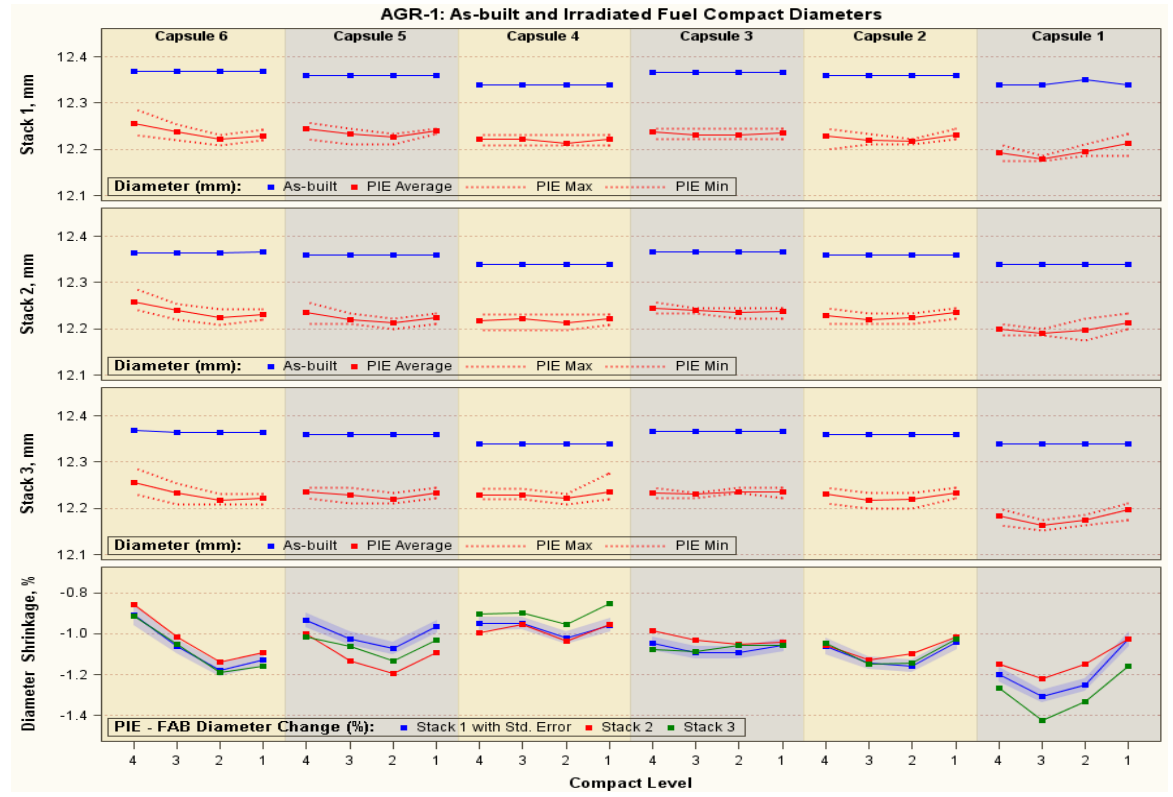

(a) Compact diameters (from fabrication and from post-irradiation examination).

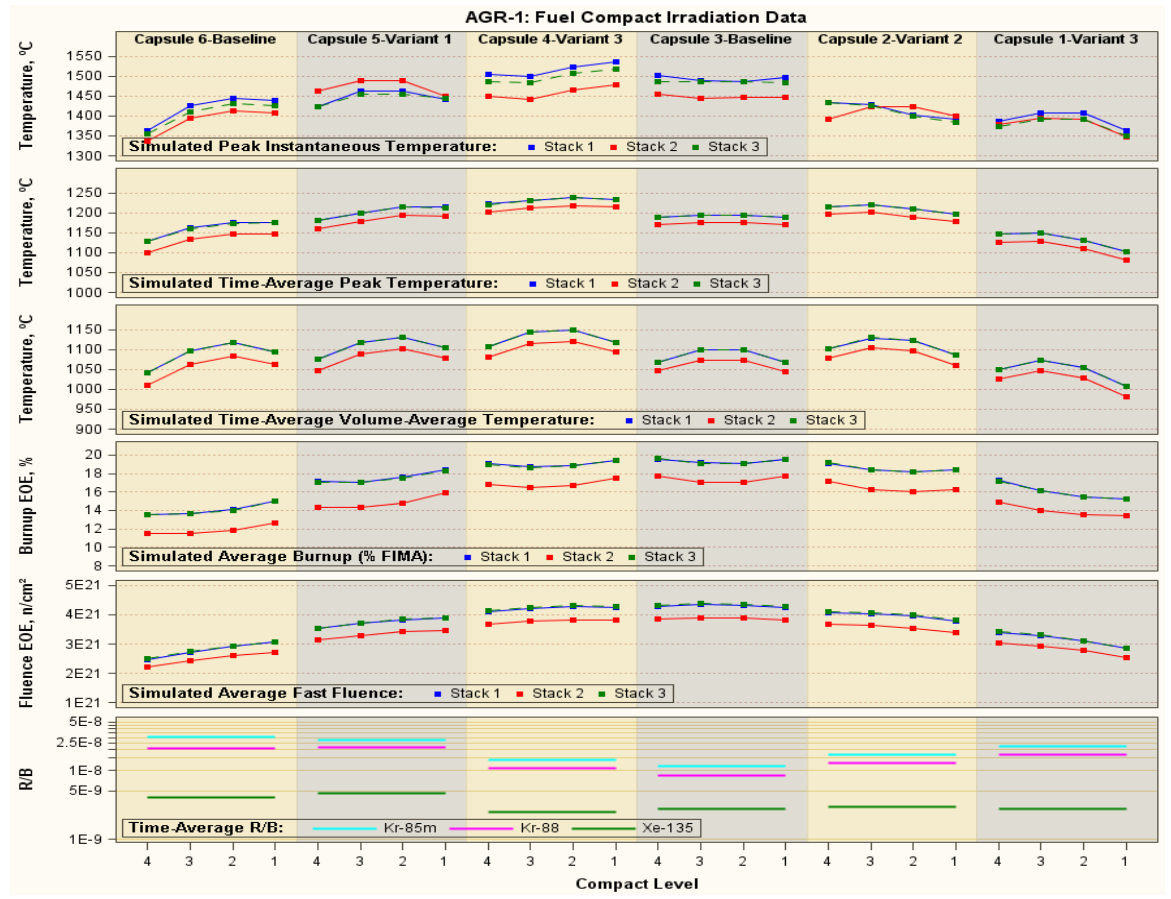

(b) Irradiation parameters plotted according to a compact's position in the AGR-2 test train.

Figure 17. Integrated FAB, IRR, and PIE data for AGR-1 irradiated compacts.

\subsection{TC Monitoring}

The TC monitoring methods discussed in previous editions of this document continue to be used. The three methods are shown in the AGR-2/Analysis/Temperatures web page: control charts, within-capsule 
correlations, and between-capsule correlations. Subsections below provide additional information about these tools.

\subsubsection{Control Chart Monitoring}

The purpose of statistical control charts is to allow simple detection of events that are indicative of actual process change. This simple decision can be difficult when the process characteristic is continuously varying. The control chart provides statistically objective criteria for detecting change. When change is detected and considered valid, its cause should be identified. The AGR and AGC experiment TCs and AGC load cells are subject to a harsh environment and could degrade or fail during the experiment. Control charts provide an objective contribution to the process of deciding when instruments fail or when the possibility of a process change needs to be investigated.

The first step in constructing an ordinary control chart is to identify a quantity that might be fairly constant during the process being monitored. For the VHTR experiments, temperatures and loads may fluctuate but differences in readings from nearby instruments would be expected to be fairly stable. Daily average differences are charted for the TCs and load cells.

The next step to constructing a control chart is to select a baseline period. The average and standard deviation of the daily average differences are estimated. When there are few data points, a large variation is seen in the standard deviation estimates. This variation drops as more data are obtained. A "baseline period" is defined as the period of initial data collection to characterize how the daily average differences behave. When the estimates become stable, the data are considered for the baseline period. The data in that period also need to be fully representative of the process, since data collected during the baseline period are used to define the expected performance of the monitored data.

The mean of the response value in the baseline period is calculated using all of the observations. This mean is used to draw the center line of the control chart. The estimated standard deviation of the observations is calculated and used to draw the upper and lower control limits at 3 standard deviations above and below the mean. If the time series is normally-distributed, $99.7 \%$ of future points will plot between the upper and lower control limits.

Even if the detailed readings are not normally-distributed, daily averages tend to be so. However, whether they follow a single normal distribution (as described by the control charts) depends on whether from day to day the differences being evaluated have the same mean. Data falling outside the control limits tend to indicate a change in the process, such as possible instrument drift. Since isolated points outside the limits can occur without any process changes, a more specific criterion is useful. For use in monitoring the TCs and load cells, an ad hoc criterion is that $10 \%$ of the values must fall outside the band in order to generate a "possibly out-of-control" flag.

In addition to data falling outside the control limits, patterns of data within the control limits can also indicate a possible change in the process generating the data. Including the "possibly out-of-control" rule, there are three rules used to apply control charts to the AGR and AGC monitoring data. They are listed below.

1. Possibly out-of-control rule:

a. Possibly out of control: $>10 \%$ of the days in the monitoring period have differences lying outside the control limits.

b. Possibly out of control warning: $>30 \%$ of the days in the monitoring period have differences lying outside warning limits, which are defined as the baseline mean value \pm 2 standard deviations. 
2. Possible prolonged bias rule:

a. Possible bias up: $>75 \%$ of the days in the monitoring period have differences greater than the baseline mean value.

b. Possible bias down: $>75 \%$ of the days in the monitoring period have differences less than baseline mean value.

3. Possible time trend rule:

a. Possible strong trend: the correlation between differences and run time is $>0.8$ or $<-0.8$.

b. Possible moderate trend: the correlation between differences and run time is between 0.6 and 0.8 or between -0.6 and -0.8 .

When a control chart generates one of these flags, the data are suspect. The method highlights relative TC performance for review by a Data Review Committee (DRC). Data may be accepted in spite of differences outside the limits if the DRC believes, for example, that constant differences between temperatures over time within a capsule are not to be expected because some other phenomenon, such as a changing gas gap, could account for the observed differences. The decision about whether the data are still valid relies most on professional judgment. If the flagged data are judged valid, and the experiment is still running, a new baseline period is instituted that includes these data.

Figure 18, from web page AGR-2/Analysis/Temperatures, is an example of control chart monitoring.

Capsule 6: Control Chart for Daily Average of TC Differences, and Daily Correlations of TC1, TC2

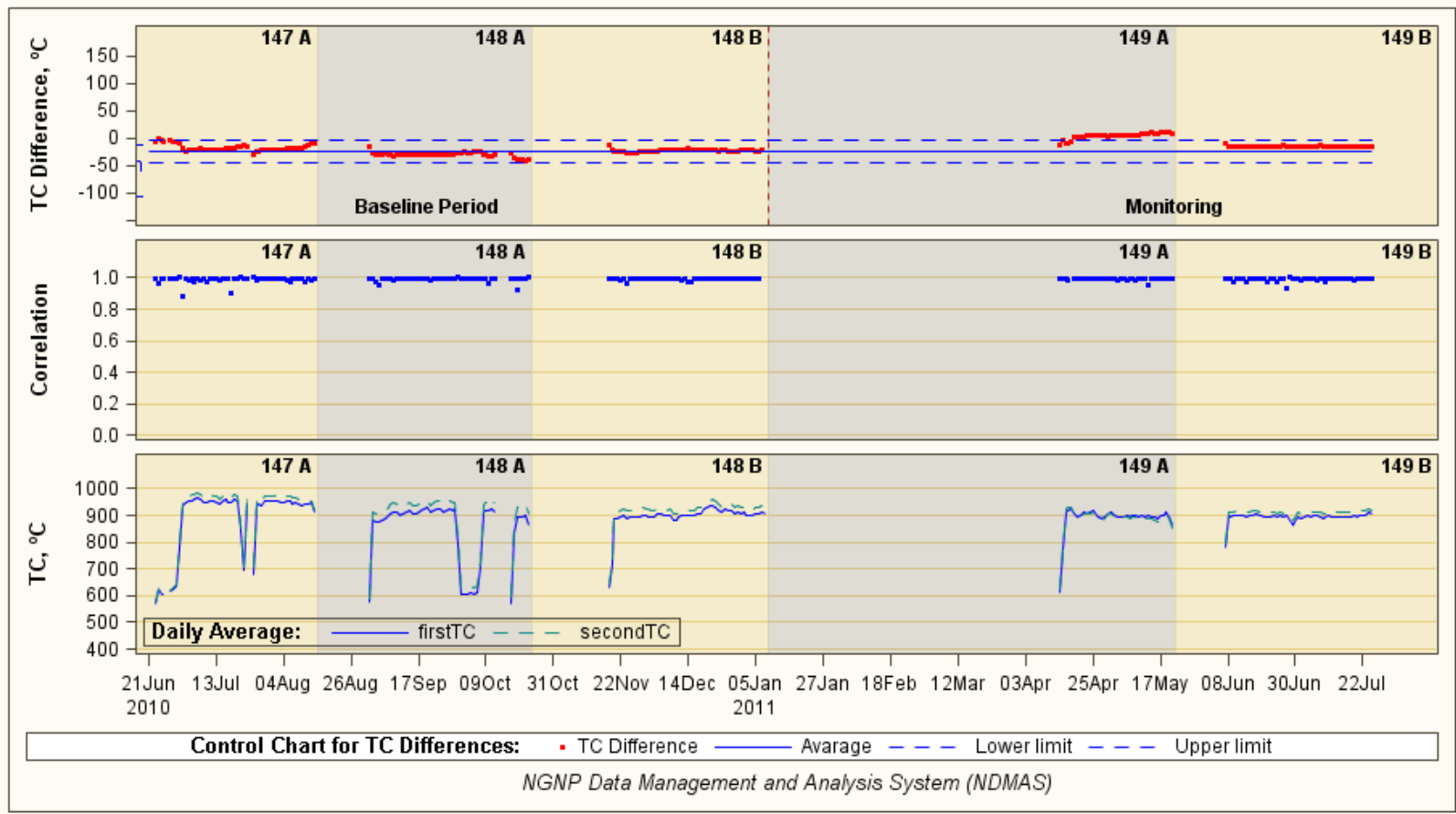

Figure 18. Control chart for TC differences, with correlations and daily average TC readings (TC1 and TC2 in AGR-2 Capsule 6).

\subsubsection{Monitoring Within-Capsule Correlations}

Five-minute TC readings from two TCs provide 288 data pairs each day for a correlation calculation. Readings from two TCs in the same capsule should be highly correlated since they see the same variation in ATR power loading and the same neon fraction in the control gas. A plot of daily correlation 
coefficients using pairs of within-capsule TC readings is expected to show high correlations. When a sequence of such values consistently trails away from 1.0, a potential problem exists with the data. This test is not quite as formal in generating material for the DRC as the control chart method. The middle panel in Figure 18 shows an example of the high correlations.

\subsubsection{Monitoring Between-Capsule Correlations}

For a monitored TC, this tool considers other TCs to identify which one provides measurements most correlated with those of the subject TC. For the AGR experiments, correlated data are expected from the TCs that are closest to the subject TC (i.e., the TCs in the same capsule in the test train). An irregularity has possibly entered a data stream when the location of the most correlated responses to the response being evaluated is no longer nearby. The instrumentation leads enter the test train from the top. A TC junction failure would be indicated by a maximum correlation estimate that is consistently (for several days) in a capsule higher in the test train than the capsule of the subject TC.

Two illustrations of between-capsule correlation monitoring are in Figure 19. The first shows for each TC and day, the capsule with the TC most correlated to the TC being evaluated. This capsule is expected to be the capsule of the TC (so the points are expected to lie on the red lines).

In the second frame of Figure 19, daily correlations coefficients for a pair of control TCs from two different capsules are shown. As expected, the correlation coefficients are more spread out than the within-capsule correlations in the middle panel of Figure 18.

\subsection{Use of the Data to Identify Possible Anomalies}

The VHTR experiments study complex phenomena under conditions that, in many cases, have not been investigated before. The phenomena are modeled using detailed computer codes, and a goal of the research is to adjust the parameters in the codes so that they correctly describe the phenomena. The codes need to be "calibrated" so that they best match the data. On the other hand, the high temperatures and neutron flux may cause TC degradation or changes across a capsule which cannot be measured with the limited number of installed TCs. Many TC failures were seen in the AGR-1 experiment. A challenge in the research is to sort out the differences and decide which data - measured or calculated — is the most accurate.

A strength of NDMAS is that the data sets are in one place, with tools to investigate these issues and delineate where the greatest differences are to be found. For example, in the AGR-1 experiment differences were seen between the "valid" TC measurements and the estimated temperatures at the TC locations that came out of the detailed neutronics and thermal modeling. Daily average temperatures are plotted in Figure 20. Figure 21 shows simulated minus measured TC differences in the top three panels for TC1, TC2, and TC3 in Capsule 6. The simulated and measured temperatures for TC1 depart from one another after 230 EFPD. The blue dot temperature differences in the fourth panel show TC1 simulatedminus-measured values increasing by approximately $70^{\circ} \mathrm{C}$ from 230 EFPD to the end of the experiment. Figure 22 shows that the measured differences between TC1 and TC4 (the purple dots) are higher than the simulated differences (gray dots) by approximately $50^{\circ} \mathrm{C}$ at the beginning, then end up around $20^{\circ} \mathrm{C}$ lower at the end of the experiment. Again, these data show a possible drift of $70^{\circ} \mathrm{C}$. So, although $\mathrm{TC} 1$ in Capsule 6 has not been declared to be failed, it may have experienced a drifting problem. Another possible alternative is that some physical phenomenon occurred, such as a change in the size of the gaps in Capsule 6 where the $\mathrm{Ne} / \mathrm{He}$ gas mixture flows.

The same could be true for TC2 in Capsule 6 in the last few cycles of the AGR-1 experiment. The plots assembled in Figure 23 show departures from a regression model, points falling out of bounds on a control chart, much wider variations in the distributions of daily within-capsule correlations between TC2 
Capsule 6: Capsule Containing TC most Highly Correlated with Subject TC (Panel Label)

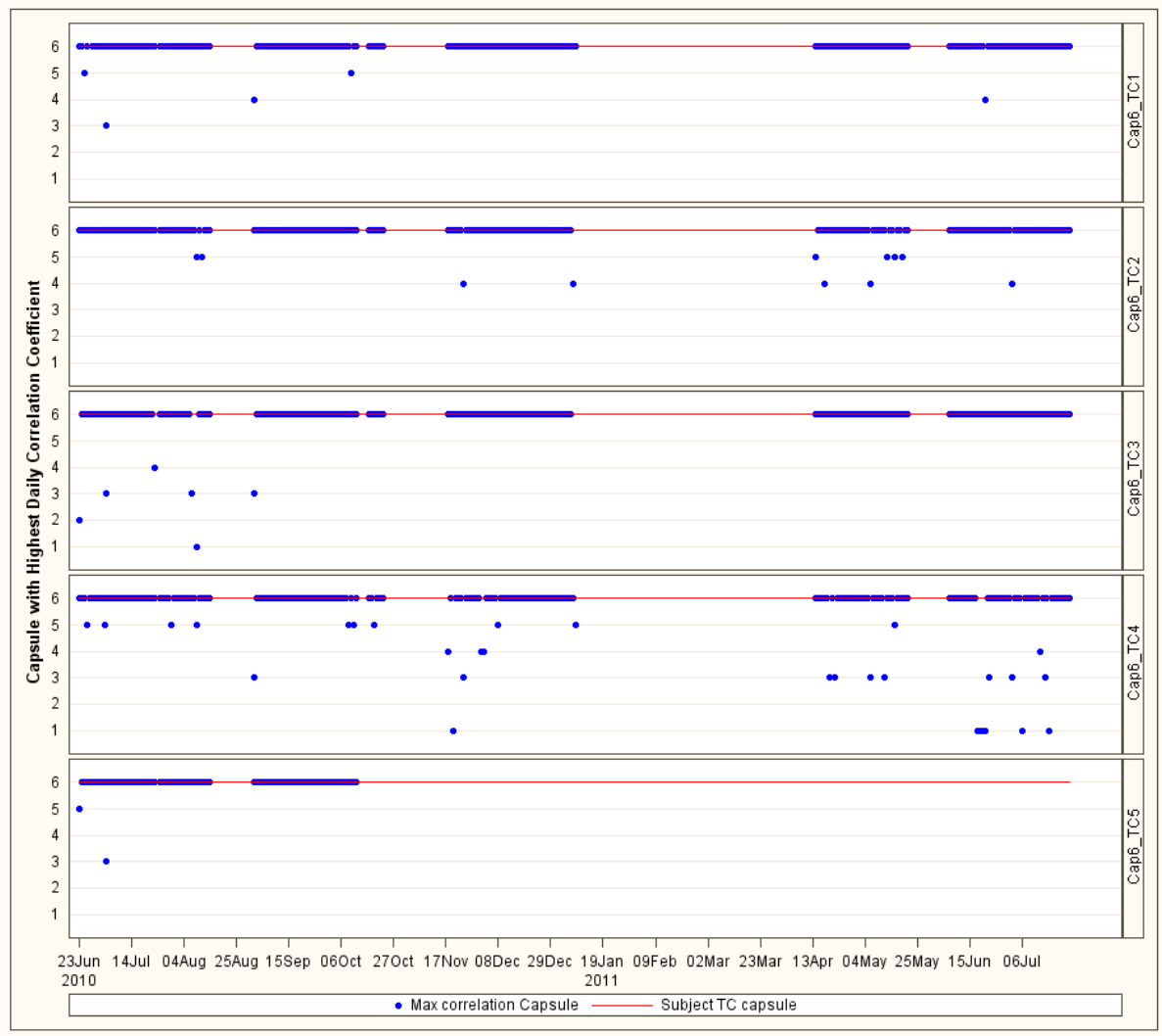

(a). Capsule with most highly-correlated TC, for each TC in AGR-2 Capsule 6.

Daily Between-Capsule Correlation Coefficients of Control TCs: Cap6_TC1, Cap5_TC1

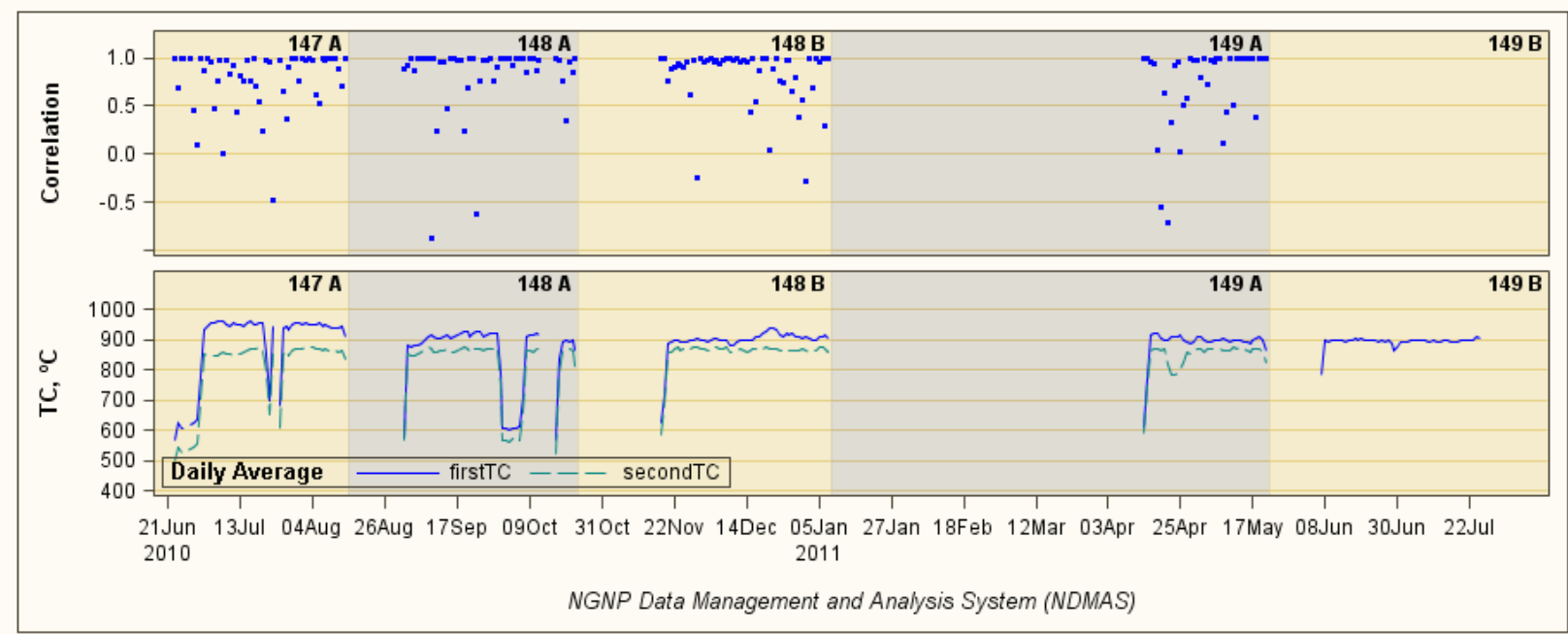

(b). Between-capsule correlations for control TCs in two different capsules (5 and 6) from AGR-2.

Figure 19. Monitoring between-capsule correlations for TCs in AGR-2 Capsule 6. 


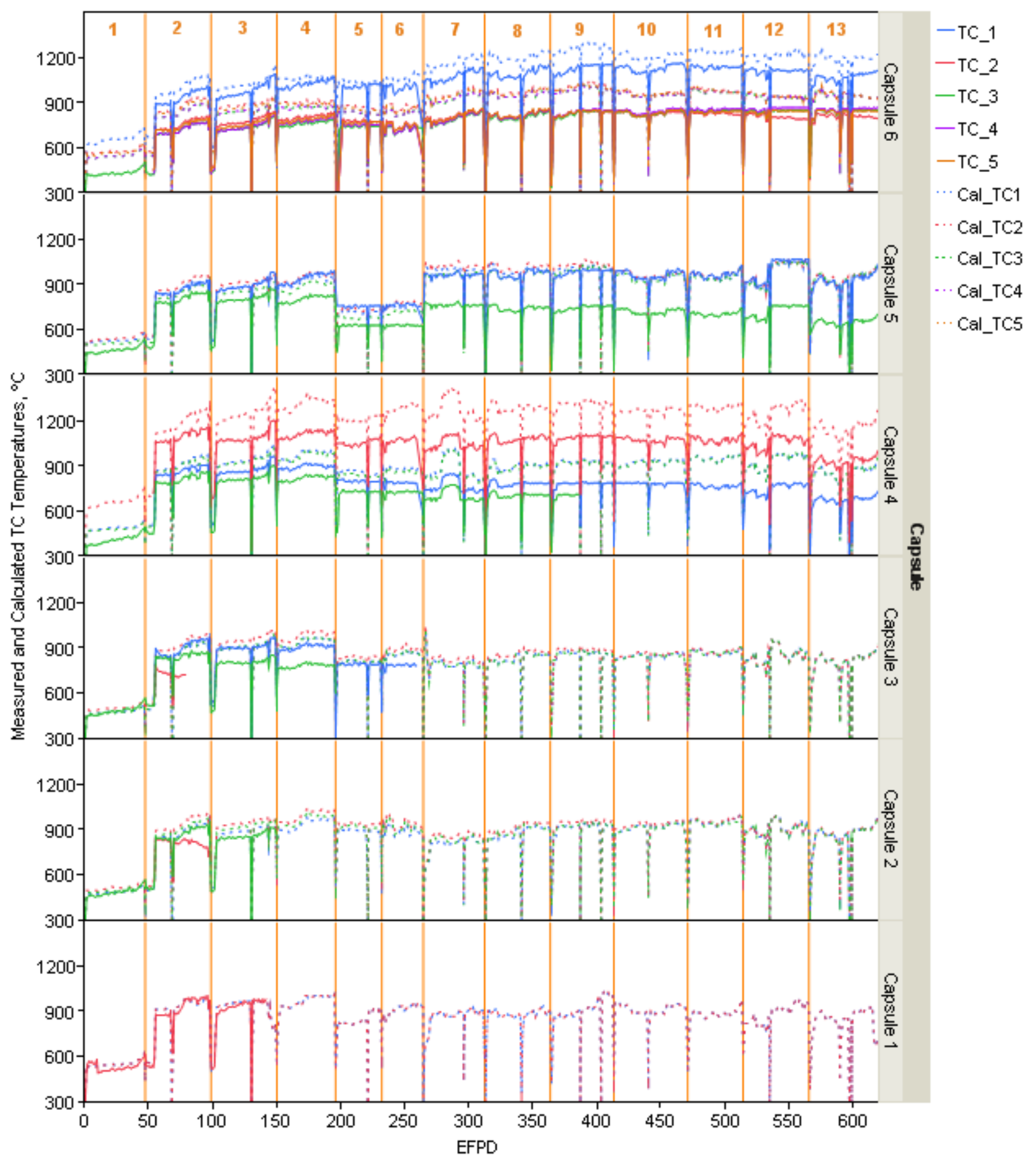

Figure 20. Measured and simulated AGR-1 TC temperatures. 


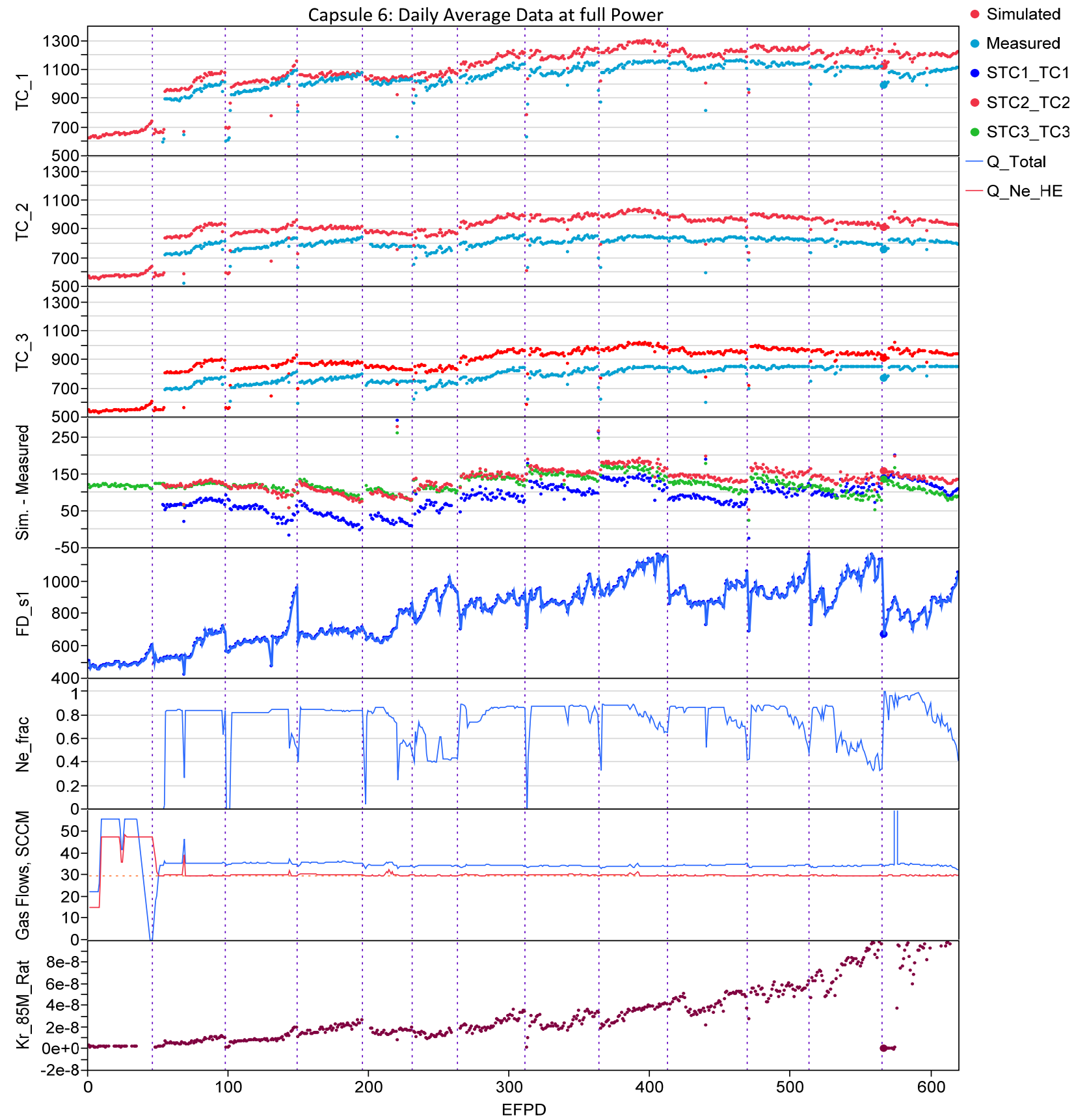

Figure 21. Daily average data for AGR-1 Capsule 6 at full power. 


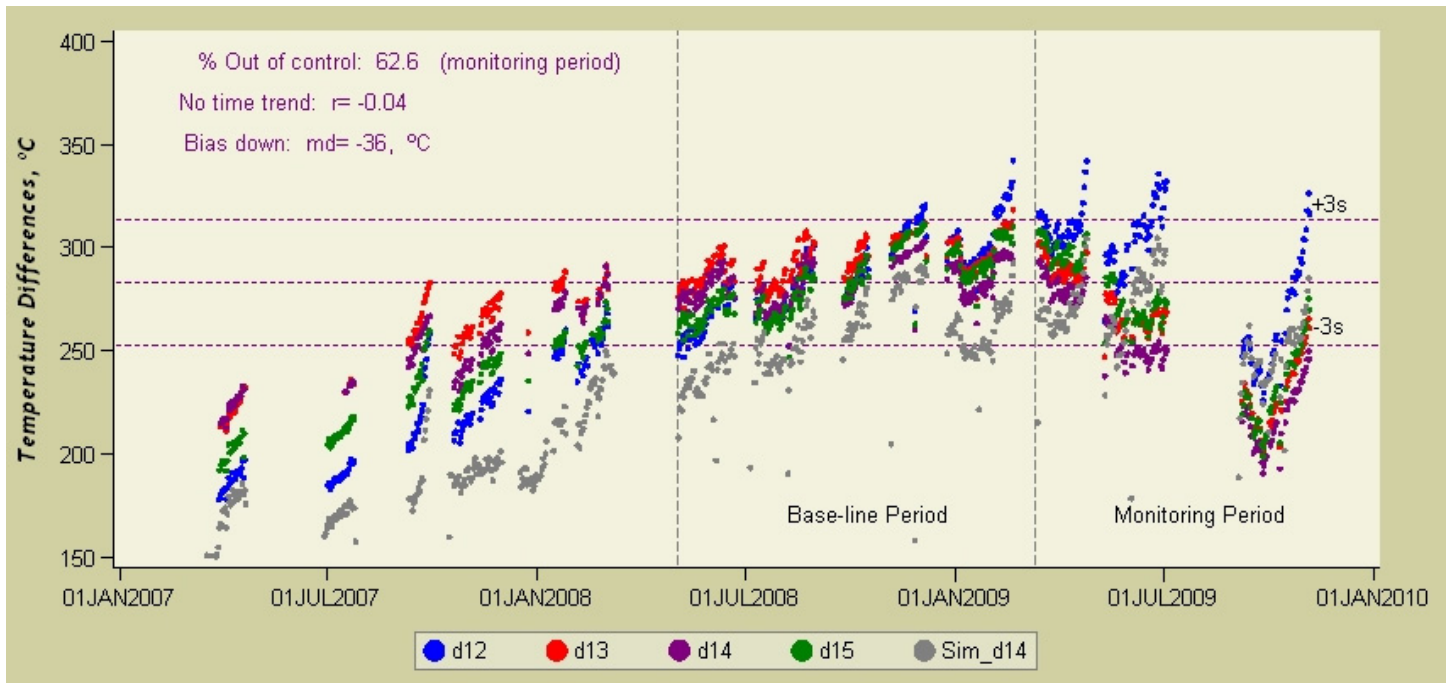

Figure 22. AGR-1 control chart for TC differences for TC1 and TC4 in Capsule 6.

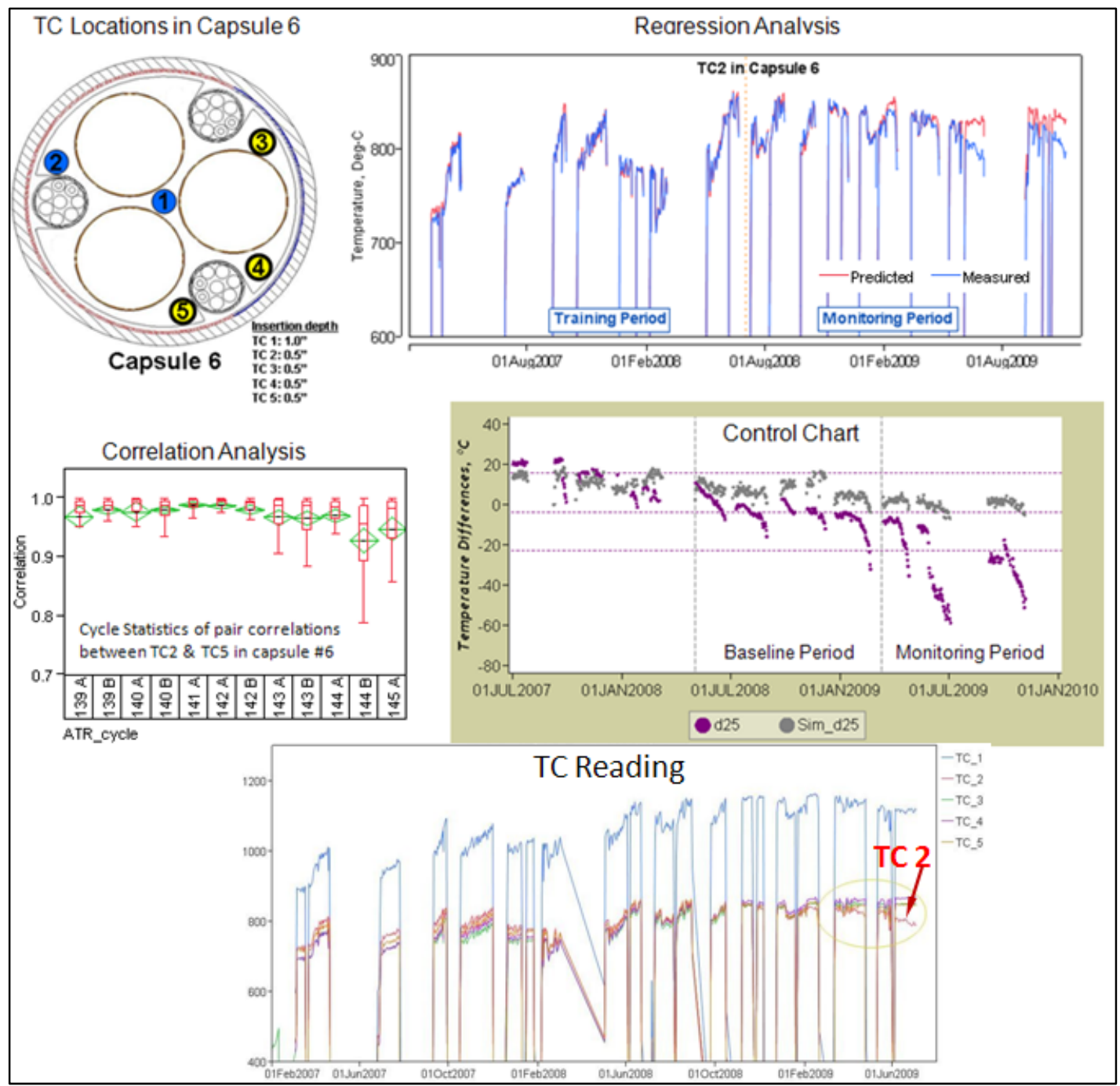

Figure 23. Compendium of plots on possible drift of TC2 in Capsule 6 near end of AGR-1 irradiation. 
and TC5 near the end of the experiment, and a dropping off of the TC readings in a plot of the readings themselves. All of these deviations occur in the last two cycles of the irradiation.

Many other examples of peculiarities are possible. In the panel showing simulated and measured temperature differences in Figure 21, there is a repeating pattern in the data within most of the ATR cycles. Also, the bottom panel shows an increase in the $\mathrm{Kr}-85 \mathrm{~m} \mathrm{R} / \mathrm{B}$ ratio in the last cycle of the irradiation. The NDMAS provides the capability to bring together the different sources of data and investigate trends and patterns.

\subsection{Use of Regression Models for Sensitivity Studies}

When an empirical model has been fit to data, relationships among the variables in the model can be studied in a graphical interface that is part of the SAS software product, JMP. The JMP documentation calls this capability "prediction profiling." An analyst can use this tool to specify desired levels for one or more variables in the model and then observe how the other variables must change in order to achieve a desirable outcome. The tool facilitates intuitive sensitivity analyses of the relationships among the variables that are represented in the fitted model.

The following example illustrates the use of prediction profiling. The example uses EFPD, the neon fraction, and the fuel fission power and graphite fission density values that come out of the physics modeling of the experiment. The quantities that change most during the experiment are the fuel fission power and neon fraction. The EFPD is fixed at some particular time of interest, and the graphite fission density changes fairly slowly. (Note that the physics model-based estimates are not available during the experiment, so these relationships are studied after completion of the part of the experiment that generates the data). In the example, a goal is to maintain the average fuel temperature at, say, a target value of $1050^{\circ} \mathrm{C}$, by manipulating the neon fraction as the fuel fission power changes.

Without using JMP, an analyst could study how the neon fraction would need to change in response to fuel fission power changes using the following process:

- Fit a regression model to the physics-modeled average fuel temperature ("SFT_AVE") using the EFPD, modeled fuel fission power ("FD_W"), modeled graphite fission density ("GR_CD”), and measured neon fraction ("Ne_Frac"):

$$
S F T_{-} A V E=a_{0}+a_{1} E F P D+a_{2} F D_{-} W+a_{3} G R_{-} C D+a_{4} N e_{-} \text {Frac }
$$

The term, EFPD, turns out not to be statistically significant in this regression model but it is retained because it is significant in regression models with these independent variables for both measured and physics-modeled TC temperatures. The EFPD term provides an overall trend for changes that span the experiment irradiation time.

- Estimate the five coefficients.

- Solve the regression equation for Ne_Frac:

$$
N e_{-} F r a c=\left[S F T T_{-} A V E-\left(a_{0}+a_{1} E F P D+a_{2} F D_{-} W+a_{3} G R R_{-} C D\right)\right] / a_{4}
$$

- Substitute nominal values for EFPD and GR_CD, and set SFT_AVE at its target value, $1050^{\circ} \mathrm{C}$.

- Substitute a series of values for FD_W and observe how the neon fraction changes as to maintain SFT_AVE at the target level.

The SAS JMP prediction profiling tool facilitates this process by displaying a matrix of little dynamic graphs, shown in each of the panels in Figure 24. The matrix has a row for each response variable (in the 


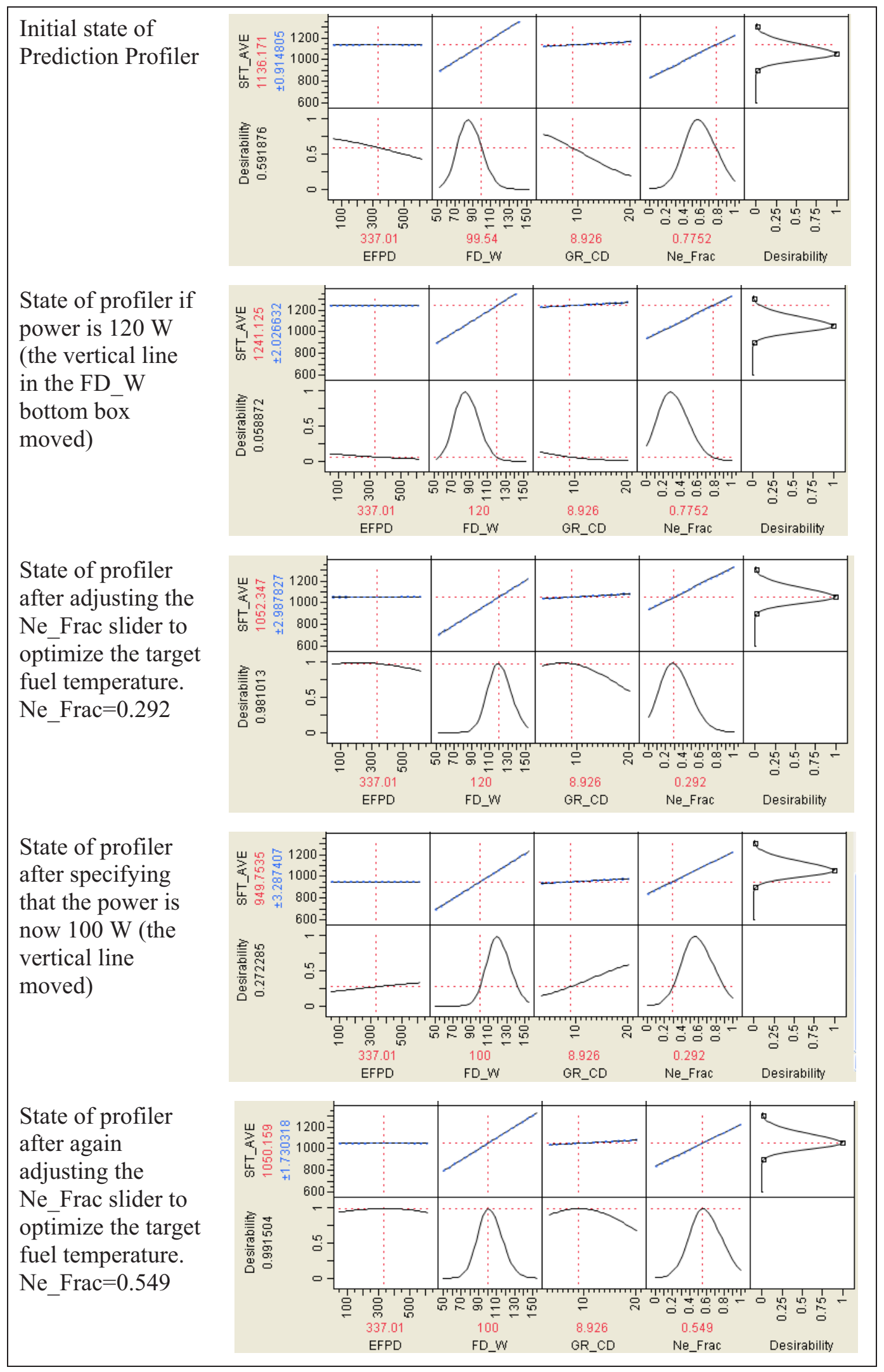

Figure 24. JMP prediction profiler for predicted fuel temperature in AGR-1 Capsule 6. 
current example, one such row). The bottom row has columns for each input variable and for a quantity called "desirability."The profile user first selects a "desirability function" for the quantity of interest (average fuel temperature) by specifying a target value along with upper and lower bounds and associated tail probabilities. The regression generates the rest of the little figures. The blue curves in the top row show the sensitivities of the output fuel temperature to the four input parameters. Each blue curve is a plot of output fuel temperature as a function of a particular input variable, with the other variables held constant at specified values. These specified input values are plotted in the vertical red lines in the display, which can be dragged to select other values.

After picking nominal values for EFPD and GR_CD, one can observe the effect of changes in fuel fission power on the $\mathrm{Ne}$ fraction needed to achieve the target fuel temperature by inputting fission power values using the red dotted line slider in the second box on the bottom row. For each fission power value, an adjustment to the slider in the "Ne_Frac" box (dragging it with the mouse) allows the system to find the $\mathrm{Ne}$ fraction setting that gives the desired fuel temperature. Figure 24 shows the state of the profiler and how it responds as the user moves through this process. At each stage, the display retains the regression relationship shown in Figure 25.

Models such as the example can also be studied using subsets of the data. For example, if performance during ATR Cycle 143B is under study, the input data could be restricted to the three or four cycles preceding Cycle 143B. After a regression model is developed that fits the data, the profiler can be used to study the relationships.

The profiler can be used to study the relationships between variables for virtually any regression model.

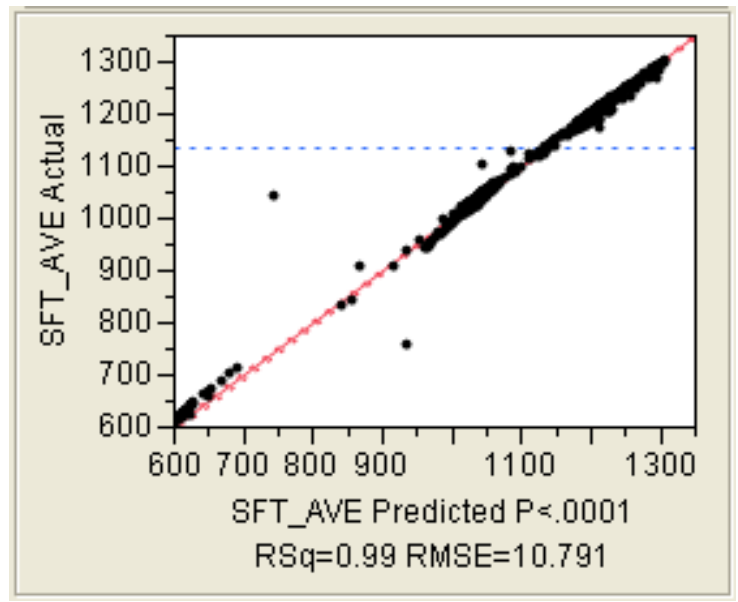

Equation:

Simulated Avg. Fuel Temp

$(\mathrm{SFT}$ AVE $)=$

298.631864724172

$+0.0029132001312^{*} \mathrm{EFPD}$

$+5.12969694548567^{*} \mathrm{FD} W$

$+2.58695179808901{ }^{*} \mathrm{GR} \_\mathrm{CD}$

$+390.681673009338 *$ Ne_Frac

Figure 25. Regression model behind prediction profiler.

\subsection{Potential Use of Regression Models for Experiment Control}

The fuel temperature in the AGR irradiation experiments is controlled by setting a target temperature for a capsule's control TC. Given such a value, the control system automatically adjusts the neon fraction in the control gas to either increase the control TC's reading to reach its target, or to lower the temperature reading to reach the target.

An issue is the selection of an appropriate target value for the control TC that will produce desired fuel temperatures. When an experiment has progressed so that two or three cycles of simulated fuel and TC temperature data are available, one can evaluate the differences and factor that information into the process of determining the control TC target. Cycle-average differences in readings from TC1 and the 
simulated fuel temperature in Capsule 6 in AGR-1 varied from approximately $26^{\circ} \mathrm{C}$ in Cycle $139 \mathrm{~A}$ to approximately $134^{\circ} \mathrm{C}$ in Cycle $143 \mathrm{~A}$. Characterizing these differences and making predictions from the model for future cycles can assist in experiment control. For example, if the model showed that the expected difference (fuel temperature minus the measured control $\mathrm{TC}$ temperature reading) is $100^{\circ} \mathrm{C}$, then the control TC target temperature would be set at the target fuel temperature minus $100^{\circ} \mathrm{C}$. Even if the control TC were drifting, the statistical data modeling could account for the drift in identifying the new setting. This evaluation would be performed after each reactor cycle. 


\section{ONGOING AND PROPOSED FUTURE DATA ANALYSES AND WEB DISPLAYS}

Ongoing and future data analysis and web display capabilities can be viewed from two perspectives: the applications that may be developed and the new capabilities that come from enhancements in the set of tools available to support those applications.

\subsection{Applications}

The primary ongoing modeling effort for NDMAS is to add displays to the website that will show each new data stream as it is identified and added to the database. The AGR-2 and AGC-2 experiments will continue to generate data. More high-temperature materials experiments will be performed.

Another priority for ongoing work is to look into models and relationships that might exist based on requests received from the community of VHTR researchers.

\subsection{Enhanced Capabilities}

One capability that will be enhanced during the next year is the acceleration of transfer of data updates to the NDMAS web portal. The data there will be more current as the data acquisition systems from ATR improve and the reports that generate plots from Enterprise Guide are updated automatically. Also, as funding permits, the use of the Phoenix Modeling Center (PMC) software may bring some enhancements to the existing work processes. The PMC is a tool to enhance workflow automation.

Another possible enhanced capability is the use of JMP Version 9, which includes the ability to create Flash videos. Graphs such as the Profiler (Figure 24) have sliders. The user can observe how one quantity changes as the slider moves another quantity. Such displays can be recorded and used in the website. 


\section{SUMMARY AND CONCLUSIONS}

NDMAS provides many powerful data analysis and web display capabilities. Users accessing the INL NDMAS web portal can study relationships between key outcomes in the experiment and various experimental conditions using such features as:

- Scatter plots, line plots, and bar charts or combinations of these

- Histograms and box plots that show distributions for the sample data

- Panel plots that break the data into subsets such as data from different capsules, and show each in successive panels having a common time or other axis

- Matrix plots that show all the pair-wise relationships within a set of variables

- ActiveX graphs that allow the user to manipulate many of the features of the graph to enhance understanding

- Tool tips in graphs that show the data behind plotted values of interest as the user rests the mouse over apparent outliers or other graph features

- Reports that allow users to perform their own variable selection, sorting, filtering, and downloading

- Plots and data displays based on hierarchical cubes, allowing users to drill down and display more detailed levels in the data

- Stored processes that, for example, allow users to view gross gamma counts for the time frame and capsule that they select.

This report describes these website features as they are implemented as of September 2011. Because the website is updated frequently, the content that can be studied using tools such as these will continue to evolve.

Even more data analysis tools are available for developers creating content for the website. All of the statistical power of SAS, Inc.'s SAS/STAT statistical software is available, in addition to the SAS/QC software for control charts and complete access to several graphing products for data visualization. The SAS/STAT regression procedures, in particular, provide modeling frameworks that can be tailored to the nature of the data being analyzed. In the process of fitting a parametric model to data, the researcher makes assumptions about how the data set was generated, whether certain quantities are independent, etc. The SAS procedures allow many of these assumptions to be relaxed. Nonlinear regression is supported, so that functional relationships established from physical models can be accommodated. Different distributional forms can be considered, as well as a variety of variance structures. Ultimately, empirical data modeling is about separating process variation that can be understood and to some extent controlled from the random "noise" that is always a part of observed data. The flexibility and power of the SAS system for data analysis optimizes the possibility of deriving useful information from the data modeling efforts.

This report has provided examples of current applications of some of these technologies. Many of the applications deal with describing temperatures during the AGR-1 irradiation experiment and applying that information to the AGR-2 irradiation data currently coming into the system.

Since all VHTR researchers can request the NDMAS team to investigate and display particular relationships between variables on the web, or download data and investigate these relationships themselves, the data analysis and web delivery capabilities of NDMAS are virtually unlimited. 


\section{REFERENCES}

Abbott, M. L., L. C. Hull, B. T. Pham, and M. A. Plummer, 2010, AGR-1 Data Qualification Report, INL/EXT-10-17943, March 2010.

Ambrosek, R. G., 2005, “Thermal Analyses for Design of AGR-1,” EDF-5138, Idaho National Laboratory, October 3, 2005.

ASME, 2000, Quality Assurance Requirements for Nuclear Facility Applications, Nuclear Quality Assurance (NQA-1), ASME International, New York, NY.

Chang, G. S. and M. A. Lillo, 2007, "Confirmatory Neutronics Analysis of the AGR-1 Experiment Irradiated in ATR 8-10 Position," EDF-7120, Rev 1, Idaho National Laboratory.

Hawkes, G., 2010, “AGR-1 Daily As-run Thermal Analyses,” ECAR-968, Idaho National Laboratory, May 20, 2010.

Hull, L. C., 2010, AGC-1 Irradiation Data Qualification Interim Report: Data from ATR Cycles 145 A, 145 B, $146 A$ and 146 B, INL/EXT-10-19630, September 2010.

INL, 2011, Very High Temperature Reactor Program Data Management and Analysis Plan, PLN-2709, Rev. 3, Idaho National Laboratory.

INL, 2011, VHTR Technology Development Office Quality Assurance Program Plan, PLN-2690, Rev. 8 , Idaho National Laboratory.

Krusch, S., 2009, General Software Management Plan for the VHTR TDO, PLN-2247, Rev 0, Idaho National Laboratory.

Lillo, M. A. and G. S. Chang, 2007, Neutronics Projection Analysis to Support the End of Irradiation Determination for the AGR-1 Experiment, ECAR-515, Idaho National Laboratory.

SAS Institute, Inc., SAS ${ }^{9} 9.2$ Intelligence Platform Web Application Administration Guide, 4th Ed., 2010.

Sterbentz, J.W., 2010, JMOCUP As-Run Daily Depletion Calculations for the AGR-1 Experiment in ATR B-10 Position, ECAR-958, Rev 0, May 14, 2010.

Wright, R. N., 2010, Next Generation Nuclear Plant Reactor Pressure Vessel Materials Research and Development Plan, Idaho National Laboratory, PLN-2803, Rev. 1, July 14, 2010.

Wright, R. N., 2010, Next Generation Nuclear Plant Intermediate Heat Exchanger Materials Research and Development Plan, Idaho National Laboratory, PLN-2804, Rev. 1, September 23, 2010. 


\section{Appendix A}

\section{VHTR Experiments and Associated Data Streams}




\section{Appendix A}

\section{VHTR Experiments and Associated Data Streams}

Data streams currently being processed or developed for very high temperature reactor (VHTR) research are briefly described below. They are organized according to the data collection projects currently described in the Very High Temperature Reactor Program Data Management and Analysis System (NDMAS) Program Plan (PLN-2709ª).

\section{A-1. Fuel Development and Qualification Project}

A series of Advanced Gas Reactor (AGR) experiments are planned to study the performance of possible fuels for the VHTR. The two designs under consideration for the VHTR are a prismatic block design with low-enriched uranium oxycarbide (UCO) fuel particles and a pebble bed design with lowenriched uranium dioxide $\left(\mathrm{UO}_{2}\right)$ fuel particles. Within these two major groupings, a variety of fabrication methods and coatings are possible for the fuel. The experiments are designed to identify fuel that can, among other things, endure the operating conditions of the VHTR, including high temperatures, without leaking or deforming. The experiments will provide data to justify Nuclear Regulatory Commission (NRC) licensing of the selected fuel design.

In the AGR-1 experiment, approximately 300,000 fuel particles were fabricated and loaded into compacts (approximately 4150 per compact), which were installed in capsules. The capsules were loaded in a test train that was installed in the Advanced Test Reactor (ATR) at Idaho National Laboratory (INL). There were 12 compacts per capsule and six capsules total. In the ATR, the capsules were irradiated over a period of nearly 36 months, at temperatures generally exceeding $1000^{\circ} \mathrm{C}$. Conditions in the experiment were recorded frequently (e.g., every 5 minutes) until the last irradiation in November of 2009. The test train was transferred from ATR in March, 2010, to the Hot Fuel Examination Facility (HFEF) at the Materials and Fuels Complex (MFC) where post-irradiation examination (PIE) to provide more information about the fuel performance is underway.

The second experiment in the AGR series is currently being irradiated in the ATR reactor. AGR-2 has a configuration similar to AGR-1, and is testing additional fuel variants.

Additional experiments will test other fuels, fuels at higher temperatures, and fuels sized at a scale comparable to the fuel planned for the demonstration VHTR.

The fuel experiments give rise to such data sets as:

- Fuel fabrication data (see Table A-1)

- Irradiation data (see Table A-2)

- Fission product monitoring system data (see Table A-3)

- ATR reactor operations data (see Table A-4)

- Neutronics and temperature analysis data (see Table A-5)

- PIE data (see Table A-6).

a. INL, 2011, "VHTR Program Data Management and Analysis Plan,” PLN-2709, Rev. 3, Next Generation Nuclear Plant Project, July 2011. 
The tables below list attributes measured in the experiment by component or experimental unit. Components are structured in a hierarchical fashion in the database so that the data can be associated with the level of entity that is being monitored.

Table A-1. Fuel fabrication and compact data parameters.

\begin{tabular}{|c|c|}
\hline Component & Response Variables and Attributes \\
\hline Kernel batch, fabricated fuel kernels & Envelope density, diameter, and sphericity \\
\hline Kernel composite & $\begin{array}{l}\text { Enrichment, composition, impurity levels, diameter, density, } \\
\text { sphericity }\end{array}$ \\
\hline $\begin{array}{l}\text { Surrogate particle batch, kernels coated } \\
\text { with buffer and IPyC layers }\end{array}$ & Buffer and IPyC layer densities \\
\hline Fully coated particle batches & Layer thicknesses, missing OPyC layer defect fraction \\
\hline $\begin{array}{l}\text { Coated particle composite, kernels coated } \\
\text { with buffer, IPyC, SiC, and OPyC layers }\end{array}$ & $\begin{array}{l}\text { Layer thickness, density, defect fraction, aspect ratio, } \\
\text { pyrocarbon layer anisotropies, } \mathrm{SiC} \text { layer microstructure }\end{array}$ \\
\hline $\begin{array}{l}\text { Individual compact, particles } \\
\text { encapsulated into fuel compact }\end{array}$ & Diameter, length \\
\hline Compact composite $^{\mathrm{a}}$ & Purity, strength, U loading, defects \\
\hline Particle and compact & $\begin{array}{l}\text { Manufacturing conditions - gas ratios during coating, } \\
\text { temperatures during coating, compact molding pressure, } \\
\text { compact carbonization, and heat treatment conditions }\end{array}$ \\
\hline Compact & Irradiation position-stack, capsule \\
\hline
\end{tabular}

a. A compact composite is a sample of compacts that is destructively tested for application to all compacts.

Table A-2. Reactor irradiation data parameters and attributes for the AGR (fuel) experiments.

Component Response Variables and Attributes

Capsule $\quad$ Temperature from thermocouples, helium, neon, and total gas flow

Capsule and leadout Gas pressure and moisture content

Table A-3. Fission product monitoring data parameters and attributes.

\begin{tabular}{ll}
\hline \multicolumn{1}{c}{ Component } & \multicolumn{1}{c}{ Response Variables and Attributes } \\
\hline Capsule & Fission product concentrations in sweep gas \\
& Calculated release to birth ratios of fission products \\
& Gross gamma monitoring data \\
\hline
\end{tabular}

Table A-4. ATR operating conditions data parameters and attributes.

\begin{tabular}{ll}
\hline \multicolumn{1}{c}{ Component } & \multicolumn{1}{c}{ Response Variables and Attributes } \\
\hline Reactor & ATR lobe power \\
& ATR shim cylinder position \\
& ATR core inlet temperature \\
\hline
\end{tabular}


Table A-5. NGNP neutronics and temperature analysis parameters and attributes.

Component

Response Variables and Attributes

Fuel compact or Neutronics analysis data, calculated fluence

graphite specimen Thermal analysis data, prediction of specimen temperatures

Table A-6. Fuel PIE data parameters and types (preliminary data).

\begin{tabular}{|c|c|}
\hline Component & Response Variables and Attributes \\
\hline Test train & $\begin{array}{l}\text { Pictures, observation notes, gamma scans, metrology, graphite holder } \\
\text { dimensions }\end{array}$ \\
\hline $\begin{array}{l}\text { Graphite holder, } \\
\text { capsule components }\end{array}$ & Detailed gamma scan and radioisotope inventories \\
\hline $\begin{array}{l}\text { Flux wire, melt wire, } \\
\text { capsule liner }\end{array}$ & $\begin{array}{l}\text { Estimated maximum temperature, neutron flux data, and emissivity values used } \\
\text { in modeling }\end{array}$ \\
\hline Thermocouples & $\begin{array}{l}\text { Metallographic images and other data to examine chemical interactions and } \\
\text { microstructure }\end{array}$ \\
\hline \multirow[t]{2}{*}{ Fuel compact } & $\begin{array}{l}\text { Physical dimensions, detailed gamma scan, radioisotope inventories, selected } \\
\text { photos to support fuel qualification, fuel particle failure by leach-burn-leach, } \\
\text { post-irradiation safety testing }\end{array}$ \\
\hline & Photos, notes, irradiation \\
\hline Fuel particles & $\begin{array}{l}\text { Radioisotope inventory, metallography, inspection of layer integrity, photos, } \\
\text { spatial distribution of fission products }\end{array}$ \\
\hline
\end{tabular}

\section{A-2. Materials Testing and Qualification- Graphite Technology Development Project}

The nonfuel components in the VHTR reactor core will be primarily graphite. As with test fuels, various graphite formulations will be irradiated in ATR and examined to study performance in a hightemperature, high-neutron-flux environment. In a separate series of experiments, properties of the graphite materials will be studied for different graphite grades.

For the graphite that is tested in ATR, many of the data streams are like the fuel data. In particular, the data streams will include the following:

- Irradiation data (see Table A-7)

- ATR reactor operations data (the data streams are the same as for the fuel; see Table A-4)

- Neutronics and temperature analysis data (same data streams as for the fuel; see Table A-5)

- PIE data (data to provide characterization and safety analysis of graphite after irradiation in ATR will be stored, but a detailed list of response variables has not yet been developed).

The graphite characterization part of the project will generate the data described in Table A-8. 
Table A-7. Reactor irradiation monitoring parameters for the AGC (graphite) experiments.

\begin{tabular}{ll}
\hline Component & \multicolumn{1}{c}{ Response Variables and Attributes. } \\
\hline $\begin{array}{l}\text { Capsule } \\
\text { Channel }\end{array}$ & Temperature from thermocouples, helium, argon, and total gas flow, moisture content \\
Capsule, & $\mathrm{O}_{2}$ concentration measured in the inflow gas; $\mathrm{CO}$ and $\mathrm{CO}_{2}$ monitored in the effluent gas \\
leadout
\end{tabular}

Table A-8. Parameters and classification for graphite specimens (characterization).

\begin{tabular}{cl}
\hline Component & \multicolumn{1}{c}{ Response Variables and Attributes. } \\
\hline Specimen & Physical properties. Thickness, diameter, mass, volume, bulk density. \\
& Elastic modulus. Modulus by time of flight, fundamental frequency, Poisson's ratio. \\
& Electrical properties. Electrical resistivity. \\
& Thermal properties. Instantaneous and mean coefficient of thermal expansion, thermal \\
& diffusivity, specific heat, thermal conductivity. \\
& Mechanical properties. Tensile strength, compressive strength. \\
& Grade, orientation, type, location within billet. \\
& Irradiation location information: position within capsule, channel.
\end{tabular}

\section{A-3. Materials Testing and Qualification- High Temperature Materials Project}

The High Temperature Materials (HTM) data project involves the performance of materials outside the reactor core. A particular focus will be on heat exchanger materials to be used in the design of the reactor-hydrogen interface. Guidelines for approving materials for high-temperature applications ask for tensile strength, yield strength, reduction of area, and elongation at $50^{\circ} \mathrm{C}$-increments from room temperature to $50^{\circ} \mathrm{C}$ above the maximum intended use temperature and over a range of strain rates. Weld strength rupture factors will be determined for two welding processes as a function of time and temperature. Other properties to be measured at elevated temperatures ( $\mathrm{T}$ up to $1,000{ }^{\circ} \mathrm{C}$ ) include elastic modulus, Poisson's Ratio, linear thermal expansion, thermal conductivity, thermal diffusivity, and density. Additional lab investigations will characterize weld creep-fatigue, effect of helium impurities, and aging effects on fracture toughness. Table A-9 (Wright, 2010) gives a list of the test series planned for the HTM project to characterize Alloy $800 \mathrm{H}$ for potential use in steam generators (SG) and Alloy 617 for potential use in intermediate heat exchanger s (IHX). Table A-10 shows test series (Wright, 2010) planned for the HTM project to characterize Alloy A508/A533 for potential use in reactor pressure vessels (RPV). Each series consists of multiple experiments.

Data have been received in NDMAS from the A-1, A-3, A-13A, A-20, and A-22 test series for the IHX/SG alloys and from the A-15 and A-29 RPV alloys. The completed tests (with location marked in the table) fall generally into three categories: creep tests ("Cr"), cyclic tests ("Cy"), and tensile tests ("UT"). Examples of parameters for these tests are listed in Tables A-10 through A-12, respectively. 
Table A-9. Planned HTM tests to characterize alloys for potential use in steam generators (SG) and intermediate heat exchangers (IHX) (PLN-2804) (see Note a).

\begin{tabular}{|c|c|c|c|}
\hline $\begin{array}{c}\text { Test } \\
\text { Series }\end{array}$ & $\begin{array}{l}\text { Test } \\
\text { Loc. }\end{array}$ & $\begin{array}{l}\text { Test } \\
\text { Type }\end{array}$ & Description \\
\hline A-1 & INL & UT & Tensile Tests for $\mathrm{S}_{\mathrm{m}}$ Confirmatory Testing \\
\hline $\mathrm{A}-2$ & - & $\mathrm{Cr}$ & Weld Strength Rupture Factor Determination Test \\
\hline A-3 & - & $\mathrm{Cy}$ & Creep-Fatigue Tests for Alloy 617 Welds \\
\hline A-4 & - & - & Aging Effects on Fracture Toughness of Alloy 617 Wrought Metal \\
\hline A-5 & - & UT & $\begin{array}{l}\text { Tensile Tests to Determine Strain Rate Sensitivity in Support of Unified Constitutive } \\
\text { Model }\end{array}$ \\
\hline A- 6 & - & - & Torsion Tests for Validating Von Mises Criterion to Support Unified Constitutive Model \\
\hline A-7 & - & - & Stress Dip Tests in Support of Unified Constitutive Model \\
\hline A-8 & - & $\mathrm{Cr}$ & Short-term (Days) Creep Tests to Support Unified Constitutive Model \\
\hline A-9 & - & - & Uniaxial Ratcheting Tests to Support Unified Constitutive Model \\
\hline A-10 & - & $\mathrm{Cy}$ & Torsional Cycling with Constant Axial Strain to Support Unified Constitutive Model \\
\hline A-11 & - & $\mathrm{Cr}$ & Loading-Unloading-Creep Sequence to Support Unified Constitutive Model \\
\hline A-12 & - & $\mathrm{Cy}$ & Thermomechanical Cycling to Support Unified Constitutive Model \\
\hline A-13A & INL & $\mathrm{Cr}$ & Creep Curves to Qualify Unified Constitutive Model \\
\hline A-13B & - & - & Stress Relaxation Tests for Qualifying Unified Constitutive Model \\
\hline A-14 & - & UT & Uniaxial Tests on Thermally Aged Alloy 617 to Support Unified Constitutive Model \\
\hline A-15 & - & - & Tube Burst Tests for Alloy 617 and Alloy $800 \mathrm{H}$ \\
\hline A-16 & - & $\mathrm{Cy}$ & Creep-Fatigue Tests for Simplified Model Test (SMT) Specimens \\
\hline A-17 & - & $\mathrm{Cr}$ & Long Term Alloy 617 Creep Rupture Tests for Qualification \\
\hline A-18 & - & UT & Thermal Aging Tests for Strength Reduction Factors \\
\hline A-19 & - & $\mathrm{Cy}$ & Fatigue Tests to Support Design Curve Development in Alloy 617 Code Case \\
\hline A-20 & INL & Cy & $\begin{array}{l}\text { Creep-fatigue Test Matrix to Support Determination of Creep-Fatigue Interaction } \\
\text { Diagram }\end{array}$ \\
\hline A-21 & - & $\mathrm{Cr}$ & $\begin{array}{l}\text { Tests to Determine "C" Factor in Multiaxial Creep Rupture Strength Criterion } \\
\text { for Alloy } 617\end{array}$ \\
\hline A-22 & INL & $\mathrm{Cr}$ & Interrupted Creep Tests \\
\hline A-23 & - & & Creep-Fatigue Saturation with Hold Time \\
\hline A-24 & - & $\mathrm{Cr}$ & Exploration of Creep Mechanisms for Alloy 617 \\
\hline A- 25 & - & $\mathrm{Cr}$ & Determination of Grain Size Rupture Factors for Alloy 617 \\
\hline A-26 & - & UT & Tensile Tests Supporting Unified Constitutive Model for Alloy $800 \mathrm{H}$ \\
\hline A-27 & - & $\mathrm{Cr}$ & Weld Strength Rupture Factor for Alloy $800 \mathrm{H}$ Weldments \\
\hline A-28 & - & UT & Strain Rate Effect on Yield and Tensile Strength for Alloy $800 \mathrm{H}$ \\
\hline A-29 & - & $\mathrm{Cr}$ & Exploration of Creep Mechanisms of Alloy $800 \mathrm{H}$ \\
\hline A-30 & - & UT & $\begin{array}{l}\text { Qualification of Yield and Tensile Strength Reduction Factors for Alloy } 800 \mathrm{H} \\
\text { Due to Thermal Aging }\end{array}$ \\
\hline A-31 & - & - & $\begin{array}{l}\text { Tests to Validate "C" Factor in Multiaxial Creep Rupture Strength Criterion } \\
\text { for Alloy } 800 \mathrm{H}\end{array}$ \\
\hline
\end{tabular}

a. Test locations: West, Westmoreland Mechanical Testing \& Research, Inc.; Dirats, Dirats Laboratories; INL, Idaho National Laboratory; unknown; test not yet performed. Test types: UT, uniaxial tension; CR, creep; Cy, cyclic (creep-fatigue). 
Table A-10. Planned HTM tests to characterize alloys for potential use in reactor pressure vessels (RPV) (PLN-2803) (see Note a).

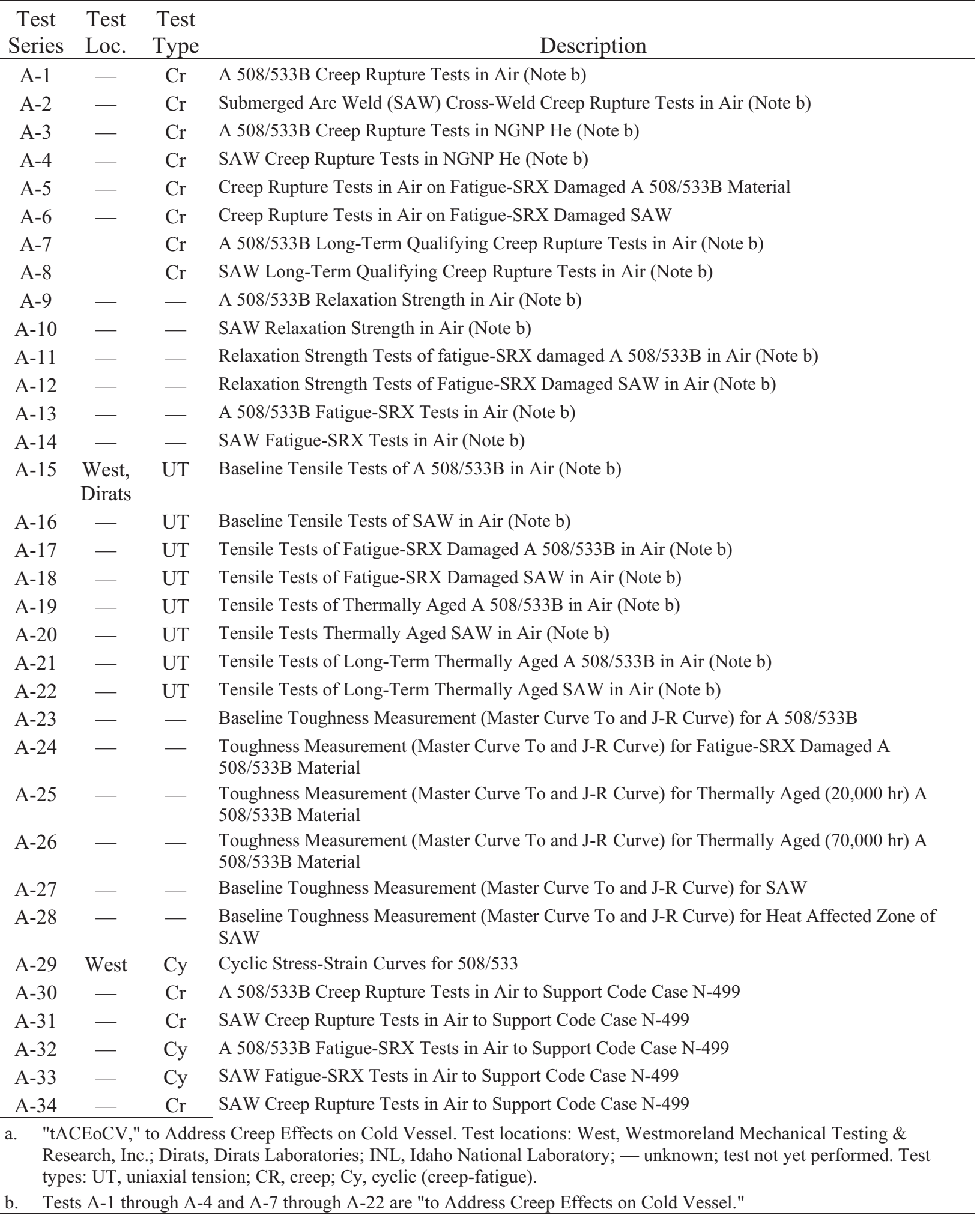


Table A-11. Parameters for HTM Characterization-Uniaxial Tension Tests (SG\&IHX Test A-1).

\begin{tabular}{|c|c|}
\hline Component & Response Variables and Attributes \\
\hline Specimen & Physical properties \\
\hline Specimen & Time, stress, strain \\
\hline Specimen & $\begin{array}{l}\text { Crosshead displacement, force, extensometer } 1 \text { displacement, extensometer } 1 \text { strain, } \\
\text { extensometer } 2 \text { displacement, extensometer } 2 \text { strain, average displacement, average } \\
\text { strain, estimated strain rate, corrected strain }\end{array}$ \\
\hline Specimen & $\begin{array}{l}\text { Test temperature, yield strength, ultimate tensile strength, percent elongation, } \\
\text { percent reduction in area }\end{array}$ \\
\hline Specimen & Final specimen length \\
\hline Specimen & Photographs \\
\hline
\end{tabular}

Table A-12. Parameters for HTM Characterization-Cyclic Creep-Fatigue Tests (SG\&IHX Test A-20).

\begin{tabular}{ll}
\hline \multicolumn{1}{c}{ Component } & \multicolumn{1}{c}{ Response Variables and Attributes } \\
\hline Specimen & Physical properties \\
Specimen & Time, axial count, corrected stress, axial strain, thermocouple (more recent files) \\
Specimen & Axial displacement, axial force, thermocouple (older files) \\
Specimen & Diameter at testing temperature \\
Specimen & Inelastic strain range @ midlife, stable load range, initial/stable stress max, cycles \\
& for initial/stable, cycles to initiation, cycles to failure \\
Specimen & Stress min/max at 2 points per cycle, stress ratio per cycle \\
Specimen & Strain min/max at 2 points per cycle \\
Specimen & Photographs \\
Experiment & Procedure File \\
\hline
\end{tabular}

Table A-13. Parameters for typical HTM Characterization-Creep Tests.

\begin{tabular}{ll}
\hline \multicolumn{1}{c}{ Component } & \multicolumn{1}{c}{ Response Variables and Attributes } \\
\hline Specimen & Physical properties \\
Specimen & Diameter at testing temperature \\
Specimen & Temperature \\
Specimen & Applied stress \\
Specimen & Target percent creep \\
Specimen & Time series data for \% creep (strain), stress, temperature, and extensometer \\
& displacement \\
Specimen & Photographs \\
Experiment & Test logs \\
\hline
\end{tabular}




\section{A-4. Design Methods and Validation Project}

Data collection activities in support of code development and validation include measurement of nuclear interaction cross sections. Nuclear cross-section measurements relevant to the harder neutron spectrum of the VHTR will be made for selected isotopes, particularly ${ }^{240} \mathrm{Pu},{ }^{241} \mathrm{Pu}$, and ${ }^{242} \mathrm{Pu}$. These data will ultimately be incorporated into the Evaluated Nuclear Data Files, but may be retained in NDMAS if deemed appropriate. Other data to be collected include criticality, reactivity feedback coefficients, kinetics parameters, peak power, conversion ratio of sustainable cores, transmutation potential, maximum displacement per atom, decay heat, and radiation levels.

Thermal-hydraulic experiments are aimed at producing validation for computational fluid dynamics and systems analysis codes. The experiments will focus on core heat transfer, fluid behavior in core plenums, reactor cavity cooling, air ingress, and combined effects experiments. Two types of experiments are planned: isothermal fluid dynamics measurements, and heated flow studies. Approximately 20 to 50 new experiments will be required to validate software. Data to be collected include temperature, velocity, and pressure. Optical data collection techniques will also be employed. Very large data files will be created by these experiments to capture the spatial and temporal variation in fluid movement and temperature necessary to validate codes. Specific parameters and data types will be defined for these data streams as funding permits and the research continues.

\section{A-5. High Temperature Electrolysis Research and Development Project}

High temperature electrolysis research and development activities focus on development of hydrogen production options to use the high temperature gases generated by the VHTR. High temperature electrolysis requires low-cost, efficient electricity and an energy source that can produce high temperature steam. The project's focus is on design of nuclear hydrogen systems, optimization of solid-oxide electrolysis cells, and catalysis of hydrogen production using sulfur-based cycles. Response variable lists and data types for data streams associated with this project will be developed as funding permits and further details of the research are defined. 
Appendix B

\section{Table with Row for Every NDMAS Web Portlet}




\section{Appendix B}

\section{Table with Row for Every NDMAS Web Portlet}

Table B-1 through Table B-5 describes the current NDMAS web pages in detail. Table B-1 covers the AGC-1 pages, Table B-2covers AGC-2, Table B-3 covers AGR-1, Table B-4 covers AGR-2, and

Table B-5 describes the HTM pages. All portlets are covered except the qualification portlets and help portlets. 
Table B-1. AGC-1 web page hierarchy and portlets.

\begin{tabular}{|c|c|c|c|c|c|}
\hline \multicolumn{3}{|c|}{ Web Page Hierarchy } & \multirow[b]{2}{*}{ Portlet } & \multirow[b]{2}{*}{ Content Type } & \multirow[b]{2}{*}{ Content } \\
\hline Level 1 & Level 2 & Level 3 & & & \\
\hline \multirow{7}{*}{$\begin{array}{l}\text { AGC-1 } \\
\text { (Ad- } \\
\text { vanced } \\
\text { Graphite } \\
\text { Creep } \\
\text { Test 1) }\end{array}$} & - & - & 1. AGC-1 & Text & Introductory text \\
\hline & \multirow[t]{6}{*}{$\begin{array}{l}\text { CHR } \\
\text { (Charac- } \\
\text { terization) }\end{array}$} & \multirow[t]{6}{*}{-} & \multirow[t]{5}{*}{$\begin{array}{l}\text { 1. AGC-1 } \\
\text { Charac- } \\
\text { terization } \\
\text { Data }\end{array}$} & $\begin{array}{l}\text { Report } \\
\text { showing cube } \\
\text { (graphite } \\
\text { grade >> } \\
\text { specimen } \\
\text { type }>> \\
\text { specimen). } \\
\text { Crosstab } \\
\text { display with } \\
\text { drill-down } \\
\text { capabilities }\end{array}$ & $\begin{array}{l}\text { Graphite pre-irradiation characterization data report. Drill down from graphite } \\
\text { grade summary for the } 15 \text { grades to details by orientation, specimen type, and } \\
\text { specimen number. Report shows physical properties such as diameter, mechanical } \\
\text { properties such as Young's modulus, and thermal/electrical properties such as the } \\
\text { linear thermal expansion coefficient. }\end{array}$ \\
\hline & & & & $\begin{array}{l}\text { Report with } \\
\text { group breaks } \\
\text { on graphite } \\
\text { grade }\end{array}$ & $\begin{array}{l}\text { Report providing graphite coefficient of thermal expansion (CTE) as a function of } \\
\text { temperature }\left(100 \text { to } 800^{\circ} \mathrm{C}\right) \text {. The display includes both tabular data and graphs. The } \\
\text { coefficients are expansion lengths as a percentage of the original length, divided by the } \\
\text { temperature difference to make a rate per degree. Instantaneous rates are calculated } \\
\text { over a small temperature difference, while the 'average' rates are calculated over the } \\
\text { temperature span from room temperature }\left(21^{\circ} \mathrm{C}\right) \text { to the target temperature. }\end{array}$ \\
\hline & & & & Report & $\begin{array}{l}\text { Graphite pre-irradiation characterization data report for specimens installed in the } \\
\text { ATR. The data are organized by installed position in the ATR, including the channel } \\
\text { and midpoint elevation. The parameters included in the "data characterization report" } \\
\text { are shown. }\end{array}$ \\
\hline & & & & Report & $\begin{array}{l}\text { Graphite characterization data report for ATR specimens paired by location } \\
\text { (stressed and not stressed). In separate rows for each "measure," the same physical, } \\
\text { mechanical, and thermal/electrical properties are described as in the original table. } \\
\text { Absolute and percentage differences for matched stressed and unstressed specimens } \\
\text { are given. }\end{array}$ \\
\hline & & & & Report & $\begin{array}{l}\text { Graphite measurement methods and conditions report. The table has a row for } \\
\text { each measured property (physical, mechanical, etc.) }\end{array}$ \\
\hline & & & $\begin{array}{l}\text { 2. HTML Box } \\
\text { Plots }\end{array}$ & $\begin{array}{l}\text { HTML frame } \\
\text { with links to } \\
\text { Active X } \\
\text { plots }\end{array}$ & $\begin{array}{l}\text { Box plots for each parameter grouped by specimen type. In the plots, distributions are } \\
\text { shown for each applicable graphite grade. The plots are selected using a table of } \\
\text { contents on the left. The plots are ActiveX plots. When the mouse hovers over a bar, a } \\
\text { box comes up showing the graphite grade and other statistics associated with the } \\
\text { population described by the box. }\end{array}$ \\
\hline
\end{tabular}


Table B-1. (continued).

\begin{tabular}{|c|c|c|c|c|c|}
\hline \multicolumn{3}{|c|}{ Web Page Hierarchy } & \multirow[b]{2}{*}{ Portlet } & \multirow[b]{2}{*}{ Content Type } & \multirow[b]{2}{*}{ Content } \\
\hline Level 1 & Level 2 & Level 3 & & & \\
\hline \multirow{8}{*}{$\begin{array}{l}\text { AGC-1 } \\
\text { (Ad- } \\
\text { vanced } \\
\text { Graphite } \\
\text { Creep } \\
\text { Test 1) } \\
\text { (cont.) }\end{array}$} & \multirow[t]{8}{*}{$\begin{array}{l}\text { IRR } \\
\text { (Irradia- } \\
\text { tion) }\end{array}$} & \multirow[t]{8}{*}{-} & $\begin{array}{l}\text { 1. AGC-1 } \\
\text { Irradiation } \\
\text { Monitoring }\end{array}$ & Text & AGC-1 irradiation monitoring introductory text. \\
\hline & & & \multirow{6}{*}{$\begin{array}{l}\text { 2. AGC-1 } \\
\text { Irradiation } \\
\text { Monitoring } \\
\text { Data }\end{array}$} & $\begin{array}{l}\text { Link to } \\
\text { HTML } \\
\text { graphs }\end{array}$ & $\begin{array}{l}\text { AGC-1 temperature monitoring link to graphs of TC temperatures at a particular } \\
\text { point in time (marked on the top of the graph), organized by distance from the reactor } \\
\text { centerline and plotted as a function of the date. }\end{array}$ \\
\hline & & & & $\begin{array}{l}\text { Link to } \\
\text { HTML } \\
\text { graphs }\end{array}$ & $\begin{array}{l}\text { Ram pressure, load cells, and stack position link to three plots, with channel data } \\
\text { plotted by date. }\end{array}$ \\
\hline & & & & $\begin{array}{l}\text { Link to } \\
\text { HTML } \\
\text { graphs }\end{array}$ & $\begin{array}{l}\text { Ar/He gas flows for temperature control link to three plots. The first two show inlet } \\
\text { Ar and He gas flows, respectively, inside and outside the shield. The third plot shows } \\
\text { outlet moisture content. The data are shown as a function of date. }\end{array}$ \\
\hline & & & & $\begin{array}{l}\text { Link to } \\
\text { HTML } \\
\text { graphs }\end{array}$ & $\begin{array}{l}\text { Link to HTML graphs of stack raising data. A panel plot exists for a selected period } \\
\text { during each outage, with data overlaid in each panel for the six channels. The panels } \\
\text { show stack positions, raise pressures, loads, and ram pressure. }\end{array}$ \\
\hline & & & & Report & $\begin{array}{l}\text { AGC-1 temperatures report (tables with columns for } 13 \text { TCs and a row for each } 12 \\
\text { hours during an ATR cycle). The data are averages of the detailed readings for the } \\
\text { preceding } 12 \mathrm{~h} \text {. }\end{array}$ \\
\hline & & & & Report & $\begin{array}{l}\text { AGC-1 creep response report (a table for each ATR cycle, with effective power } \\
\text { followed by three columns for each of six channels. The three columns show stack } \\
\text { position, pneumatic ram gas pressure, and compressive stress. The report has a row for } \\
\text { each } 12 \text { hours during the ATR cycle). }\end{array}$ \\
\hline & & & $\begin{array}{l}\text { 3. AGC-1 } \\
\text { Graphical } \\
\text { Summary }\end{array}$ & $\begin{array}{l}\text { HTML } \\
\text { graphs }\end{array}$ & $\begin{array}{l}\text { HTML graphs showing the AGC-1 irradiation history. A single panel shows effective } \\
\text { power by date. The next panel plot shows TC temperatures, organized in panels based } \\
\text { on the distance from the ATR centerline. A third plot shows channel-based stack } \\
\text { positions and loads. The last graph contains a panel for Ar and He gas flows inside the } \\
\text { shield, one for outside the shield, and one for moisture in the outlet gas flow. }\end{array}$ \\
\hline
\end{tabular}


Table B-2. AGC-2 web page hierarchy and portlets.

\begin{tabular}{|c|c|c|c|c|c|}
\hline \multicolumn{3}{|c|}{ Web Page Hierarchy } & \multirow[b]{2}{*}{ Portlet } & \multirow[b]{2}{*}{ Content Type } & \multirow[b]{2}{*}{ Content } \\
\hline Level 1 & Level 2 & Level 3 & & & \\
\hline \multirow{9}{*}{$\begin{array}{l}\text { AGC-2 } \\
\text { (Advanced } \\
\text { Graphite } \\
\text { Creep } \\
\text { Test 2) }\end{array}$} & - & - & $\begin{array}{l}\text { 1. AGC-2 } \\
\text { Irradia- } \\
\text { tion Creep } \\
\text { Experiment }\end{array}$ & Text & Introduction with text and a diagram showing the matrix of planned tests. \\
\hline & $\begin{array}{l}\text { CHR } \\
\text { (Charac- } \\
\text { terization) }\end{array}$ & - & $\begin{array}{l}\text { 1. AGC-2 } \\
\text { Pre-irradiation } \\
\text { Characterizati } \\
\text { on }\end{array}$ & Text & (No data have yet been released) \\
\hline & \multirow[t]{7}{*}{$\begin{array}{l}\text { IRR } \\
\text { (Irradia- } \\
\text { tion) }\end{array}$} & \multirow[t]{7}{*}{-} & $\begin{array}{l}\text { 1. AGC-2 } \\
\text { Irradiation } \\
\text { Monitoring }\end{array}$ & Text & AGC-2 irradiation monitoring introductory text \\
\hline & & & \multirow[t]{4}{*}{$\begin{array}{l}\text { 2. AGC-2 } \\
\text { Irradiation } \\
\text { Monitoring } \\
\text { Data }\end{array}$} & $\begin{array}{l}\text { Report with } 3 \\
\text { sections, } \\
\text { based on } \\
\text { displayed } \\
\text { variables. } \\
\text { Group breaks } \\
\text { on ATR cycle }\end{array}$ & $\begin{array}{l}\text { AGC-2 Load and Displacements report with tables having columns for each channel } \\
\text { and a row for each } 12 \text { hours. Similar to the AGC1 creep response report, but the } \\
\text { different variables (stack position, pneumatic ram gas pressure, and compressive } \\
\text { stress) are accessed using the report sections instead of having all the data in a wide } \\
\text { table view. }\end{array}$ \\
\hline & & & & $\begin{array}{l}\text { Report with } \\
\text { group breaks } \\
\text { on ATR cycle }\end{array}$ & $\begin{array}{l}\text { AGC-2 Thermocouple Temperatures report with tables for each ATR cycle having } \\
\text { columns for each TC }(13 \mathrm{TCs}) \text {. Averages of data for preceding } 12 \text { hours. }\end{array}$ \\
\hline & & & & $\begin{array}{l}\text { Same as } \\
\text { above }\end{array}$ & $\begin{array}{l}\text { AGC-2 Gas Flow Composition report with a table for each ATR cycle having } \\
\text { columns for inside and outside shield Ar and He flow rates and outlet moisture. } \\
\text { Averages of 5- or 10-minute data over the 12-h period ending at the specified date. }\end{array}$ \\
\hline & & & & $\begin{array}{l}\text { Link to } \\
\text { HTML } \\
\text { graphs }\end{array}$ & $\begin{array}{l}\text { Link to Stack Raising Plots. A panel plot exists for a selected period during each } \\
\text { outage, with data overlaid in each panel for the six channels. The panels show stack } \\
\text { positions, raise pressures, loads, and ram pressure. }\end{array}$ \\
\hline & & & $\begin{array}{l}\text { 3. Recent } \\
\text { Temperature } \\
\text { Profile }\end{array}$ & HTML graph & $\begin{array}{l}\text { A graph showing vertical temperature values plotted against the TC position as } \\
\text { measured from the reactor midpoint. The date and time for the temperatures are above } \\
\text { the graph. }\end{array}$ \\
\hline & & & $\begin{array}{l}\text { 4. AGC-2 } \\
\text { Irradiation } \\
\text { Monitoring } \\
\text { Graphs }\end{array}$ & $\begin{array}{l}\text { HTML } \\
\text { graphs }\end{array}$ & $\begin{array}{l}\text { Graphs showing the AGC-2 irradiation history. A single panel shows effective power } \\
\text { by date. The next graph shows TC temperatures, organized in panels based on the } \\
\text { distance from the ATR centerline. A third plot shows channel-based stack positions } \\
\text { and loads. The last graph contains a panel for Ar and He gas flows inside the shield, } \\
\text { one for outside the shield, and one for moisture in the outlet gas flow. }\end{array}$ \\
\hline
\end{tabular}


Table B-3. AGR-1 web page hierarchy and portlets.

\begin{tabular}{|c|c|c|c|c|c|}
\hline \multicolumn{3}{|c|}{ Web Page Hierarchy } & \multirow[b]{2}{*}{ Portlet } & \multirow[b]{2}{*}{ Content Type } & \multirow[b]{2}{*}{ Content } \\
\hline Level 1 & Level 2 & Level 3 & & & \\
\hline \multirow{5}{*}{$\begin{array}{l}\text { AGR-1 } \\
\text { (Advanced } \\
\text { Gas } \\
\text { Reactor } \\
\text { Test 1) }\end{array}$} & \multirow[t]{5}{*}{-} & \multirow[t]{5}{*}{-} & $\begin{array}{l}\text { 1. NGNP } \\
\text { AGR-1 Data } \\
\text { Summary }\end{array}$ & Text & Introductory text. \\
\hline & & & $\begin{array}{l}\text { 2. ATR } \\
\text { Operating } \\
\text { Condition } \\
\text { Graphical } \\
\text { Summary } \\
\end{array}$ & HTML graph & $\begin{array}{l}\text { HTML panel graph showing number of neck shims inserted, depth of regulator rods, } \\
\text { control cylinder angles, and ATR effective power as a function of effective full power } \\
\text { days. }\end{array}$ \\
\hline & & & $\begin{array}{l}\text { 3. AGR-1 } \\
\text { Graphical } \\
\text { Summary }\end{array}$ & $\begin{array}{l}\text { HTML } \\
\text { graphs }\end{array}$ & $\begin{array}{l}\text { HTML panel graph for each of six capsules in the test train, showing TC temperatures, } \\
\text { Ne fraction, physics simulation-based power density in fuel and in the surrounding } \\
\text { graphite, temperature differences between TC measurements and simulated or } \\
\text { modeled temperatures, simulated TC fuel temperatures (minimum, average, and } \\
\text { maximum), R/B ratios for Kr- } 85 \mathrm{~m}, \mathrm{Kr}-88 \text {, and Xe- } 135 \text {, and daily average and } \\
\text { maximum gross gamma counts per } 3.5 \text { seconds. All of these parameters are plotted as } \\
\text { a function of effective full power days (EFPD). }\end{array}$ \\
\hline & & & $\begin{array}{l}\text { 4. Fission } \\
\text { Product } \\
\text { Release by } \\
\text { Capsule and } \\
\text { Cycle }\end{array}$ & HTML graph & $\begin{array}{l}\text { HTML panel graph that shows the R/B ratios for } \mathrm{Kr}-85 \mathrm{~m}, \mathrm{Kr}-88 \text {, and } \mathrm{Xe}-135 \text { plotted } \\
\text { as a function of EFPD. The data are grouped horizontally by capsule and vertically by } \\
\text { ATR cycle. }\end{array}$ \\
\hline & & & $\begin{array}{l}\text { 5. AGR-1 } \\
\text { Cycle } \\
\text { Statistics } \\
\text { Summary }\end{array}$ & $\begin{array}{l}\text { HTML } \\
\text { graphs }\end{array}$ & $\begin{array}{l}\text { HTML graph showing ATR effective power, followed by four panel plots for each } \\
\text { capsule. The first shows TC temperatures, the second shows Ne and He gas flows, the } \\
\text { third shows Ne fraction, and the fourth shows the R/B ratios for Kr- } 85 \mathrm{~m}, \mathrm{Kr}-88 \text {, and } \\
\text { Xe- } 135 \text {. All data are ATR cycle averages, plotted with the ATR cycles on the abscissa. } \\
\text { Each panel also shows maximums from daily cycle averages. Shading provides } 95 \% \\
\text { confidence bounds on the means. }\end{array}$ \\
\hline
\end{tabular}


Table B-3. (continued).

\begin{tabular}{|c|c|c|c|c|c|}
\hline \multicolumn{3}{|c|}{ Web Page Hierarchy } & \multirow[b]{2}{*}{ Portlet } & \multirow[b]{2}{*}{ Content Type } & \multirow[b]{2}{*}{ Content } \\
\hline Level 1 & Level 2 & Level 3 & & & \\
\hline \multirow{4}{*}{$\begin{array}{l}\text { AGR-1 } \\
\text { (Advanced } \\
\text { Gas } \\
\text { Reactor } \\
\text { Test 1) } \\
\text { (cont.) }\end{array}$} & \multirow[t]{4}{*}{$\begin{array}{l}\text { FAB } \\
\text { (Fabri- } \\
\text { cation) }\end{array}$} & \multirow[t]{4}{*}{ - } & $\begin{array}{l}\text { 1. AGR-1 Fuel } \\
\text { Fabrication } \\
\text { Data }\end{array}$ & Text & Introductory text. \\
\hline & & & \multirow[t]{3}{*}{$\begin{array}{l}\text { 2. Fuel } \\
\text { Fabrication } \\
\text { Data } \\
\text { Reports }\end{array}$} & $\begin{array}{l}\text { Static report } \\
\text { with } 11 \\
\text { tables }\end{array}$ & $\begin{array}{l}\text { AGR-1 fuel fabrication components static report. This report contains a series of small } \\
\text { tables, starting with uranium kernel data. There are tables for particle layer data for } \\
\text { each of the four fuel variants used in the experiment. The sixth table gives particle } \\
\text { composite aspect ratios and defect fractions for composites from each of the four } \\
\text { variants. From compact lot samples from each of the four variants, average masses of } \\
\text { various impurities, per compact, are displayed. Finally, four tables (organized by fuel } \\
\text { variant) provide the size, mass, and molding pressure for each compact made. These } \\
\text { data are not set up for downloading. }\end{array}$ \\
\hline & & & & $\begin{array}{l}\text { Static report } \\
\text { with } 11 \\
\text { tables } \\
\text { grouped by } \\
\text { "Type" }\end{array}$ & $\begin{array}{l}\text { Fuel fabrication summary statistics static report. There are tables with statistics for } \\
\text { IPyC layer, OPyC layer, SiC layer, and the buffer layer. Then there are tables for each } \\
\text { layer except the buffer after compacting ("compact IPyC layer," "compact OPyC } \\
\text { layer," and "compact SiC layer"). A table gives impurity statistics for each fuel } \\
\text { variant, using compact lots. Kernel batch, particle composite, and compact lot data } \\
\text { follow, each in its own table. For each table, relevant "response variables" are } \\
\text { described with units, the component they apply to, and the fuel variant. The statistics } \\
\text { are the mean, standard deviation, and number of observations. The tables also give } \\
\text { references for the methods and to the page numbers in the data sources providing the } \\
\text { statistics. }\end{array}$ \\
\hline & & & & $\begin{array}{l}\text { Static report } \\
\text { with } 5 \text { tables }\end{array}$ & $\begin{array}{l}\text { Fuel fabrication methods and conditions static report. Measurement methods and other } \\
\text { information are given for kernel data and for the four fuel variants, each in its own } \\
\text { table. The tables have rows for applicable response variables. Each row gives the } \\
\text { variable's units and description, followed by a method reference and a statement of } \\
\text { conditions for the measurement. }\end{array}$ \\
\hline
\end{tabular}


Table B-3. (continued).

\begin{tabular}{|c|c|c|c|c|c|}
\hline \multicolumn{3}{|c|}{ Web Page Hierarchy } & \multirow[b]{2}{*}{ Portlet } & \multirow[b]{2}{*}{ Content Type } & \multirow[b]{2}{*}{ Content } \\
\hline Level 1 & Level 2 & Level 3 & & & \\
\hline \multirow[t]{7}{*}{$\begin{array}{l}\text { AGR-1 } \\
\text { (Advanced } \\
\text { Gas } \\
\text { Reactor } \\
\text { Test } 1 \text { ) } \\
\text { (cont.) }\end{array}$} & \multirow[t]{7}{*}{$\begin{array}{l}\text { FPM } \\
\text { (Fission } \\
\text { product } \\
\text { mon- } \\
\text { itoring) }\end{array}$} & \multirow[t]{7}{*}{-} & $\begin{array}{l}\text { 1. AGR-1 } \\
\text { Fission } \\
\text { Product } \\
\text { Monitoring } \\
\text { System } \\
\text { (FPMS) } \\
\text { Data }\end{array}$ & Text & $\begin{array}{l}\text { Introductory text with explanations about the nature of the data. R/B ratios are release- } \\
\text { to-birth ratios. }\end{array}$ \\
\hline & & & $\begin{array}{l}\text { 2. FPMS } \\
\text { Release } \\
\text { Data }\end{array}$ & Reports & $\begin{array}{l}\text { A report for each ATR cycle during the AGR- } 1 \text { irradiation, with a table showing } \\
\text { releases and associated errors by date and time for the following isotopes: Kr85m, } \\
\mathrm{Kr} 87, \mathrm{Kr} 88, \mathrm{Kr} 89, \mathrm{Dr} 90, \mathrm{Xe} 131 \mathrm{~m}, \mathrm{Xe} 133, \mathrm{Xe} 135, \mathrm{Xe} 137, \mathrm{Xe} 138 \text {, and Xe139. The } \\
\text { data are recorded approximately every } 8 \text { hours. There is also a table with detailed } \\
\text { capsule outlet gas flows for the six capsules (reported approximately every } 10 \\
\text { minutes). }\end{array}$ \\
\hline & & & $\begin{array}{l}\text { 3. FPMS R/B } \\
\text { Data }\end{array}$ & Reports & $\begin{array}{l}\text { A report for each ATR cycle during the AGR-1 irradiation, with a table showing R/B } \\
\text { ratios and associated errors by date and time for Kr85m, Kr87, Kr88, Kr89, Dr90, } \\
\text { Xe131m, Xe133, Xe135, Xe137, Xe138, and Xe139. The data are recorded } \\
\text { approximately every } 8 \text { hours. }\end{array}$ \\
\hline & & & \multirow{4}{*}{$\begin{array}{l}\text { 4. Release Rate } \\
\text { Plots and } \\
\text { Distributions }\end{array}$} & $\begin{array}{l}\text { Link to } \\
\text { HTML graph }\end{array}$ & $\begin{array}{l}\text { Link to data plot of release rates. The graph contains a panel for each capsule with } \\
\mathrm{Kr} 85 \mathrm{~m}, \mathrm{Kr} 88 \text {, and Xe135 release rates as a function of date. }\end{array}$ \\
\hline & & & & $\begin{array}{l}\text { Link to } \\
\text { HTML graph }\end{array}$ & $\begin{array}{l}\text { Link to box plots of release rates - all cycles. The graph contains a panel for each } \\
\text { capsule with box plots of } \mathrm{Kr} 85 \mathrm{~m}, \mathrm{Kr} 88 \text {, and Xe135 release rate data for each ATR } \\
\text { cycle during the experiment. }\end{array}$ \\
\hline & & & & $\begin{array}{l}\text { Link to } \\
\text { HTML graph }\end{array}$ & $\begin{array}{l}\text { Link to } 2 \text { nd box plot of release rates. The Kr85m box plots from the previous link } \\
\text { are displayed on a single graph with six plotting positions for each ATR cycle (one for } \\
\text { each capsule). The capsule data are connected and color coded to facilitate comparison } \\
\text { of the rates from capsule to capsule. }\end{array}$ \\
\hline & & & & $\begin{array}{l}\text { Link to JMP } \\
\text { histograms, } \\
\text { quantiles, \& } \\
\text { moments by } \\
\text { ATR cycle }\end{array}$ & $\begin{array}{l}\text { Link to the "Data Distribution of [ }[\mathbf{L o g}] \text { Release Rates" listing. It contains } \\
\text { histograms, quantiles, and moments of the log release data for Kr85m, Kr88, and } \\
\text { Xe135, for each ATR cycle during the irradiation. }\end{array}$ \\
\hline
\end{tabular}


Table B-3. (continued).

\begin{tabular}{|c|c|c|c|c|c|}
\hline \multicolumn{3}{|c|}{ Web Page Hierarchy } & \multirow[b]{2}{*}{ Portlet } & \multirow[b]{2}{*}{ Content Type } & \multirow[b]{2}{*}{ Content } \\
\hline Level 1 & Level 2 & Level 3 & & & \\
\hline \multirow{8}{*}{$\begin{array}{l}\text { AGR-1 } \\
\text { (Advanced } \\
\text { Gas } \\
\text { Reactor } \\
\text { Test } 1 \text { ) } \\
\text { (cont.) }\end{array}$} & \multirow{8}{*}{$\begin{array}{l}\text { FPM } \\
\text { (Fission } \\
\text { product } \\
\text { mon- } \\
\text { itoring) } \\
\text { (cont.) }\end{array}$} & & \multirow{5}{*}{$\begin{array}{l}\text { 5. R/B Plots } \\
\text { and } \\
\text { Distributions }\end{array}$} & $\begin{array}{l}\text { Link to } \\
\text { HTML graph }\end{array}$ & $\begin{array}{l}\text { Link to data plot of R/Bs. The graph contains a panel for each capsule with } \mathrm{Kr} 85 \mathrm{~m} \text {, } \\
\mathrm{Kr} 88 \text {, and Xe135 R/B ratios as a function of date. }\end{array}$ \\
\hline & & & & $\begin{array}{l}\text { Link to } \\
\text { HTML graph }\end{array}$ & $\begin{array}{l}\text { Link to } 2 \text { nd plot of R/Bs with reactor cycles. The graph contains a panel for each } \\
\text { capsule with Kr85m, Kr88, and Xe135 R/B ratios as a function of EFPD. }\end{array}$ \\
\hline & & & & $\begin{array}{l}\text { Link to } \\
\text { HTML graph }\end{array}$ & $\begin{array}{l}\text { Link to box plots of R/B - all cycles. The graph contains a panel for each capsule with } \\
\text { box plots of } \mathrm{Kr} 85 \mathrm{~m}, \mathrm{Kr} 88 \text {, and Xe135 R/B data for each ATR cycle during the } \\
\text { experiment. }\end{array}$ \\
\hline & & & & $\begin{array}{l}\text { Link to } \\
\text { HTML graph }\end{array}$ & $\begin{array}{l}\text { Link to } 2 \text { nd box plot of } \mathbf{R} / \mathbf{B s} \text {. The } \mathrm{Kr}-85 \mathrm{~m} \text { box plots from the previous link are } \\
\text { displayed on a single graph with six plotting positions for each ATR cycle (one for } \\
\text { each capsule). The capsule data are connected and color coded to facilitate comparison } \\
\text { of the R/Bs from capsule to capsule. }\end{array}$ \\
\hline & & & & $\begin{array}{l}\text { Link to JMP } \\
\text { histograms, } \\
\text { quantiles, \& } \\
\text { moments by } \\
\text { ATR cycle }\end{array}$ & $\begin{array}{l}\text { Link to the "Data Distribution of }[\mathbf{L o g}] \mathbf{R} / \mathbf{B s} \text { " listing. It contains histograms, } \\
\text { quantiles, and moments of the log R/B data for Kr85m, Kr88, and Xe135, for each } \\
\text { ATR cycle during the irradiation. }\end{array}$ \\
\hline & & & \multirow[t]{3}{*}{$\begin{array}{l}\text { 6. FPMS - } \\
\text { Irradiation } \\
\text { Data } \\
\text { Analysis }\end{array}$} & $\begin{array}{l}\text { Link to } \\
\text { HTML graph }\end{array}$ & $\begin{array}{l}\text { Link to the "Kr-85m R/B vs. TC1 temp" graph. It has vertical panels for each ATR } \\
\text { cycle during the irradiation, with three scatter plots in each panel. The plots show R/Bs } \\
\text { as a function of the temperature reading from the first TC in each capsule (TC_1). } \\
\text { Capsules } 1 \text { and } 2 \text { are not represented in the plot because their "TC1" TCs failed early } \\
\text { in the irradiation. }\end{array}$ \\
\hline & & & & $\begin{array}{l}\text { Link to JMP } \\
\text { regressions \& } \\
\text { tables by } \\
\text { ATR cycle }\end{array}$ & $\begin{array}{l}\text { Link to the "Fit_Kr85m_Rat_TC1" listing. It contains scatter plots and fitted } \\
\text { regression lines for each ATR cycle. The lines describe log (Kr85m release rate) as a } \\
\text { function of the TC1 temperature. Data for each capsule's regression line are provided } \\
\text { (the equation, a summary of the fit, and the analysis of variance table). This series of } \\
\text { results is presented sequentially for each ATR cycle during the irradiation. }\end{array}$ \\
\hline & & & & Report & $\begin{array}{l}\text { A report with a table listing daily averages by date for the AGR- } 1 \text { capsules. The } \\
\text { averages are for effective power, capsule-specific He and Ne inlet flow rates and the } \\
\text { outlet flow rate, and } \mathrm{R} / \mathrm{B} \text { ratios and releases for } \mathrm{Kr} 85 \mathrm{~m}, \mathrm{Kr} 88 \text {, and } \mathrm{Kr} 135 \text {. The report } \\
\text { also includes temperatures for TC } 1 \text { and TC } 3 \text {, as applicable, in the capsules and the } \\
\text { average of the log } \mathrm{Kr} 85 \mathrm{~m} \text { values. The data are filtered to exclude capsule-days for } \\
\text { which the effective power is less than } 20 \mathrm{MW} \text {, or the } \mathrm{Kr}-85 \mathrm{~m} \mathrm{R} / \mathrm{B} \text { ratio is missing or } \\
\text { less than } 1 . \mathrm{E}-10 \text {, or the He flow rate is less than } 20 \mathrm{sccm} \text {, or the TC- } 1 \text { temperature is } \\
\text { present but less than } 600^{\circ} \mathrm{C} \text {. Also data for the first ATR cycle in the experiment (Cycle } \\
\text { 138B) are not included. }\end{array}$ \\
\hline
\end{tabular}


Table B-3. (continued).

\begin{tabular}{|c|c|c|c|c|c|}
\hline \multicolumn{3}{|c|}{ Web Page Hierarchy } & \multirow[b]{2}{*}{ Portlet } & \multirow[b]{2}{*}{ Content Type } & \multirow[b]{2}{*}{ Content } \\
\hline Level 1 & Level 2 & Level 3 & & & \\
\hline \multirow[t]{4}{*}{$\begin{array}{l}\text { AGR-1 } \\
\text { (Advanced } \\
\text { Gas } \\
\text { Reactor } \\
\text { Test 1) } \\
\text { (cont.) }\end{array}$} & $\begin{array}{l}\text { GG } \\
\text { (Gross } \\
\text { gamma } \\
\text { counts) }\end{array}$ & - & $\begin{array}{l}\text { 1. Interactive } \\
\text { gross } \\
\text { gamma plots } \\
\text { for } \\
\text { AGR-1 }\end{array}$ & $\begin{array}{l}\text { Link to } \\
\text { stored } \\
\text { processes that } \\
\text { generate } \\
\text { graphs as } \\
\text { specified by } \\
\text { users }\end{array}$ & $\begin{array}{l}\text { Following text with background information about the gross gamma data, there are } \\
\text { links to two SAS "stored processes." One plots AGR-1 gross gamma data for a period } \\
\text { of } 1 \text { to } 23 \text { hours, while the other plots the data for one or more days. After clicking on } \\
\text { one of these links, a screen comes up that allows the user to specify the gross gamma } \\
\text { detector of interest and the starting date for the plot. As applicable, the user also } \\
\text { indicates the starting hour, number of hours, or the ending date. A graph appears with } \\
\text { the gross gamma counts for } 3.5 \text {-sec. intervals. If the plot spans more than one day, the } \\
\text { data are thinned to reduce the large number of data values and allow the plot to render } \\
\text { in a short amount of time. The maximum and minimum values of the data (in the } \\
\text { upper } 0.05 \text { and lower } 0.05 \text { percentage of the selected data) are always plotted so that } \\
\text { extreme values can be shown. }\end{array}$ \\
\hline & \multirow{3}{*}{$\begin{array}{l}\text { IRR } \\
\text { (Irradia- } \\
\text { tion) }\end{array}$} & & 1. AGR-1 IRR & Text & Introductory text. \\
\hline & & & $\begin{array}{l}\text { 2. AGR-1 } \\
\text { individual } \\
\text { cycles }\end{array}$ & $\begin{array}{l}\text { Reports } \\
\text { showing cube } \\
\text { (capsule, } \\
\text { ATR cycle, } \\
\text { and a time } \\
\text { hierarchy: } \\
\text { Year >> } \\
\text { Month }>> \\
\text { Day }>>\text { Hour). } \\
\text { Crosstab } \\
\text { display with } \\
\text { drill-down } \\
\text { capabilities }\end{array}$ & $\begin{array}{l}\text { Reports are listed for each ATR cycle. They contain a plot for ATR hourly average } \\
\text { effective power, followed by panel plots showing average He and Ne flows, average } \\
\text { TC temperatures, and maximum log R/B ratios. In each of the panel plots, there are six } \\
\text { panels, one for each capsule. The plots all have drill-down features related to the } \\
\text { embedded time hierarchy. For example, clicking on a day (along the X axis of a graph) } \\
\text { and "expanding" makes the display show the aggregated data at an hourly level for the } \\
24 \text { hours of the day. The graphs are followed by a downloadable data table which is } \\
\text { synchronized with the plots. If the plots are expanded to show hourly data for a day, } \\
\text { the data table will also show hourly data for that day. }\end{array}$ \\
\hline & & & $\begin{array}{l}\text { 3. AGR-1 all } \\
\text { cycles by } \\
\text { capsules }\end{array}$ & $\begin{array}{l}\text { Same as } \\
\text { above }\end{array}$ & $\begin{array}{l}\text { Reports are listed for each capsule. They contain a plot for ATR hourly average } \\
\text { effective power, followed by plots showing He and Ne flows, TC temperatures, and } \\
\text { log R/B ratios. The plots all have drill-down features related to the embedded time } \\
\text { hierarchy. The user can view aggregated monthly data or more detailed daily or hourly } \\
\text { data. The graphs are followed by a downloadable data table. }\end{array}$ \\
\hline
\end{tabular}


Table B-3. (continued).

\begin{tabular}{|c|c|c|c|c|c|}
\hline \multicolumn{3}{|c|}{ Web Page Hierarchy } & \multirow[b]{2}{*}{ Portlet } & \multirow[b]{2}{*}{ Content Type } & \multirow[b]{2}{*}{ Content } \\
\hline Level 1 & Level 2 & Level 3 & & & \\
\hline \multirow{8}{*}{$\begin{array}{l}\text { AGR-1 } \\
\text { (Advanced } \\
\text { Gas } \\
\text { Reactor } \\
\text { Test } 1 \text { ) } \\
\text { (cont.) }\end{array}$} & \multirow{8}{*}{$\begin{array}{l}\text { PHY } \\
\text { (Physics) } \\
\text { (Neu- } \\
\text { tronics \& } \\
\text { thermal } \\
\text { simu- } \\
\text { lations) }\end{array}$} & \multirow[t]{8}{*}{ - } & 1. Information & Text & Introductory text. \\
\hline & & & \multirow{5}{*}{$\begin{array}{l}\text { 2. Plots of } \\
\text { AGR-1 } \\
\text { simulation } \\
\text { results }\end{array}$} & $\begin{array}{l}\text { Link to } \\
\text { HTML graph }\end{array}$ & $\begin{array}{l}\text { Link to the "ATR power history" graph, which shows effective full power days } \\
\text { (EFPD) as a function of calendar time. }\end{array}$ \\
\hline & & & & $\begin{array}{l}\text { Link to } \\
\text { HTML graph }\end{array}$ & $\begin{array}{l}\text { Link to the "AGR-1 fuel fission power density" plot. The panel plot shows the } \\
\text { simulated average heat for the fuel in each capsule as a function of EFPD. }\end{array}$ \\
\hline & & & & $\begin{array}{l}\text { Link to } \\
\text { HTML graph }\end{array}$ & $\begin{array}{l}\text { Link to the "AGR-1 fuel fission power density trend" plot, which shows a smoothed } \\
\text { version of the simulated average heat data for the six capsules as overlay curves on } \\
\text { one graph. }\end{array}$ \\
\hline & & & & $\begin{array}{l}\text { Link to } \\
\text { HTML graph }\end{array}$ & $\begin{array}{l}\text { Link to the "AGR-1 fuel burnup" plot. Six panels show the simulated average, } \\
\text { maximum and minimum fuel burnup as a function of EFPD for each capsule. The } \\
\text { aggregated data are computed using the simulated daily burnup values at two locations } \\
\text { in each of the } 12 \text { compacts in a capsule. }\end{array}$ \\
\hline & & & & $\begin{array}{l}\text { Link to } \\
\text { HTML graph }\end{array}$ & $\begin{array}{l}\text { Link to the "AGR-1 fast neutron fluence" plot. Six panels show the simulated } \\
\text { average, maximum and minimum fast neutron fluence as a function of EFPD for each } \\
\text { capsule. The aggregated data are computed using the simulated daily fluence values at } \\
\text { two locations in each of the } 12 \text { compacts in a capsule. }\end{array}$ \\
\hline & & & $\begin{array}{l}\text { 3. MCNP end- } \\
\text { of-cycle } \\
\text { neutronics } \\
\text { simulation } \\
\text { data }\end{array}$ & Reports & $\begin{array}{l}\text { Three reports, one for each of the fuel compact stacks that run through the capsules in } \\
\text { the test train. Cumulative burnup, fluence, and fission power data are provided for two } \\
\text { nodes in each compact for the dates that correspond to ends of ATR cycles during the } \\
\text { irradiation. }\end{array}$ \\
\hline & & & $\begin{array}{l}\text { 4. JMOCUP } \\
\text { daily } \\
\text { neutronics } \\
\text { simulation } \\
\text { data }\end{array}$ & Reports & $\begin{array}{l}\text { Six reports: one with simulated daily powers as a function of effective full power days } \\
\text { (EFPD); three with stack power data, one with "CD" power data, and a final report } \\
\text { with "HEAT" data. The stack data contain cumulative effective full power days and } \\
\text { simulated daily average burnup, fluence, and fission power data for the two nodes in } \\
\text { each compact for each day. The "CD" report has simulated component heat rates (in } \\
\text { W/cc) for various materials in the capsules for each day. Finally, the HEAT report has } \\
\text { simulated daily capsule fission power densities. }\end{array}$ \\
\hline
\end{tabular}


Table B-3. (continued).

\begin{tabular}{|c|c|c|c|c|c|}
\hline \multicolumn{3}{|c|}{ Web Page Hierarchy } & \multirow[b]{2}{*}{ Portlet } & \multirow[b]{2}{*}{ Content Type } & \multirow[b]{2}{*}{ Content } \\
\hline Level 1 & Level 2 & Level 3 & & & \\
\hline \multirow[t]{4}{*}{$\begin{array}{l}\text { AGR-1 } \\
\text { (Advanced } \\
\text { Gas } \\
\text { Reactor } \\
\text { Test 1) } \\
\text { (cont.) }\end{array}$} & $\begin{array}{l}\text { PHY } \\
\text { (Physics) } \\
\text { (Neu- } \\
\text { tronics \& } \\
\text { thermal } \\
\text { simu- } \\
\text { lations) } \\
\text { (cont.) }\end{array}$ & & $\begin{array}{l}\text { 5. ABAQUS } \\
\text { daily } \\
\text { thermal } \\
\text { simulation }\end{array}$ & Reports & $\begin{array}{l}\text { Four component-level reports with simulated temperatures: one for compacts, one for } \\
\text { stacks, one for capsules, and one for the TCs in the experiment. The compact data set } \\
\text { has a record for each compact for each day, with the average, maximum and minimum } \\
\text { values for simulated fuel temperature ("Sft"). It also shows time averages ("SFT Ta") } \\
\text { of the averages, maximums, and minimums. These are averages of each of the three } \\
\text { daily Sft statistics from the start of the experiment up to the day corresponding to the } \\
\text { record. The stack data cite the same statistics at a stack level (aggregated over the } 4 \\
\text { compacts in each stack), while the "CAP" report shows daily capsule values. Finally, } \\
\text { the TC file gives simulated daily average temperatures at the TC locations in each } \\
\text { capsule. }\end{array}$ \\
\hline & \multirow{3}{*}{$\begin{array}{l}\text { PIE } \\
\text { (Post- } \\
\text { irradia- } \\
\text { tion } \\
\text { exami- } \\
\text { nation) }\end{array}$} & \multirow{3}{*}{ - } & 1. AGR-1/PIE & Text & $\begin{array}{l}\text { Introductory text about the post irradiation examination data, which currently contains } \\
\text { length and diameter measurements. }\end{array}$ \\
\hline & & & $\begin{array}{l}\text { 2. Metrology } \\
\text { data mart }\end{array}$ & Reports & $\begin{array}{l}\text { Three reports, one describing compact dimensions, one for graphite holder } \\
\text { dimensions, and one for the graphite holder holes. }\end{array}$ \\
\hline & & & $\begin{array}{l}\text { 3. Metrology } \\
\text { native Excel } \\
\text { files }\end{array}$ & $\begin{array}{l}\text { Links to } \\
\text { Excel files }\end{array}$ & $\begin{array}{l}\text { Links to Excel files showing the measurements along with digital images of the } \\
\text { components. There are } 4 \text { compacts in each of } 3 \text { stacks in each of } 6 \text { capsules, making a } \\
\text { total of } 72 \text { compacts in the irradiation. Each was measured, rotated } 120 \text { degrees, } \\
\text { measured again, and rotated once more and measured. The compact data thus consist } \\
\text { of } 216 \text { Excel files. Five of the six capsule holders were also measured three times } \\
\text { (with rotation in between). (The holder for Capsule } 4 \text { could not be measured because it } \\
\text { could not be removed from the test train intact). There are } 15 \text { Excel files for the holder } \\
\text { measurements. Finally, there are links to } 5 \text { graphite holder summary files. }\end{array}$ \\
\hline
\end{tabular}


Table B-3. (continued).

\begin{tabular}{|c|c|c|c|c|c|}
\hline \multicolumn{3}{|c|}{ Web Page Hierarchy } & \multirow[b]{2}{*}{ Portlet } & \multirow[b]{2}{*}{ Content Type } & \multirow[b]{2}{*}{ Content } \\
\hline Level 1 & Level 2 & Level 3 & & & \\
\hline \multirow{5}{*}{$\begin{array}{l}\text { AGR-1 } \\
\text { (Advanced } \\
\text { Gas } \\
\text { Reactor } \\
\text { Test 1) } \\
\text { (cont.) }\end{array}$} & \multirow{5}{*}{$\begin{array}{l}\text { Analysis } \\
(\mathrm{TC} \\
\text { relia- } \\
\text { bility) }\end{array}$} & \multirow[t]{5}{*}{-} & $\begin{array}{l}\text { 1. AGR-1 } \\
\text { analysis } \\
\text { introduction }\end{array}$ & Text & $\begin{array}{l}\text { Introductory text, including a table with dates of thermocouple (TC) failures and a } \\
\text { figure illustrating where the TCs were installed in the capsules. }\end{array}$ \\
\hline & & & $\begin{array}{l}\text { 2. AGR-1 pair } \\
\text { TC } \\
\text { temperatures } \\
\text { and within- } \\
\text { capsule } \\
\text { correlation }\end{array}$ & $\begin{array}{l}\text { HTML } \\
\text { graphs }\end{array}$ & $\begin{array}{l}\text { HTML graphs for each pair of TCs within each capsule. The plots have } 4 \text { panels: a } \\
\text { control chart showing differences in the TC readings and in simulated temperatures for } \\
\text { the TC pair; a panel showing daily average differences in TC readings and simulated } \\
\text { TC readings for each TC; correlations calculated from the detailed daily readings; and } \\
\text { the actual daily average observed and simulated temperatures. The data are plotted as a } \\
\text { function of date. }\end{array}$ \\
\hline & & & $\begin{array}{l}\text { 3. AGR-1 } \\
\text { junction } \\
\text { detection by } \\
\text { correlation } \\
\text { analysis }\end{array}$ & $\begin{array}{l}\text { HTML } \\
\text { graphs }\end{array}$ & $\begin{array}{l}\text { HTML graphs for each capsule, with a panel for each TC. The panels show daily } \\
\text { answers to the question: What capsule contains the TC whose readings are most highly } \\
\text { correlated with the panel's TC? The expected answer to this question is the same } \\
\text { capsule (marked with a red line in the plots) as the panel TC being evaluated. When } \\
\text { another capsule has the most correlated TC over a period of time, the possibility of a } \\
\text { junction exists (where the panel TC's reading is influenced by that capsule's } \\
\text { temperatures). }\end{array}$ \\
\hline & & & $\begin{array}{l}\text { 4. AGR-1 } \\
\text { correlation } \\
\text { cycle } \\
\text { statistics }\end{array}$ & $\begin{array}{l}\text { HTML } \\
\text { graphs }\end{array}$ & $\begin{array}{l}\text { HTML graphs for each capsule, with a panel for each TC. The panels contain box } \\
\text { plots for each ATR cycle during the irradiation. The data forming the distributions is } \\
\text { the daily correlations of the panel TC and all other TCs in the same capsule during the } \\
\text { ATR cycle. Ideally, the plots would show tight distributions near } 1 \text {. }\end{array}$ \\
\hline & & & $\begin{array}{l}\text { 5. Daily } \\
\text { averaged TC } \\
\text { readings and } \\
\text { cycle } \\
\text { statistics }\end{array}$ & $\begin{array}{l}\text { HTML } \\
\text { graphs }\end{array}$ & $\begin{array}{l}\text { HTML graphs for each capsule, with a panel for each TC. The panels show daily } \\
\text { average TC readings as a scatter plot. For each ATR cycle, the average of the daily } \\
\text { values is represented as a step plot. The width of shading around the step plot for each } \\
\text { TC and cycle corresponds to the estimated standard deviation of that TC's daily } \\
\text { averages for the cycle. }\end{array}$ \\
\hline
\end{tabular}


Table B-3. (continued).

\begin{tabular}{|c|c|c|c|c|c|}
\hline \multicolumn{3}{|c|}{ Web Page Hierarchy } & \multirow[b]{2}{*}{ Portlet } & \multirow[b]{2}{*}{ Content Type } & \multirow[b]{2}{*}{ Content } \\
\hline Level 1 & Level 2 & Level 3 & & & \\
\hline \multirow[t]{6}{*}{$\begin{array}{l}\text { AGR-1 } \\
\text { (Advanced } \\
\text { Gas } \\
\text { Reactor } \\
\text { Test } 1 \text { ) } \\
\text { (cont.) }\end{array}$} & \multirow[t]{6}{*}{$\begin{array}{l}\text { Fuel } \\
\text { Sum- } \\
\text { mary }\end{array}$} & \multirow[t]{6}{*}{-} & $\begin{array}{l}\text { 1. Fuel } \\
\text { compact } \\
\text { summary }\end{array}$ & Text & $\begin{array}{l}\text { Introductory text. "FAB," "FPM," "PHY," and "PIE" compact data are matched by } \\
\text { compact. Data are presented based on a compact's location in the AGR-1 test train. } \\
\text { From left to right, the vertical position goes from high (Capsule 6, Level 4) to low } \\
\text { (Capsule 1, Level 1). The horizontal position of a compact depends on which "stack" } \\
\text { it is in. Stack data are plotted separately. Data from each of the } 72 \text { irradiated compacts } \\
\text { show on the graphs. }\end{array}$ \\
\hline & & & 2. Data table & Report & Report providing access to the content displayed in the four portlets below. \\
\hline & & & $\begin{array}{l}\text { 3. Fuel } \\
\text { compact } \\
\text { irradiation } \\
\text { data }\end{array}$ & HTML graph & $\begin{array}{l}\text { HTML graph with panels for simulated average fuel temperatures (instantaneous, } \\
\text { time-average peak, and time-average volume-average), burnup, fast fluence, and R/B } \\
\text { ratios. Each panel has plotted data for each stack except the R/B data (which are } \\
\text { calculated from simulated birth rates and are capsule averages). }\end{array}$ \\
\hline & & & $\begin{array}{l}\text { 4. Fuel } \\
\text { compact } \\
\text { dimensions }\end{array}$ & $\begin{array}{l}\text { HTML } \\
\text { graphs }\end{array}$ & $\begin{array}{l}\text { Three graphs with metrology data. The first shows compact shrinkage (PIE size minus } \\
\text { fabrication size as a \% of fabrication size). Diameter shrinkage and length shrinkage } \\
\text { are in two panels. The Stack } 1 \text { plot has shading showing the standard deviation of the } \\
\text { mean from the percentage differences (from PIE measurements at different } \\
\text { orientations and positions on each compact). The second graph in the portlet shows the } \\
\text { as-built and PIE average diameters. The PIE maximum and minimum diameters are } \\
\text { also shown. The third graph is like the second except that it shows lengths. }\end{array}$ \\
\hline & & & $\begin{array}{l}\text { 5. Fuel } \\
\text { compact } \\
\text { fabrication } \\
\text { data }\end{array}$ & HTML graph & $\begin{array}{l}\text { In successive panels, individual compact mass and molding pressures are displayed; } \\
\text { followed by variant-average OPyC anisotropy and U loading. The last two panels } \\
\text { show variant-level masses of various impurities in the IPyC, OPyC, SiC and Buffer } \\
\text { layers. }\end{array}$ \\
\hline & & & $\begin{array}{l}\text { 6. Fuel particle } \\
\text { fabrication } \\
\text { data }\end{array}$ & HTML graph & $\begin{array}{l}\text { Successive panels in this graph present fuel variant-level average particle aspect ratios; } \\
\text { thicknesses of the IPyC, OPyC, and SiC layers; sink-float based density measures for } \\
\text { these layers and the buffer layer; and layer coating temperatures, gas flow rates, and } \\
\text { gas fractions. The last panel shows coating times for the IPyC, OPyC, and buffer } \\
\text { layers. The variant data are plotted as horizontal lines on the same axes as the compact } \\
\text { data since each capsule's compacts are from the same fuel variant. }\end{array}$ \\
\hline
\end{tabular}


Table B-4. AGR-2 web page hierarchy and portlets.

\begin{tabular}{|c|c|c|c|c|c|}
\hline \multicolumn{3}{|c|}{ Web Page Hierarchy } & \multirow[b]{2}{*}{ Portlet } & \multirow[b]{2}{*}{ Content Type } & \multirow[b]{2}{*}{ Content } \\
\hline Level 1 & Level 2 & Level 3 & & & \\
\hline \multirow{7}{*}{$\begin{array}{l}\text { AGR-2 } \\
(\text { Ad- } \\
\text { vanced } \\
\text { Gas } \\
\text { Reactor } \\
\text { Test 2) }\end{array}$} & \multirow[t]{5}{*}{-} & \multirow[t]{5}{*}{-} & $\begin{array}{l}\text { 1. AGR-2 data } \\
\text { summary }\end{array}$ & Text & $\begin{array}{l}\text { Introductory text with figures showing TC positions and the positions of the } \\
\text { AGR-2 test train in the ATR core. }\end{array}$ \\
\hline & & & $\begin{array}{l}\text { 2. ATR operating } \\
\text { parameters and } \\
\text { Ne fractions - } \\
\text { daily averages }\end{array}$ & Report & $\begin{array}{l}\text { Report with a table that combines ATR conditions with capsule neon fraction, He } \\
\text { flow, Ne flow, and outlet flows. The table is wide, with a record for each day. The } \\
\text { table contains the particular ATR operating parameters and capsule data needed } \\
\text { for input to the thermal and physics models. }\end{array}$ \\
\hline & & & $\begin{array}{l}\text { 3. ATR operating } \\
\text { conditions } \\
\text { graphical } \\
\text { summary } \\
\end{array}$ & HTML graph & $\begin{array}{l}\text { HTML panel graph showing number of neck shims inserted, depth of regulator } \\
\text { rods, control cylinder angles, and ATR effective power as a function of date. }\end{array}$ \\
\hline & & & $\begin{array}{l}\text { 4. AGR-2 } \\
\text { graphical } \\
\text { summary }\end{array}$ & $\begin{array}{l}\text { HTML } \\
\text { graphs }\end{array}$ & $\begin{array}{l}\text { HTML panel graph for each capsule in the test train, showing Ne fraction, TC } \\
\text { temperatures, R/B ratios, gross gamma counts (per } 3.5 \mathrm{sec} \text { ), and gas flows by date. }\end{array}$ \\
\hline & & & $\begin{array}{l}\text { 5. AGR-2 } \\
\text { graphical } \\
\text { summary for } \\
\text { current cycle }\end{array}$ & $\begin{array}{l}\text { HTML } \\
\text { graphs }\end{array}$ & $\begin{array}{l}\text { HTML panel graph for each capsule in the test train, showing Ne fraction, TC } \\
\text { temperatures, R/B ratios, gross gamma counts (per } 3.5 \mathrm{sec} \text { ), and gas flows by date } \\
\text { for the most recent ATR cycle. }\end{array}$ \\
\hline & \multirow[t]{2}{*}{$\begin{array}{l}\text { FAB } \\
\text { (Fabri- } \\
\text { cation) }\end{array}$} & & 1. Introduction & Text & $\begin{array}{l}\text { Introductory text. For AGR-2, fuel processing is presented in terms of } 4 \text { "LEUs" } \\
\text { instead of "fuel variants." "LEUs" are the low enriched } U \text { sources used to make } \\
\text { the fuel kernels. Most of the displays have data for three of the LEUs because } \\
\text { different parameters were measured for the fourth. Also, access to the data for the } \\
\text { certain LEUs is restricted due to CRADA agreements. The exact content visible to } \\
\text { users depends on each user's access credentials. }\end{array}$ \\
\hline & & & 2. Anisotropy & $\begin{array}{l}\text { Displayed } \\
\text { report with } 2 \\
\text { "cube" tables. } \\
\text { Crosstab } \\
\text { display with } \\
\text { averaged } \\
\text { data. Drill- } \\
\text { down to mea- } \\
\text { surements }\end{array}$ & $\begin{array}{l}\text { Two tables provide anisotropy and diattenuation values, one for the inner pyrolitic } \\
\text { carbon layer (IPyC) and one for the outer (OPyC). The tables are collapsed } \\
\text { "cubes" with one record for each LEU. The records show averaged measurements } \\
\text { before and after compacting the coated particles. Clicking on a "+" or " } K \text { " next to } \\
\text { a LEU expands the table to show the detailed data being averaged. }\end{array}$ \\
\hline
\end{tabular}


Table B-4. (continued).

\begin{tabular}{|c|c|c|c|c|c|}
\hline \multicolumn{3}{|c|}{ Web Page Hierarchy } & \multirow[b]{2}{*}{ Portlet } & \multirow[b]{2}{*}{ Content Type } & \multirow[b]{2}{*}{ Content } \\
\hline Level 1 & Level 2 & Level 3 & & & \\
\hline \multirow[t]{8}{*}{$\begin{array}{l}\text { AGR-2 } \\
\text { (Ad- } \\
\text { vanced } \\
\text { Gas } \\
\text { Reactor } \\
\text { Test 2) } \\
\text { (cont.) }\end{array}$} & \multirow{6}{*}{\multicolumn{2}{|c|}{$\begin{array}{l}\text { FAB } \\
\text { (Fabri- } \\
\text { cation) } \\
\text { (cont.) }\end{array}$}} & 3. Aspect ratio & $\begin{array}{l}\text { Displayed } \\
\text { report with } \\
\text { graph. The } \\
\text { plotted data } \\
\text { are down- } \\
\text { loadable }\end{array}$ & $\begin{array}{l}\text { A plot with two aspect ratio histograms, one for particles and one for overcoated } \\
\text { particles. The paired bars show how the histogram shifts with overcoating. The } \\
\text { plots are given in panels, applying to the LEUs with data. Each observation was } \\
\text { counted in the histogram interval with a strictly lower bound on the left and a } \\
\text { greater-than-or-equal-to bound on the right. }\end{array}$ \\
\hline & & & $\begin{array}{l}\text { 4. Particle } \\
\text { contaminants }\end{array}$ & $\begin{array}{l}\text { Displayed } \\
\text { report }\end{array}$ & $\begin{array}{l}\text { Table showing defect fractions for three layers [IPyC, OPyC, and silicon carbide } \\
\text { (SiC)] and U contamination fractions for LEUs with data. The data include the } \\
\text { sample size, the number of "equivalent particles," the fraction, and the upper } \\
\text { bound specification that the fractions should not exceed. }\end{array}$ \\
\hline & & & $\begin{array}{l}\text { 5. Compact } \\
\text { impurities }\end{array}$ & $\begin{array}{l}\text { Displayed } \\
\text { report with } \\
\text { crosstab table }\end{array}$ & $\begin{array}{l}\text { Table showing } U \text { loading and impurity masses per compact for LEUs. The table is } \\
\text { a summary with mean values, number of samples, and the standard deviations. }\end{array}$ \\
\hline & & & $\begin{array}{l}\text { 6. Matrix } \\
\text { impurities }\end{array}$ & $\begin{array}{l}\text { Displayed } \\
\text { report }\end{array}$ & $\begin{array}{l}\text { Table showing impurity fractions in ppmw for LEUs with data. The data are } \\
\text { provided for the natural graphite, synthetic matrix, and heat-treated matrix for } \\
\text { each of the LEUs. }\end{array}$ \\
\hline & & & 7. Summary data & $\begin{array}{l}\text { Displayed } \\
\text { report with } \\
\text { crosstab table }\end{array}$ & $\begin{array}{l}\text { Table showing sizes and other component parameters for the LEUs. Data are } \\
\text { present for the kernels, for the buffer, IPyC, OPyc, and } \mathrm{SiC} \text { layers, for particle } \\
\text { composites, for overcoated particle composites, and for compact lots. }\end{array}$ \\
\hline & & & 8. Compact data & $\begin{array}{l}\text { Report. } \\
\text { Crosstab } \\
\text { table with } 8 \\
\text { sections. }\end{array}$ & $\begin{array}{l}\text { Report w/sections providing carbonization and heat treatment process data for } \\
\text { kernel lots; size, density, packing fraction, and other data for the compacts from } \\
\text { the LEUs, and diameters for the compacts from the LEUs with data. }\end{array}$ \\
\hline & \multirow{2}{*}{$\begin{array}{l}\text { FPM } \\
\text { (Fission } \\
\text { product } \\
\text { moni- } \\
\text { toring) }\end{array}$} & \multirow[t]{2}{*}{ - } & $\begin{array}{l}\text { 1. AGR2- FPMS } \\
\text { release and R/B } \\
\text { data page } \\
\text { summary }\end{array}$ & Text & Introductory text. \\
\hline & & & $\begin{array}{l}\text { 2. FPMS } \\
\text { processing data }\end{array}$ & Report & $\begin{array}{l}\text { Report with very detailed outlet gas flow rates for each capsule. The rates are by } \\
\text { date and time from April 11, } 2011 \text { forward. The rates were recorded each minute. } \\
\text { The data are input to FPMS post-processing. }\end{array}$ \\
\hline
\end{tabular}


Table B-4. (continued).

\begin{tabular}{|c|c|c|c|c|c|}
\hline \multicolumn{3}{|c|}{ Web Page Hierarchy } & \multirow[b]{2}{*}{ Portlet } & \multirow[b]{2}{*}{ Content Type } & \multirow[b]{2}{*}{ Content } \\
\hline Level 1 & Level 2 & Level 3 & & & \\
\hline \multirow[t]{7}{*}{$\begin{array}{l}\text { AGR-2 } \\
\text { (Ad- } \\
\text { vanced } \\
\text { Gas } \\
\text { Reactor } \\
\text { Test 2) } \\
\text { (cont.) }\end{array}$} & \multirow{3}{*}{\multicolumn{2}{|c|}{$\begin{array}{l}\text { FPM } \\
\text { (Fission } \\
\text { product } \\
\text { moni- } \\
\text { toring) } \\
\text { (cont.) }\end{array}$}} & $\begin{array}{l}\text { 3. FPMS data } \\
\text { mart - release } \\
\text { rates }\end{array}$ & $\begin{array}{l}\text { Reports, and } \\
\text { a link to a } \\
\text { HTML graph }\end{array}$ & $\begin{array}{l}\text { A report for each ATR cycle during the AGR-2 irradiation, with a table showing } \\
\text { releases and associated errors by date and time for the following isotopes: Kr85m, } \\
\mathrm{Kr} 87, \mathrm{Kr} 88, \mathrm{Kr} 89, \mathrm{Kr} 90, \mathrm{Xe} 131 \mathrm{~m}, \mathrm{Xe1} 33, \mathrm{Xe135} \text {, Xe137, Xe138, and Xe139. } \\
\text { The data are recorded approximately every } 8 \text { hours. There is also a table with the } \\
\text { same data for all the ATR cycles in the irradiation (which would be a more } \\
\text { convenient download source if all the cycle data were desired). Finally, there is a } \\
\text { link to the "AGR-2 Release Rate Plot." The graph contains a panel for each } \\
\text { capsule with Kr85m, Kr88, and Xe135 release rates as a function of date. }\end{array}$ \\
\hline & & & $\begin{array}{l}\text { 4. FPMS data } \\
\text { mart }-\mathrm{R} / \mathrm{B} \\
\text { ratios }\end{array}$ & $\begin{array}{l}\text { Reports, and } \\
\text { a link to a } \\
\text { HTML graph }\end{array}$ & $\begin{array}{l}\text { A report for each ATR cycle during the AGR-2 irradiation, with a table showing } \\
\text { R/B ratios and associated errors by date and time for Kr85m, Kr87, Kr88, Kr89, } \\
\text { Dr90, Xe131m, Xe133, Xe135, Xe137, Xe138, and Xe139. The data are recorded } \\
\text { approximately every } 8 \text { hours. There is also a table with the same data for all the } \\
\text { ATR cycles in the irradiation (which would be a more convenient download } \\
\text { source if all the cycle data were desired). Finally, there is a link to the "AGR-2 } \\
\text { R/B Plot." The graph contains a panel for each capsule with Kr85m, Kr88, and } \\
\text { Xe135 release rates as a function of date. }\end{array}$ \\
\hline & & & $\begin{array}{l}\text { 5. R/B plot - all } \\
\text { cycles }\end{array}$ & HTML graph & $\begin{array}{l}\text { HTML graph of R/B data for all cycles. The graph contains a panel for each } \\
\text { capsule with } \mathrm{Kr} 85 \mathrm{~m}, \mathrm{Kr} 88 \text {, and } \mathrm{Xe} 135 \mathrm{R} / \mathrm{B} \text { ratios as a function of date. }\end{array}$ \\
\hline & \multirow{4}{*}{$\begin{array}{l}\text { GG } \\
\text { (Gross } \\
\text { gamma } \\
\text { counts) }\end{array}$} & \multirow[t]{4}{*}{ - } & $\begin{array}{l}\text { 1. AGR-2 gross } \\
\text { gamma plots }\end{array}$ & Text & Introductory text. \\
\hline & & & $\begin{array}{l}\text { 2. Gross gamma } \\
\text { for the last } 24 \\
\text { hours }\end{array}$ & $\begin{array}{l}\text { Links to } \\
\text { HTML } \\
\text { graphs }\end{array}$ & $\begin{array}{l}\text { Links to HTML graphs for each detector showing the gross gamma counts (per } \\
3.5 \mathrm{sec} \text { ) for the most recent } 24 \mathrm{~h} \text { for which data exists. }\end{array}$ \\
\hline & & & $\begin{array}{l}\text { 3. Gross gamma } \\
\text { for the last } 7 \\
\text { days }\end{array}$ & $\begin{array}{l}\text { Links to } \\
\text { HTML } \\
\text { graphs }\end{array}$ & $\begin{array}{l}\text { Links to HTML graphs for each detector showing the gross gamma counts (per } \\
3.5 \mathrm{sec} \text { ) for the most recent seven days for which data exists. To have less than } \\
25,000 \text { data points on the graph, the data are thinned (every } 7 \text { th value is plotted). } \\
\text { The maximum and minimum values of the data (in the upper } 0.05 \text { and lower } 0.05 \\
\text { percentage of the selected data) are always plotted. }\end{array}$ \\
\hline & & & $\begin{array}{l}\text { 4. Daily statistics } \\
\text { for gross } \\
\text { gamma by } \\
\text { capsule }\end{array}$ & HTML graph & $\begin{array}{l}\text { HTML panel graph showing the daily average and daily maximum gross gamma } \\
\text { count (per } 3.5 \mathrm{sec} \text { ). The graph contains a panel for each detector. }\end{array}$ \\
\hline
\end{tabular}


Table B-4. (continued).

\begin{tabular}{|c|c|c|c|c|c|}
\hline \multicolumn{3}{|c|}{ Web Page Hierarchy } & \multirow[b]{2}{*}{ Portlet } & \multirow[b]{2}{*}{ Content Type } & \multirow[b]{2}{*}{ Content } \\
\hline Level 1 & Level 2 & Level 3 & & & \\
\hline \multirow[t]{4}{*}{$\begin{array}{l}\text { AGR-2 } \\
\text { (Ad- } \\
\text { vanced } \\
\text { Gas } \\
\text { Reactor } \\
\text { Test 2) } \\
\text { (cont.) }\end{array}$} & $\begin{array}{l}\text { GG } \\
\text { (Gross } \\
\text { gamma } \\
\text { counts) } \\
\text { (cont.) }\end{array}$ & & $\begin{array}{l}\text { 5. AGR-2 } \\
\text { interactive } \\
\text { gross gamma } \\
\text { plots }\end{array}$ & $\begin{array}{l}\text { Link to stored } \\
\text { processes that } \\
\text { generate } \\
\text { graphs as } \\
\text { specified by } \\
\text { users }\end{array}$ & $\begin{array}{l}\text { Following text with background information about the gross gamma data, there } \\
\text { are links to two SAS "stored processes." One plots AGR- } 2 \text { gross gamma data for } \\
\text { a period of } 1 \text { to } 23 \text { hours, while the other plots the data for one or more days. } \\
\text { After clicking on one of these links, a screen comes up that allows the user to } \\
\text { specify the gross gamma detector of interest and the starting date for the plot. As } \\
\text { applicable, the user also indicates the starting hour, number of hours, or the } \\
\text { ending date. A graph appears with the gross gamma counts for } 3.5 \text {-sec. intervals. } \\
\text { If the plot spans more than one day, the data are thinned to reduce the large } \\
\text { number of data values and allow the plot to render in a short amount of time. The } \\
\text { maximum and minimum values of the data (in the upper } 0.05 \text { and lower } 0.05 \\
\text { percentage of the plotted data) are always plotted so that extreme values can be } \\
\text { shown. }\end{array}$ \\
\hline & \multirow{3}{*}{$\begin{array}{l}\text { IRR } \\
\text { (Irradia- } \\
\text { tion) }\end{array}$} & \multirow[t]{3}{*}{ - } & 1. AGR-2/IRR & Text & Introductory text. \\
\hline & & & $\begin{array}{l}\text { 2. AGR-2 } \\
\text { individual } \\
\text { cycles_PLOTS }\end{array}$ & $\begin{array}{l}\text { Reports } \\
\text { showing cube } \\
\text { (capsule, } \\
\text { ATR cycle, } \\
\text { and a time } \\
\text { hierarchy: } \\
\text { Year }>> \\
\text { Month>> } \\
\text { Day>>Hour). } \\
\text { Crosstab } \\
\text { display with } \\
\text { drill-down } \\
\text { capabilities }\end{array}$ & $\begin{array}{l}\text { Report links are listed for each ATR cycle. They contain a plot for ATR average } \\
\text { effective power, followed by panel plots showing average He and Ne flows, } \\
\text { average TC temperatures, and maximum log R/B ratios. In each of the panel plots, } \\
\text { there are panels for each capsule. The plots all have drill-down features related to } \\
\text { the embedded time hierarchy. The user can view aggregated monthly data or more } \\
\text { detailed daily or hourly data. The graphs are followed by a downloadable data } \\
\text { table that is synchronized with the plots. Expanding a time period either on a plot } \\
\text { or in the data table causes it to be expanded in both. }\end{array}$ \\
\hline & & & $\begin{array}{l}\text { 3. AGR-2 } \\
\text { individual } \\
\text { cycles_DATA }\end{array}$ & $\begin{array}{l}\text { Same as } \\
\text { above }\end{array}$ & $\begin{array}{l}\text { Reports links are present for each ATR cycle. Each contains a data table with } \\
\text { ATR hourly average effective power, He and Ne flows, TC temperatures, and R/B } \\
\text { ratios for all of the AGR- } 2 \text { capsules. The data have drill-down features related to } \\
\text { the embedded time hierarchy. The user can view averages of monthly data or } \\
\text { more detailed daily or hourly data. }\end{array}$ \\
\hline
\end{tabular}


Table B-4. (continued).

\begin{tabular}{|c|c|c|c|c|c|}
\hline \multicolumn{3}{|c|}{ Web Page Hierarchy } & \multirow[b]{2}{*}{ Portlet } & \multirow[b]{2}{*}{ Content Type } & \multirow[b]{2}{*}{ Content } \\
\hline Level 1 & Level 2 & Level 3 & & & \\
\hline \multirow[t]{7}{*}{$\begin{array}{l}\text { AGR-2 } \\
\text { (Ad- } \\
\text { vanced } \\
\text { Gas } \\
\text { Reactor } \\
\text { Test 2) } \\
\text { (cont.) }\end{array}$} & \multirow[t]{2}{*}{$\begin{array}{l}\text { IRR } \\
\text { (Irradia- } \\
\text { tion) } \\
\text { (cont.) }\end{array}$} & & $\begin{array}{l}\text { 4. AGR-2 all } \\
\text { cycles by } \\
\text { capsule- } \\
\text { PLOTS }\end{array}$ & $\begin{array}{l}\text { Same as } \\
\text { above }\end{array}$ & $\begin{array}{l}\text { Report links are listed for each AGR-2 capsule. They contain a plot for ATR } \\
\text { average effective power, followed by plots showing average He and Ne flows, } \\
\text { average TC temperatures, and maximum log R/B ratios for the selected capsule. } \\
\text { The plots have drill-down features related to the embedded time hierarchy. The } \\
\text { user can view aggregated monthly data or more detailed daily or hourly data. The } \\
\text { graphs are followed by a downloadable data table that is synchronized with the } \\
\text { plots. Expanding a time period either on a plot or in the data table causes it to be } \\
\text { expanded in both. }\end{array}$ \\
\hline & & & $\begin{array}{l}\text { 5. AGR-2 all } \\
\text { cycles by } \\
\text { capsule_DATA }\end{array}$ & $\begin{array}{l}\text { Same as } \\
\text { above }\end{array}$ & $\begin{array}{l}\text { Report links are present for each AGR-2 capsule. Each contains a data table with } \\
\text { ATR average effective power, He and Ne flows, TC temperatures, and R/B ratios. } \\
\text { The data have drill-down features related to the embedded time hierarchy. The } \\
\text { user can view averages of monthly data or more detailed daily or hourly averages. }\end{array}$ \\
\hline & \multirow[t]{5}{*}{ Analysis } & - & $\begin{array}{l}\text { 1. AGR-2 analysis } \\
\text { home }\end{array}$ & Text & Introductory text. \\
\hline & & \multirow[t]{4}{*}{$\begin{array}{l}\text { Gas } \\
\text { Flows }\end{array}$} & $\begin{array}{l}\text { 1. AGR-2 gas } \\
\text { flows - } \\
\text { introduction }\end{array}$ & Text & Introductory text. \\
\hline & & & $\begin{array}{l}\text { 2. Ne flow for } \\
\text { capsules with } \\
\text { no operating } \\
\text { TCs }\end{array}$ & $\begin{array}{l}\text { HTML } \\
\text { graphs }\end{array}$ & $\begin{array}{l}\text { HTML graphs for Capsules } 2 \text { and } 5 \text { showing daily average Ne, Ne+He, and } \\
\text { capsule outlet gas flow rates for the current ATR cycle. These data provide a } \\
\text { context for the main display in the graphs, which is a series of regression- } \\
\text { predicted Ne flow rates (blue dots) and projections of the regression predictions } \\
\text { (purple circles) that are suggested Ne flow rates for the capsules. The regression } \\
\text { models use gas flows in capsules with temperature measurements to estimate gas } \\
\text { flows for Capsule } 2 \text { and for Capsule } 5 \text {, both of which have all failed TCs. The } \\
\text { projection for each day extends the two previous day's regression estimates } \\
\text { forward in a line. To be conservative, the suggested flow rate is the minimum of } \\
\text { the previous day's suggested rate and the projection value (because higher Ne } \\
\text { flow rates reduce the heat transfer out of the capsule). The regression models were } \\
\text { established using data from early in the experiment before the TC failures } \\
\text { occurred. }\end{array}$ \\
\hline & & & 3. Neon fraction & HTML graph & $\begin{array}{l}\text { A HTML panel graph showing daily average Ne fractions for the six capsules as a } \\
\text { function of date since the start of the AGR-2 irradiation. }\end{array}$ \\
\hline & & & 4. Gas flows & HTML graph & $\begin{array}{l}\text { HTML panel graph showing daily average capsule gas flows }(\mathrm{Ne}, \mathrm{He}, \mathrm{Ne}+\mathrm{He} \text {, } \\
\text { and the capsule outlet) as a function of date. }\end{array}$ \\
\hline
\end{tabular}


Table B-4. (continued).

\begin{tabular}{|c|c|c|c|c|c|}
\hline \multicolumn{3}{|c|}{ Web Page Hierarchy } & \multirow[b]{2}{*}{ Portlet } & \multirow[b]{2}{*}{ Content Type } & \multirow[b]{2}{*}{ Content } \\
\hline Level 1 & Level 2 & Level 3 & & & \\
\hline \multirow{8}{*}{$\begin{array}{l}\text { AGR-2 } \\
\text { (Advanc } \\
\text { ed } \\
\text { Gas } \\
\text { Reactor } \\
\text { Test 2) } \\
\text { (cont.) }\end{array}$} & \multirow[t]{8}{*}{$\begin{array}{l}\text { Analysis } \\
\text { (cont.) }\end{array}$} & \multirow{2}{*}{$\begin{array}{l}\text { Gas } \\
\text { Flows } \\
\text { (cont.) }\end{array}$} & $\begin{array}{l}\text { 5. TC } \\
\text { temperatures }\end{array}$ & HTML graph & $\begin{array}{l}\text { HTML panel graph showing the average daily TC temperature readings from the } \\
\text { beginning of the irradiation as a function of date. }\end{array}$ \\
\hline & & & $\begin{array}{l}\text { 6. Gas flows data } \\
\text { — daily } \\
\text { averages }\end{array}$ & Report & $\begin{array}{l}\text { A report containing a downloadable data table with daily average effective power, } \\
\text { leadout Ne and He flow rates, and capsule-specific gas flows (Ne, He, and outlet) } \\
\text { and Ne fraction as a function of date and time for the AGR-2 irradiation period. } \\
\text { Data are filtered to exclude gas flow data when the reactor power is less than } 0.1 \\
\text { MW. Data during reactor outages are combined into single records. }\end{array}$ \\
\hline & & \multirow[t]{6}{*}{$\begin{array}{l}\text { Tempera- } \\
\text { tures }\end{array}$} & $\begin{array}{l}\text { 1. Temperature } \\
\text { data analysis }\end{array}$ & Text & $\begin{array}{l}\text { Introductory text, including a table with dates of thermocouple (TC) failures and a } \\
\text { figure illustrating where the TCs were installed in the capsules. }\end{array}$ \\
\hline & & & $\begin{array}{l}\text { 2. TC } \\
\text { temperatures }\end{array}$ & HTML graph & HTML graph with a panel for each capsule showing TC temperatures by date. \\
\hline & & & $\begin{array}{l}\text { 3. TC drift } \\
\text { detection from } \\
\text { within-capsule } \\
\text { comparisons }\end{array}$ & $\begin{array}{l}\text { HTML } \\
\text { graphs }\end{array}$ & $\begin{array}{l}\text { HTML graphs for each pair of TCs within each capsule. The plots have } 3 \text { panels: } \\
\text { a control chart showing differences in the TC readings for the TC pair; a panel } \\
\text { showing correlations calculated from the detailed daily readings; and the actual } \\
\text { daily average observed temperatures. The data are plotted as a function of date. }\end{array}$ \\
\hline & & & $\begin{array}{l}\text { 4. TC junction } \\
\text { detection using } \\
\text { daily } \\
\text { correlations }\end{array}$ & $\begin{array}{l}\text { HTML } \\
\text { graphs }\end{array}$ & $\begin{array}{l}\text { HTML graphs for each capsule, with a panel for each TC. The panels show daily } \\
\text { answers to the question: What capsule contains the TC whose readings are most } \\
\text { highly correlated with the panel's TC? The expected answer to this question is the } \\
\text { same capsule (marked with a red line in the plots) as the panel TC being } \\
\text { evaluated. When another capsule has the most correlated TC over a period of } \\
\text { time, the possibility of a junction exists (where the panel TC's reading is } \\
\text { influenced by that capsule's temperatures). }\end{array}$ \\
\hline & & & $\begin{array}{l}\text { 5. TC junction } \\
\text { detection using } \\
\text { correlations } \\
\text { between control } \\
\text { TCs } \\
\end{array}$ & $\begin{array}{l}\text { HTML } \\
\text { graphs }\end{array}$ & $\begin{array}{l}\text { HTML graphs for each pair of control TCs (from different capsules). The top } \\
\text { panel shows daily correlation coefficients based on the underlying } 5 \text { or } 10 \text {-minute } \\
\text { temperature pairs, while the bottom panel shows the daily average temperatures. } \\
\text { Since the TCs are in different capsules, the values are expected to differ. A series } \\
\text { of correlations near } 1 \text { might be caused by a junction. }\end{array}$ \\
\hline & & & $\begin{array}{l}\text { 6. Daily average } \\
\text { TC } \\
\text { temperatures } \\
\text { with cycle } \\
\text { statistics }\end{array}$ & $\begin{array}{l}\text { HTML } \\
\text { graphs }\end{array}$ & $\begin{array}{l}\text { HTML graphs for each capsule, with a panel for each TC. The panels show daily } \\
\text { average TC readings as a scatter plot. For each ATR cycle, the average of the } \\
\text { daily values is represented as a step plot. The width of shading around the step } \\
\text { plot for each TC and ATR cycle corresponds to the estimated standard deviation } \\
\text { of that TC's daily averages for the cycle. }\end{array}$ \\
\hline
\end{tabular}


Table B-5. HTM web hierarchy and portlets.

\begin{tabular}{|c|c|c|c|c|c|}
\hline \multicolumn{3}{|c|}{ Web Page Hierarchy } & \multirow[b]{2}{*}{ Portlet } & \multirow[b]{2}{*}{ Content Type } & \multirow[b]{2}{*}{ Content } \\
\hline Level 1 & Level 2 & Level 3 & & & \\
\hline \multirow{4}{*}{$\begin{array}{l}\text { HTM } \\
\text { (High } \\
\text { tem- } \\
\text { perature } \\
\text { materials) }\end{array}$} & - & - & $\begin{array}{l}\text { 1. High } \\
\text { temperature } \\
\text { materials } \\
\text { testing }\end{array}$ & Text & Introductory text about high temperature materials characterization. \\
\hline & \multirow[t]{3}{*}{$\begin{array}{l}\text { SG \& IHX } \\
\text { (Steam } \\
\text { generator } \\
\text { \& inter- } \\
\text { mediate } \\
\text { heat } \\
\text { exchanger) }\end{array}$} & - & $\begin{array}{l}\text { 1. Steam } \\
\text { generator } \\
\text { and } \\
\text { interme- } \\
\text { diate heat } \\
\text { exchanger }\end{array}$ & Text & $\begin{array}{l}\text { Introductory text about characterization of Alloy } 617 \text { (for possible use in intermediate } \\
\text { heat exchangers) and Alloy } 800 \mathrm{H} \text { (for use in steam generators). The set of planned test } \\
\text { series for these materials, from PLN-2804 (R. Wright, 2010), is listed. }\end{array}$ \\
\hline & & \multirow[t]{2}{*}{$\begin{array}{l}\text { Creep } \\
\text { tests }\end{array}$} & $\begin{array}{l}\text { 1. Creep } \\
\text { testing }\end{array}$ & Text & Introductory text about creep testing for Alloys 617 and $800 \mathrm{H}$. \\
\hline & & & $\begin{array}{l}\text { 2. Creep } \\
\text { tests for } \\
\text { Alloy } 617\end{array}$ & $\begin{array}{l}\text { HTML tabs } \\
\text { with links to } \\
\text { embedded } \\
\text { graphs, data } \\
\text { tables, and } \\
\text { stored } \\
\text { processes that } \\
\text { support user- } \\
\text { specified } \\
\text { graphics and } \\
\text { data } \\
\text { downloads }\end{array}$ & $\begin{array}{l}\text { In two tabs, data from two of the listed tests are shown: Interrupted Creep (from } \\
\text { PLN-2804 Test Series A-22), and Creep Rupture (from PLN-2804 Test Series A- } \\
\text { 13A). For each of these tests, data are shown for a series of alloy samples. The left } \\
\text { side of the screen is a navigation menu; clicking an entry will bring up (on the right } \\
\text { side) a graph and a place to click to download the associated data as a comma- } \\
\text { separated values file. The samples are distinguished by the temperature and applied } \\
\text { stress associated with their test. The graphs show percent strain versus time for each } \\
\text { sample. Also, for each test series, on the lower left a link leads to an interactive plot. } \\
\text { Here, the user specifies condition(s) of interest for one or more of } 3 \text { or } 4 \text { variables: } \\
\text { sample, temperature, applied stress, and, for the interrupted creep test series, target } \\
\text { creep. When the user clicks on the "Run" link, the underlying data are filtered } \\
\text { according to the specifications, and an overlay plot is produced showing the } \\
\text { time/strain data for the sample(s) that meet the criteria. }\end{array}$ \\
\hline
\end{tabular}


Table B-5. (continued).

\begin{tabular}{|c|c|c|c|c|c|}
\hline \multicolumn{3}{|c|}{ Web Page Hierarchy } & \multirow[b]{2}{*}{ Portlet } & \multirow[b]{2}{*}{ Content Type } & \multirow[b]{2}{*}{ Content } \\
\hline Level 1 & Level 2 & Level 3 & & & \\
\hline \multirow{5}{*}{$\begin{array}{l}\text { HTM } \\
\text { (High } \\
\text { tem- } \\
\text { perature } \\
\text { materials) } \\
\text { (cont.) }\end{array}$} & \multirow{5}{*}{$\begin{array}{l}\text { SG \& } \\
\text { IHX } \\
\text { (cont.) }\end{array}$} & \multirow[t]{3}{*}{$\begin{array}{l}\text { Cyclic } \\
\text { tests }\end{array}$} & $\begin{array}{l}\text { 1. Cyclic } \\
\text { testing }\end{array}$ & Text & Introductory text about cyclic testing for Alloy 617. \\
\hline & & & $\begin{array}{l}\text { 2. Baseline } \\
\text { creep- } \\
\text { fatigue } \\
\text { tests on } \\
\text { Alloy } 617\end{array}$ & $\begin{array}{l}\text { HTML tabs } \\
\text { with links to } \\
\text { embedded } \\
\text { graphs, data } \\
\text { tables, and } \\
\text { stored } \\
\text { processes that } \\
\text { support data } \\
\text { downloads }\end{array}$ & $\begin{array}{l}\text { Three tabs with data from PLN-2804 Test Series A-20. The test series was conducted } \\
\text { in air at a temperature of } 950^{\circ} \mathrm{C} \text {. The tabs show Hysteresis Loops, Peak and Valley } \\
\text { Stresses, and a Summary. In the first two tabs, the screen is divided into two parts, a } \\
\text { navigation panel and a graph panel. The Navigation panel lists the tested alloy sample } \\
\text { IDs, along with relevant test conditions (the \% strain, type of weld, and hold time). } \\
\text { Clicking on a sample ID makes the graph in the panel on the right show test data for } \\
\text { that sample. The hysteresis graphs show loops of stress as a function of increasing and } \\
\text { decreasing strain for selected unstressed / pulled / unstressed / compressed strain } \\
\text { cycles during the test. The peak and valley stress plots show a sample's minimum and } \\
\text { maximum strains as a function of the strain cycle number. The plots also contain links } \\
\text { to SAS stored processes that download the associated sample hysteresis data or peak } \\
\text { stress data. The last tab contains a table describing the sampling conditions } \\
\text { (temperature, strain range, and hold time) for each sample. Sample results include the } \\
\text { inelastic strain range at midlife, the stable load range, and the minimum and maximum } \\
\text { initial stable stresses. The number of cycles to initial stability, to initiation of fatigue } \\
\text { damage, and to failure are also given. }\end{array}$ \\
\hline & & & $\begin{array}{l}\text { 3. Creep- } \\
\text { fatigue } \\
\text { tests on } \\
\text { welded } \\
\text { Alloy } 617\end{array}$ & Same as above & $\begin{array}{l}\text { Three tabs with data from PLN-2804 Test Series A-3, which deals with cross welded } \\
\text { Alloy } 617 \text { samples. The organization of the content and the nature of the displays are } \\
\text { identical to the previous portlet ("Baseline creep-fatigue testing on Alloy } 617 \text { "). }\end{array}$ \\
\hline & & \multirow[t]{2}{*}{$\begin{array}{l}\text { Tensile } \\
\text { tests }\end{array}$} & $\begin{array}{l}\text { 1. Tensile } \\
\text { testing }\end{array}$ & Text & $\begin{array}{l}\text { Introductory text about tensile testing for Alloys } 617 \text { and } 800 \mathrm{H} \text { to determine allowable } \\
\text { stress limits. }\end{array}$ \\
\hline & & & $\begin{array}{l}\text { 2. Strength } \\
\text { tests }\end{array}$ & $\begin{array}{l}\text { HTML tabs } \\
\text { with links to } \\
\text { embedded } \\
\text { graphs, data } \\
\text { tables, and } \\
\text { stored } \\
\text { processes that } \\
\text { support data } \\
\text { downloads }\end{array}$ & $\begin{array}{l}\text { Five tabs with data from PLN-2804 Test Series A-1. The first contains a sample-level } \\
\text { summary table showing sample ID, test temperature, and four outputs: ultimate tensile } \\
\text { strength, yield strength, \% elongation, and \% reduction in area. These data are plotted } \\
\text { in the second tab. The third and fourth tabs have graphs showing the detailed sample } \\
\text { stresses as strain was increased for each sample. One of these tabs is for Alloy } 617 \text { and } \\
\text { the other is for Alloy } 800 \mathrm{H} \text {. Finally, a tab provides links to stored procedures that } \\
\text { download the data for particular samples, one of the alloys, or both alloys. }\end{array}$ \\
\hline
\end{tabular}


Table B-5. (continued).

\begin{tabular}{|c|c|c|c|c|c|}
\hline \multicolumn{3}{|c|}{ Web Page Hierarchy } & \multirow[b]{2}{*}{ Portlet } & \multirow[b]{2}{*}{ Content Type } & \multirow[b]{2}{*}{ Content } \\
\hline Level 1 & Level 2 & Level 3 & & & \\
\hline \multirow{5}{*}{$\begin{array}{l}\text { HTM } \\
\text { (High } \\
\text { tem- } \\
\text { perature } \\
\text { materials) } \\
\text { (cont.) }\end{array}$} & \multirow[t]{5}{*}{ RPV } & - & $\begin{array}{l}\text { 1. Reactor } \\
\text { pressure } \\
\text { vessel }\end{array}$ & Text & $\begin{array}{l}\text { Introductory text about characterization of steel Alloys A508 andA533 for possible } \\
\text { use in reactor pressure vessels. The set of planned test series for these materials, from } \\
\text { PLN-2803 (R. Wright, 2010), is listed. }\end{array}$ \\
\hline & & \multirow[t]{2}{*}{$\begin{array}{l}\text { Cyclic } \\
\text { tests }\end{array}$} & $\begin{array}{l}\text { 1. Intro- } \\
\text { duction to } \\
\text { cyclic } \\
\text { testing }\end{array}$ & Text & Introductory text about cyclic testing for Alloys A508 and A533 \\
\hline & & & $\begin{array}{l}\text { 2. Cyclic } \\
\text { stress-strain } \\
\text { curves }\end{array}$ & $\begin{array}{l}\text { HTML tabs } \\
\text { with links to } \\
\text { embedded } \\
\text { graphs, data } \\
\text { tables, and } \\
\text { stored } \\
\text { processes that } \\
\text { support data } \\
\text { downloads }\end{array}$ & $\begin{array}{l}\text { Three tabs with data from PLN-2803 Test Series A-29. The Alloy A508/A533 samples } \\
\text { were tested at various temperatures and strain levels. Like PLN-2804 Test Series A-20 } \\
\text { (in the "Baseline creep-fatigue testing on Ally 617" portlet under "HTM -> IHX \& } \\
\text { SG"), the first tab shows hysteresis loops, the second shows peak and valley stresses, } \\
\text { and the third is a sample-level summary of the test conditions and outcome. The } \\
\text { destructive tests continued until most of the samples fractured. The fracture initiation } \\
\text { site, location, and failure time are shown, along with the number of strain cycles } \\
\text { before fatigue damage was noted and the number of strain cycles before failure. }\end{array}$ \\
\hline & & \multirow[t]{2}{*}{$\begin{array}{l}\text { Tensile } \\
\text { tests }\end{array}$} & $\begin{array}{l}\text { 1. Intro- } \\
\text { duction to } \\
\text { tensile } \\
\text { testing }\end{array}$ & Text & Introductory text about tensile testing for Alloys A508 and A533B. \\
\hline & & & $\begin{array}{l}\text { 2. Baseline } \\
\text { strength } \\
\text { tests }\end{array}$ & $\begin{array}{l}\text { HTML tabs } \\
\text { with links to } \\
\text { embedded } \\
\text { graphs, data } \\
\text { tables, and } \\
\text { stored } \\
\text { processes that } \\
\text { support user- } \\
\text { specified } \\
\text { graphics and } \\
\text { downloads }\end{array}$ & $\begin{array}{l}\text { Four tabs with data from PLN-2803 Test Series A-15. The displays are similar to the } \\
\text { displays for PLN-2804 Test Series A-1, except that there are two strain rates for the } \\
\text { tests instead of two alloys. A summary table in the first tab provides sample data. The } \\
\text { test conditions include both the nominal strain rate and the temperature. Output } \\
\text { measures (ultimate tensile strength, yield strength, \% elongation, and \% reduction in } \\
\text { area) are tabulated; in the second tab they are plotted as a function of temperature. The } \\
\text { third tab contains graphs of the detailed sample data for the two strain rates. The } \\
\text { navigation panel on the left allows display of data for either strain rate, or display of } \\
\text { data for particular samples. An interactive plot link supports user-defined sample } \\
\text { selection for the plots. The last tab has links to stored processes that download data for } \\
\text { particular samples or for all of the samples. }\end{array}$ \\
\hline
\end{tabular}

